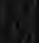




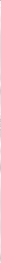

LIBAARY OF THE UNIVERSITY OF GALIFORMIA
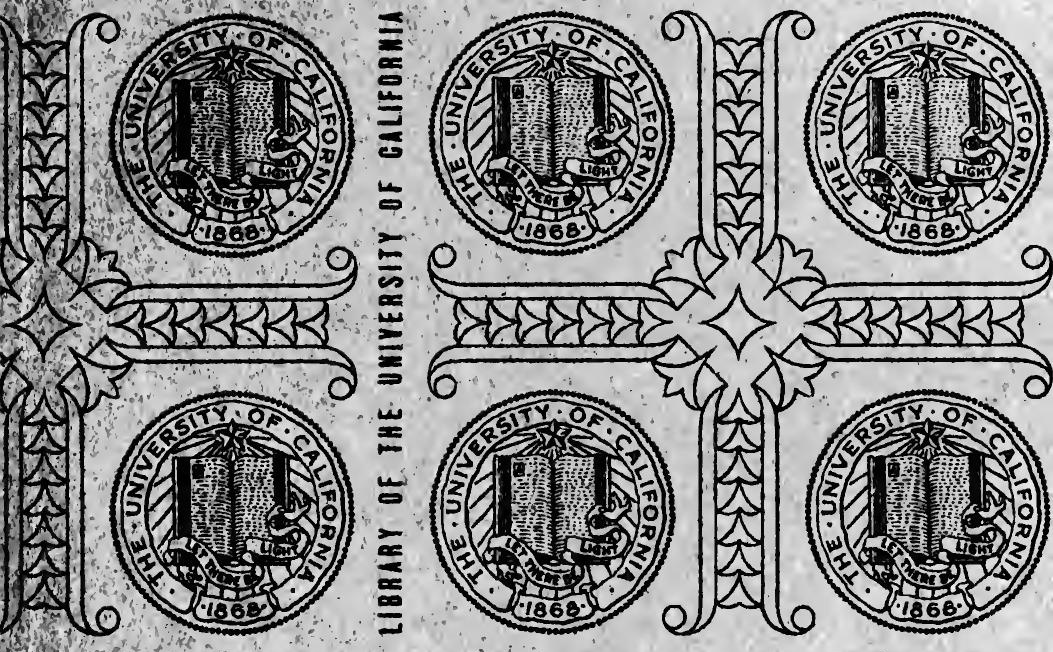

LIBAARY OF THE UMIVERSITY OF CALIFORMIA
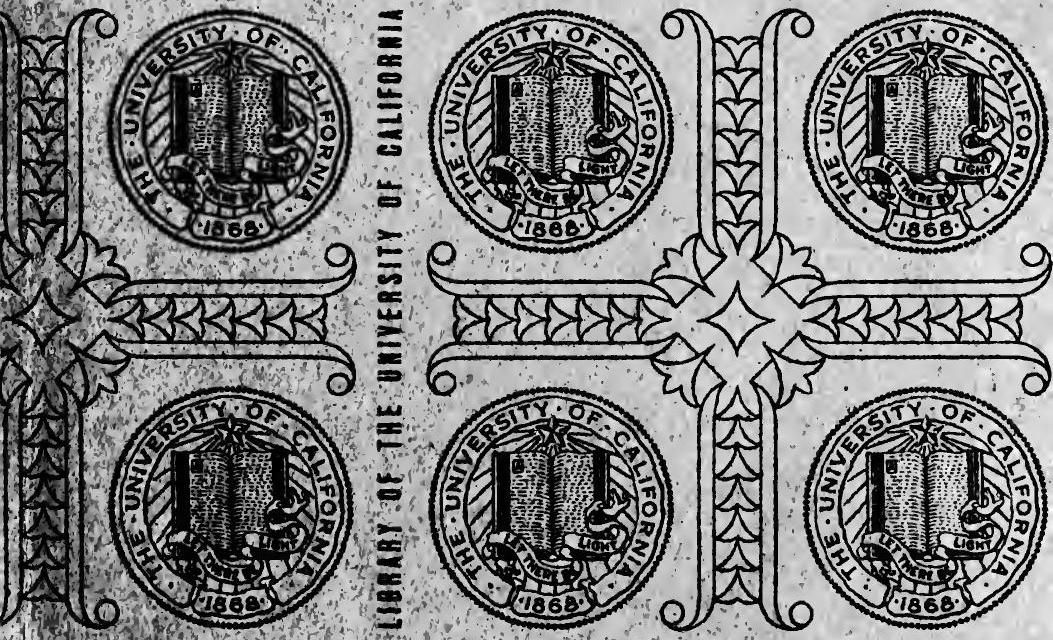



\section{Digitized by the Internet Archive in 2007 with funding from Microsoft Corporation}




\section{THE UNITED STATES}

An Experiment in Democracy

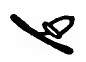





\title{
THE UNITED STATES
}

An Experiment in Democracy

\author{
By \\ CARL BECKER \\ Professor of Modern European History \\ in Cornell University
}

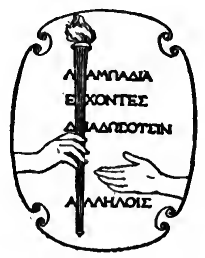

Harper \& Brothers Publishers New York and London 


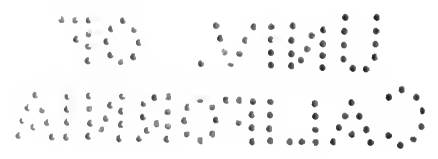

U. S. AN EXPERIMENT IN DEMOCRACY

Copyright, 1920, by Harper \& Brothers Printed in the United States of America Published August, 1920

$$
\text { a-U }
$$




\section{ACKNOWLEDGMENT}

In the preparation of this work I have been greatly aided by my former colleague in the University of Minnesota, Professor Guy Stanton Ford, whose excellent judgment and cordial assistance are an unfailing resource for for all who have the good fortune to be associated with him.

Carl Becker

Ithaca, New York

March, I5, 1920 



\section{CONTENTS}

CHAP. PAGE

I. AMERICA AND DemocracY - • • • • • . I

II. The Origins of Democracy in America - 5

III. The New World Experiment in Democracy 20

IV. Democracy and Government . . . . . 64

V. New World Democracy and Old World InTERVENTION •. . • . . • . • . . 108

VI. Democracy and Free Land . . . . . $\mathbf{4} 42$

VI1. Democracy and Slavery . . . . . . 186

VIJI. Democracy and Immigration . . . . 225

IX. Democracy and Education . . . . . 262

X. Democracy and Equality . . . . . 296 



\section{THE UNITED STATES}

An Experiment in Democracy 



\section{THE UNITED STATES}

An Experiment in Democracy

AMERICA AND DEMOCRACY

EVERYcountry is important in its own eyes and for its own people; but some countries have a wider significance, a significance for the world at large which gives them a peculiar place in the history of civilization. England, for example, has come to stand for what is roughly called political liberty;- and, being pre-eminently the founder of colonies, she is sometimes called the "mother of nations." France has never been only France, but always something European-the source and the exemplar of fruitful ideas. The United States has likewise had its meaning for the Occidental world; in its own eyes and in the eyes of Europe it has stood for the idea of democracy. "Conceived in liberty and dedi, cated to the proposition that all men are 


\section{THE UNITED STATES}

created equal," its history has had the significance of a great social experiment.

Americans themselves have commonly taken democracy for granted, but for a century intelligent Europeans were aware that popular government and social equality on such a grand scale were new things in the world. The outcome they could not regard as a foregone conclusion, but they knew that the phenomenon was well worth careful attention, since it was bound, for good or for evil, to have a profound influence upon the trend of hisitory in Europe. In the course of a hundred years many Europeans have come to observeus at first hand; and from Crèvecœur to H. G. Wells the thing that has chiefly interested them has been the character and the relative success or failure of our political and social institutions. They have endeavored to estimate, for the instruction of European readers, the form and pressure of our democracy, in order that it might serve as an example 'or a warning to the Old World.

With the exception of Lord Bryce, the most intelligent European who ever set himself the task of observing America at first hand was Alexis de Tocqueville. De Tocqueville was no apostle of democracy, but he convinced himself that it was bound to come, accepted it as one accepts the inevitable, and like a wise 


\section{AN EXPERIMENT IN DEMOCRACY}

man wished to be prepared for it. It was in order to be prepared for it that he came to America, where he thought it could be observed in its most perfect manifestation and to the best advantage.

It is not [he says] merely to satisfy a legitimate curiosity that I have examined America; my wish has been to find instruction by which we may ourselves profit. Whoever should imagine that I have intended to write a panegyric would be strangely mistaken, and in reading this book he will perceive that such has not been my design: nor has it been my object to advocate any form of government in particular, for I am of opinion that absolute excellence is rarely to be found in any legislation; I have not even affected to discuss whether the social revolution, which I believe to be irresistible, is advantageous or prejudicial to mankind. I have acknowledged this revolution as a fact already accomplished or on the eve of its accomplishment, and I have selected the nation, from those that have undergone it, in which its development has been the most peaceful and the most complete, in order to discern its natural consequences, and, if it be possible, to distinguish the means by which it may be rendered profitable. I confess that in America I saw more than America; I sought the image of democracy itself, with its inclinations, its character, its prejudices, and its passions, in order to learn what we have to fear or to hope from its progress.

This statement of De Tocqueville might be taken as representing the attitude of Europe toward America during the first century of her 


\section{THE UNITED STATES}

history as an independent nation. Intelligent Europeans have seen in America more than America; they have seen in it the image of democracy itself. Whether this image has seemed to them pleasing or menacing, they have realized that it might teach them much of what they had to fear or to hope for in the future. In its origin and in its history the United States stands for democracy or it stands for nothing. What is the character of this democracy? What were the conditions of its origin? Upon what solid or fragile foundations does it rest? What is essential in order. that it may endure? 


\section{II}

THE ORIGINS OF DEMOCRACY IN AMERICA

MANY sorts of people contributed to the 1 settlement of the thirteen English colonies which declared their independence of Great Britain on July 4, 1776. Men of all classes, from the noble to the jailbird, were among the first English immigrants in the seventeenth century; but for the most part the settlers were neither the outcasts nor the favorites of fortune, but the moderately well-to-do-lawyers, doctors, merchants, shopkeepers, small landowners, and peasants. The motives which inspired these people to try their fortunes in America varied with the individual, as well as with the region in which they settled. Some came in a spirit of adventure, others to mend their fortunes or escape the consequences of crime or poverty. Certain colonies, such as Virginia, were founded chiefly by men who sought better economic opportunities; while others, such as Massachusetts, were founded by men whose main 


\section{THE UNITED STATES}

aim was to erect in the New World that ideal commonwealth which they despaired of ever seeing in Europe. However varied and intermingled these motives may have been, they may all be included in one motive, which was the desire for more freedom and a better opportunity. Speaking generally, therefore, it may be said that the founding of the English colonies, which afterward became the United States of America, was an idealistic enterprise - the work of discontented men who sought in the New World a freedom which was denied to them in the Old.

In the New World they found much freedom of a certain kind. They found freedom from tradition, and from the legal and conventional restraints of civilized society. In America they found no pope and no king, no noble lords levying toll upon the land, no Church exacting fees from the poor as the price of salvation. In America men found all the freedom of Nature. Yet Nature imposes her own constraints. In this wilderness to which they came the early settlers found that liberty was the reward of those who seek out and obey the harsh and unproclaimed laws of the physical universe. For many years the only liberty which they had was the liberty to exist, if, perchance, they could manage to do so. Thousands perished, but the hardy survived; the 


\section{AN EXPERIMENT IN' DEMOCRACY}

hardy and the adaptable, the resourceful, the inventive, the stubbornly persistent, those with a certain iron hardness in their nature, those with the indomitable will to conquerthese survived and won the freedom of the New World.

While the New World of America was no lotos-land to be enjoyed without effort, the difficulties to be overcome were different in the North and in the South. There was every variation in physical environment from the meager soil and bitter winters of New England to the rich bottom-lands and almost tropical heat and miasmic atmosphere of South Carolina. Besides the difference in soil and climate the various colonies were settled by a somewhat different class of people, and in some cases by people who came for quite different purposes. It is therefore in part due to physical reasons and in part due to moral reasons that certain characteristic differences came to distinguish the institutions and customs of the New England, the Middle, and the Southern colonies.

The people who came to Virginia were mostly well content to establish there the institutions of old England, to reproduce its class divisions, to perpetuate its social customs. But it was found that the most profitable thing to raise in Virginia was tobacco; 


\section{THE UNITED STATES}

and in spite of every effort to prevent it, tobacco became the one important staple crop of the colony. Thus it happened, contrary to expectation, that Virginia was settled, not in compact towns on the English model, but in great and widely separated farms or plantations, strung along the river-banks where the rich bottom-lands were. The plantation was managed by the owner or "planter," and worked at first by "servants"-men who had sold their services for a term of years in order to pay the cost of their transportation to America-and afterward by negro slaves. Towns did not grow up in Virginia, because the plantation was a kind of economically selfsupporting community in itself, and because the tobacco could be most easily shipped directly from the planter's own docks on the river-front. Thus there were in Virginia only two classes, the planters and their subject servants and slaves. Virginia was in fact a landowning aristocracy, without nobility or merchant class, or any considerable small peasant farming class; and the other Southern colonies, except North Carolina, were on the whole similar to Virginia in these respects.

The New England colonies differed widely from Virginia, both in the motives which led to their settlement and in the economic characteristics of the communities which were in fact 


\section{AN EXPERIMENT IN DEMOCRACY}

established there. Massachusetts, the principal New England colony, was settled by Englishmen who were not content to re-establish in America the institutions that existed in England. These Puritans-so called because they wished to "purify" the English Church from "popish practices"- came to America primarily to establish a society which should be at once State and Church-a "due form of government, as well civil as ecclesiastical"; an ideal or Bible commonwealth which should be pleasing in the sight of God and conformable to His law. In Massachusetts, and this was true of New England as a whole, the unit of settlement was thus the town and the parish, two things intimately related; and this type of settlement was suited not only to the ideal purposes of the settlers, but also to the economic conditions which made Massachusetts a small farming country given up largely to the raising of grain and live stock. Every New England colony, therefore, was at first a collection of little agricultural villages or townships, where the people built their houses around the church, which was the center of community life, and where they distributed their land and managed their affairs in little democratic assemblies of freeholders known as the town meeting.

Between the New England and the Southern 9 


\section{THE UNITED STATES}

colonies lay the Middle colonies of New York, Pennsylvania, New Jersey, and Delaware. They were in origin the least English of the Colonies. New York was originally settled by the Dutch, from whom it was conquered by England in 1664. Pennsylvania, although founded by the Englishman, William Penn, was from the beginning a refuge for the oppressed of continental Europe as well as for the English Quakers who followed Penn to the New World. More composite in their population, the Middle colonies united in some measure the characteristics of the New England and the Southern colonies; in respect to their origin, the religious motive was more prominent than in the South, but less so than in New England; the small farm was the characteristic economic feature, but the large estate was common in New York; the unit of local government was neither the town, as in New England, nor the county, as in the South, but a combination of town and county.

By the middle of the eighteenth century the population of the Colonies had reached a million and a half, and their increase in wealth was even more marked. The early eighteenth century was a golden age in agriculture and commerce, and in this prosperity the Colonies shared. In nearly every colony there came to be a small group of landowning and commer- 


\section{AN EXPERIMENT IN DEMOCRACY}

cial families of considerable wealth, closely interrelated by marriage, and forming a little colonial aristocracy which largely controlled the government and legislation of the colony. Rather sharply separated from this aristocracy of "best families" was the class of the "humble folk" - the small farmers, the artisans and mechanics in the towns, and the servant and slave population-who had but little political or social influence. In every colony there was an assembly of representatives chosen for the most part by the property-owners, and largely dominated by the coterie of wealthy families. Aside from the legislative assemblies, which passed laws mainly in the interest of the classes that controlled them, there was in each colony a governor, and in most colonies an executive council which was also usually an upper legislative chamber; but the governors in every colony, except Connecticut and Rhode Island, and in most cases the executive council also, were appointed by the British government and were supposed to represent the interests of the British Empire just as the assemblies were supposed to represent the interests of their particular colonies.

The interests of the British Empire chiefly centered in the trade laws, those regulations which required the Colonies to export certain staple products, such as sugar, tobacco, indigo, 


\section{THE UNITED STATES}

and naval supplies, to Great Britain or to a British colony, and which likewise required the Colonies to import most of the manufactured commodities which they needed from Great Britain. The trade laws were not, for the most part, very serious burdens, for the British merchant could not profit by the ruin of the colonial trader, and in the long run regulations prejudicial to either were not very rigidly enforced. The burden of the trade laws fell chiefly upon the poor in England and in the Colonies, since the mercantile system was designed not so much for the advantage of England at the expense of the Colonies, but rather for the special advantage of the upper classes in both countries, the merchants and landowners in England and the Colonies alike.

Under these circumstances, the ruling classes - landowners, merchants, and moneyed men -in the Colonies as well as in England, were greatly interested in the defense and the extension of the Empire. In pursuit of this object England fought a number of wars in Europe during the eighteenth century, mainly against France; and, inasmuch as the English colonies in America were in close contact with the French settlements to the north and west, every war between England and France in Europe was necessarily a war between the English and French colonies in America. What 


\section{AN EXPERIMENT IN DEMOCRACY}

is known in American history as King William's War was but the American counterpart of the war of the League of Augsburg (168597); Queen Anne's War was the counterpart of the War of the Spanish Succession (I70I-I3); King George's War was the counterpart of the War of the Austrian Succession (1740-48); and the French and Indian War was the counterpart of the Seven Years' War (1756-63). In America all of these wars were in fact "French and Indian" wars; in all of them the colonists were expected to defend themselves against the French and against their numerous Indian allies, on land, while the British government furnished them protection on the sea. Every colonial war was a considerable expense to the Colonies; but it was maintained that the defense and extension of the Empire was an advantage to the Colonies no less than to Great Britain.

Of all the colonial wars of the eighteenth century, the most important was the last one, the French and Indian War (I754-63), which was the American counterpart of the Seven Years' War in Europe. In fact, the war broke out in America before it did in Europe, and the immediate cause of the war was the dispute between the French and English in respect to their relative rights to the 


\section{THE UNITED STATES}

territory west of the Alleghanies. The English had always claimed this territory as the legitimate extension of the lands which they occupied on the seacoast; the French claimed it by the right of discovery and occupation. The most direct entrance to the rich lands west of the Alleghanies was by way of the upper Ohio River, and it was the attempt of the French and English to fortify and hold the upper Ohio at the place where the present city of Pittsburg stands that precipitated the French and Indian War. After a long and difficult struggle, the English won, both in Europe and in America. By the Treaty of Paris of 1763 the French were practically expelled from North America, and England acquired all of her possessions east of the Mississippi.

The year i763, which marks the close of this seven years' conflict, was an important date in the history of the world. In Europe the war had taken the form of an attempt to destroy the rising power of Frederick the Great. That object was not attained, and the chief results of the war were, therefore, two: it assured the ultimate ascendancy of Prussia over Austria in Germany, and it assured the maritime and commercial ascendancy of England over France in India and America. Yet the Treaty of Paris, which seemed to open the way for a great extension of the British 


\section{AN EXPERIMENT IN DEMOCRACY}

Empire in North America, was in fact the prelude to the loss of its chief possessions there; for with 1763 we may date the beginning of that long conflict between the Colonies and the mother country of which the outcome was the establishment of the United States as an independent nation.

The war itself laid the foundation for this conflict. During the war the Colonies levied and equipped about twenty-five thousand troops, and these troops, although they could not alone have driven the French out of Montreal and Quebec, gave essential assistance in achieving that end. The Colonies had good reason, therefore, to feel that they had done their full part in expelling the French from North America; and they were much inclined to think that for the future, especially as the danger from France was now once for all removed, they could easily defend themselves without any British aid at all. The general effect of the French and Indian War upon the Colonies was one of emancipationit gave them a sense of power and independence such as they had never known before.

This feeling of emancipation was due not only to the fact that the Colonies had aided in winning the war, but also to the fact that for the first time they had acted together for a common end. The Colonies had always 


\section{THE UNITED STATES}

been noted for the spirit of jealousy and suspicion which characterized their dealings with one another. Puritan New England had looked askance at her neighbors because of their religious beliefs and practices, while the Virginia and South Carolina planters, and the wealthy merchants of New York, who copied the manners and the dress of the English "gentleman," made sport of the grave manners and precise speech of the solemn NewEnglanders. In 1760 Benjamin Franklin wrote that no one need fear that the Colonies would "unite against their own nation, which protects them and encourages them, with which they have so many ties of blood, interest, and affection, and which 'tis well known they all love much more than they love one another." Intercolonial jealousy and suspicion - the spirit of provincialism or particularismwas indeed still very strong after the war, and for many generations it was to play a great part in the history of the United States; but although the French and Indian War did little or nothing to bring about a formal union of the Colonies, it led them to realize that they could unite if they wished to do so, and that they had, after all, much in common, which ought to make them wish to do so. The men from Massachusetts and Pennsylvania and Virginia, who had been brought together and 


\section{AN EXPERIMENT IN DEMOCRACY}

who had fought side by side with the British regulars during the war, came to realize as never before that these Englishmen were somehow different from the colonials, and that a Massachusetts man was, after all, much more like a Virginian than either was like the Englishman. The French and Indian War, in fact, greatly strengthened the sense of intercolonial solidarity. Men began to think of themselves as in some sense Americans and not simply as Virginians or Massachusetts men; they thought of themselves as BritishAmericans, and to think of themselves so was to be aware that there was something more fundamental than mere geographical location which separated Americans from British. In a vague and intangible way the conception of an American nation was beginning to take form.

The feeling of intercolonial solidarity was strengthened by the rapid growth of the Colonies in wealth and population. Some years before, Franklin had pointed out the fact that the population of the Colonies doubled every twenty years, and on account of the immense stretches of free land it would continue to do so for an indefinite future. On the other hand, no European country had ever attained such a rate of increase, and during the last hundred years the population of England had not doubled once. From these 


\section{THE UNITED STATES}

facts it seemed reasonable to suppose that within the next hundred years the center of wealth and population of the British Empire would be in America rather than in Europe. Furthermore, on account of this increase in population, the Colonies were every year becoming more important to England as markets for her manufactured goods. Thus at the moment when the Colonies were beginning to feel strong enough to get along without the protection of Great Britain, they were also coming to feel in some measure that Great Britain could not very well get along without them.

Not only did the French and Indian War change the attitude of the Colonies toward Great Britain, it also changed the attitude of Great Britain toward the Colonies. For seven years Great Britain had been fighting not only in America, but in Europe and in India and on the sea-in the "four parts of the world," as Voltaire said. Within seven years, as a result of these wars for the defense and extension of the Empire, the public debt had doubled. Much of this debt had been contracted for maintaining the English fleet and army in America, and Englishmen were inclined to overlook the assistance rendered by the Colonies and to take to themselves the credit for the expulsion of the French from Canada-without the British troops, they 


\section{AN EXPERIMENT IN DEMOCRACY}

were inclined to think, the colonists would have found themselves subjugated to the Bourbon despotism. It seemed only right, therefore, that the Colonies should contribute something to the defense of the Empire in return for the protection which had been extended to them. On account of the great expansion of the British possessions in America, the British government felt that it was necessary to retain a part of the British army in the Colonies as a check against the Indians and in order to assure an effective control of Canada, and it was generally thought in England that the Colonies could not reasonably object to paying some tax or contribution in partial support of this army which was to be stationed among them for their own protection.

Thus, in 1763 , the very time when the Colonies were acquiring a new sense of strength and independence, the British government was preparing to adopt measures for the closer integration of the Empire and for imposing upon the Colonies some part of the burden of imperial defense. The attempt of the government, in $1764-65$, to lay taxes for this purpose was the beginning of ten years of controversy and strife which led finally to the American Revolution and the independence of the Thirteen Colonies. 
THE NEW WORLD EXPERIMENT IN DEMOCRACY

\section{I}

IN I760, three years before the Peace of Paris was signed, George III became King of England. This was an event of great importance in the history of England and of the United States, on account of two political objects which the new king pursued with stubborn persistence during the first twenty years of his reign. In the first place, George III was always in favor of the policy of taxing the Colonies and of subjecting them to the authority of the British Parliament. In the second place, he was determined to make the Ministers carry out the policy of the king rather than a policy imposed upon the king by the Parliament. The twofold aim of George III was to establish the supremacy of the Parliament over the Colonies, and to establish the supremacy of the king over the Parliament; and these two vital questions, 


\section{AN EXPERIMENT IN DEMOCRACY}

the question of colonial rights and the question of parliamentary government in England, were bound up one with the other, inasmuch as the success of the king in achieving the one aim was likely to result in his achieving the other aim also.

This does not mean, as is often supposed, that all those who opposed the king's scheme of breaking away from the control of Parliament also opposed the taxation of the Colonies. In 1765 nearly every one in England who thought about the matter thought it only right that the Colonies should pay taxes in their own defense, and very few regarded it as unjust or illegal for Parliament to levy those taxes. The famous Stamp Tax was passed in 1765 , after a year's notice, with scarcely any opposition either in Parliament or out of it. Indeed there was but little interest in the matter, because no one supposed that there would be any serious objection. Edmund Burke said that he never listened to a more languid debate; and Horace Walpole, who afterward became a rabid supporter of the. Colonies, mentions the passage of the Stamp Act as one might mention any unimportant act of legislative routine. At the time no one realized that this act would lead to controversy, to strife, and finally to revolution and the disruption of the Empire. 


\section{THE UNITED STATES}

Such complete misunderstanding of the importance of the Stamp Act was due to the significant fact that whereas nearly every one in $\mathrm{E} g \mathrm{~g}$ d thought the law a just and reasonabl one, nearly every one in America thought it an unjust and an unreasonable one. What was the caus of this remarkable difference in the point of view of the two groups of Englishspeaking peoples? The explanation has sometimes been that the colonial leaders used this opportunity to carry out a malign and deliberately conceived conspiracy to precipitate a rebellion in order to win political independence. But there is slight evidence in support of this idea. In 1765 practically all Americans were proud of being British-Americans, they gloried in the greatness of little old England, and they looked forward with pride to the great rôle which the British Empire would play in the future history of the world. Very few colonists at that time dreamed of independence, or thought it possible for the Colonies to be happy or prosperous except as parts of the Empire. In the desire to preserve and to strengthen this Empire, both English. men and Americans were agreed; but they differed radically in their ideas of how the Empire ought to be organized and governed, and it is this difference which explains why the former thought the Stamp Act just and 


\section{AN EXPERIMENT IN DEMOCRACY}

reasonable, while the latter thought it unjust and unreasonable.

In the eighteenth century English gavernment, and to a large extent Englion w p ion in political matters, was controlled by a fally small and a fairly selfish landowning and commercial oligarchy; and the compacence and egoism of this oligarchy were never greater than just after the Seven Years' War, when all the world was fearing or admiring the tremendous success of Great Britain. Naturally enough, therefore, the average Englishman felt that this Empire, about which the great Pitt had talked so much, was the result of the virtues and the sacrifices of England, and that as it had been created so it must necessarily be held together by the force of British arms and of British laws. Apart from such control, the average Englishman was apt to say, India and the American Colonies would have been subjected to the despotism of the French kings; and what could be more reasonable, therefore, than to suppose that the defense and the development of the Empire must be undertaken by the only supreme power there was-namely, the British Parliament. If every part of the Empire should be allowed to do as it liked, there wouldn't be any Empire very long, and nothing but a selfish desire to escape their fair share of the 


\section{THE UNITED STATES}

burden of defense could lead the Americans to object to so reasonable and moderate a tax as the Stamp Tax.

The American colonists regarded the Empire in a somewhat different light. They knew very well, what the Englishman was likely to forget, that in the seventeenth century the Colonies had been established without much aid from England, in some cases by people who had been driven out of England in order to escape religious or political oppression; and they were aware that if the English government had neglected the Colonies in the seventeenth century and had allowed them to do very much as they liked, it was because they were not regarded as of great importance. The Americans felt also that the new interest in the Colonies which the English government was now exhibiting was due to the fact that the trade of the Colonies was becoming supremely important to the commercial and landowning aristocracy of England. As for the conquest of Canada, they felt that they had done even more than their share, a fact which the British government itself recognized by repaying to them a part of the money which they had raised during the war. In a word, the Americans felt that whatever importance the American Colonies had as parts of the Empire, whatever economic or military or polit- 


\section{AN EXPERIMENT IN DEMOCRACY}

ical value they possessed, was due to the labor and the sacrifices of the colonists themselves, who therefore deserved quite as much credit for building up the wonderful British Empire as the people of England.

The fundamental notion of Americans was admirably expressed by Benjamin Franklin in 1755 :

British subjects, by removing to America, cultivating a wilderness, extending the domain, and increasing the wealth, commerce, and power of the mother country, at the hazard of their lives and fortunes, ought not, and in fact do not thereby lose their native rights.

By their native rights, Americans meant the traditional right of Englishmen to govern and tax themselves in assemblies of their own choosing. Englishmen had such an assembly in Parliament, but the Colonies were not, and in the nature of the case could not well be represented in Parliament; but they had now, and had always had, their own assemblies by which they had hitherto governed and taxed themselves. These assemblies they wished at all hazards to keep. It was through these assemblies that they had raised the money to support the Empire in the last war against France, and they were quite willing in the future to raise their fair share of taxes for the support of the Empire; but they wished 


\section{THE UNITED STATES}

to raise these taxes through their own assemblies in their own way. If the Parliament could levy and collect a Stamp Tax, it could levy and collect any and all taxes, and it could regulate the powers of the colonial assemblies or abolish them altogether. The right of Parliament to tax the Colonies in fact involved the right to abolish colonial selfgovernment; and fundamentally, therefore, the Colonies were contending for the right of self-government.

In defense of this right the colonists resisted the Stamp Tax. All classes refused to use the stamped papers; in many cases the stamps were destroyed by mobs; and the merchants bound themselves not to import commodities from England until the act should be repealed. Partly on account of opposition in the Colonies, partly on account of the pressure from the English merchants, who complained that their business was being ruined, the Stamp Act was repealed in $\mathbf{1 7 6 6 .}$ But the next year, after a change of Ministry, certain duties known as the Townshend duties were laid on the importation of tea, glass, painters' colors, and paper. The colonists had claimed that the Stamp Tax was unconstitutional because it was an "internal" tax; but now they abandoned the distinction between internal and external taxes and objected 


\section{AN EXPERIMENT IN DEMOCRACY}

to the levying of any taxes whatever, including import duties intended to raise a revenue. After three years of controversy and strife, of rioting and of restrictive non-importation agreements, the British government again yielded and repealed all of the duties save the threepenny duty on tea, which was maintained, not for the revenue which it would bring in, but as an assertion of the right of Parliament to levy taxes on the Colonies.

Although the Colonies insisted that the duty on tea was unconstitutional, the controversy largely subsided during the years from I 770 to I773. In the latter year, however, the old dispute was revived by a resolution of Parliament giving to the East India Company a practical monopoly of the importation of tea into the Colonies. Taking advantage of this opportunity to gain control of a very profitable colonial business, the company sent over four cargoes of tea billed to the four ports of Boston, New York, Philadelphia, and Charleston. The Boston shipment arrived first, in the fall of 1773 , but when it was attempted to land the tea, a crowd of men disguised as Indians boarded the ship and threw the tea into the harbor. In New York and Philadelphia the tea was sent back to England, and at Charleston it was stored in the basement of the custom-house. In reply to these 


\section{THE UNITED STATES}

acts, particularly to the destruction of the tea at Boston, the British government decided to make a final test of the authority of Parliament. By overwhelming majorities the Parliament passed what were known as the Coercive acts, one of which suspended the Massachusetts government and placed the colony practically under military rule, while another closed the port of Boston until the town should make compensation to the East India Company for the loss of its property. As the king said, "The die is now cast; the colonists must either submit or win complete independence." This was true, and, now that the issue was so clearly one of legislative independence and not merely one of taxation, the colonists gradually changed their argument once more, and from this time on were inclined to deny not merely the right of Parliament to tax the Colonies, but the right of Parliament to legislate for them at all.

It was on this theory that the war was waged. According to this theory, as the colonists finally elaborated it, the Empire was a federation of states rather than a unitary state; and just as England and Ireland and Hanover each had its own government, so the American Colonies must have their own governments, all of these separate countries and governments being united under the king 


\section{AN EXPERIMENT IN DEMOCRACY}

without being subject to the Parliament. The English Parliament, according to this theory, would be primarily the legislature for England and Scotland; but on account of its central and imperial position it would also exercise a directing and supervising control of matters of purely imperial concern, such as international relations and general commercial regulations; but it would have no control whatever over the local legislative concerns of the Colonies any more than over the local concerns of Hanover. The famous Declaration of Independence was constructed on this theory. It does not mention Parliament; the charges of tyranny and oppressir. are all directed against the king, on the ground that the Colonies could declare their independence of the king only, since the king was the only authority to which they had ever been legally subject.

The battle of Yorktown made it clear to all, even to the stubborn king himself, that the attempt to subject the Colonies to parliamentary control must be abandoned. But in abandoning this object the king had also to forgo the attempt to establish royal supremacy over Parliament. In a very real sense the victory at Yorktown in 1781 not only established the independence of the United States, but contributed to the triumph 


\section{THE UNITED STATES}

of the principle of parliamentary government in England as well.

From his accession, in $\mathbf{1 7 6 0}$, to the end of the Revolution George III steadily labored to undermine the principle of the responsibility of Ministers to Parliament. His ideal of government was not far different from that of the rulers of modern Germany: it was the king's duty to rule his people, to rule them wisely and well in a paternal spirit; it was the duty of the people to submit dutifully to this paternal wisdom; as for the Parliament, that was a body of representative men whose business it was to give advice to their master so that he might indeed rule wisely, but never to force its advice upon him. George III would therefore have Ministers of his own choice who were entirely responsible to him and not to the Parliament; he would have Ministers who, because they were chosen by him from all parties, would be subject to no party and would be able, therefore, to give him disinterested advice. For twenty years the king worked steadily to realize this type of benevolent despotism in England.

It is not likely that the king could in any case have succeeded. Nevertheless, his object was not an impossible one. At that time the principle of ministerial responsibility to Parliament was by no means firmly established 


\section{AN EXPERIMENT IN DEMOCRACY}

in English political practice, and the conditions of English politics were so undemocratic and in many respects so corrupt that there was something to be said in favor of the king's contention. The English Parliament in the eighteenth century was a representative body, but it was not a democratic body. It really represented those great landowners and merchant princes who were able, through their wealth and social influence and by virtue of a peculiarly inequitable system of elections, to control in large measure the return of members to Parliament. The political leaders who looked out for the interests of these classes were divided into a number of groups or "factions." They all called themselves "Whigs" because the term "Tory" had fallen into disrepute since 1714, when Lord Bolingbroke and other Tories had opposed the accession of the Hanoverian dynasty and had intrigued to bring back instead the exiled Stuarts. From I7I4 to 1760 , therefore, the government of England fell into the hands of the Whigs; and at the time of the accession of George III, in $\mathbf{1 7 6 0}$, the various Whig factions-the Bedford Whigs and Pelham Whigs and Grenville Whigs-had come to think of government as a kind of vested right to be enjoyed by them forever. And in particular they had come to think of the king's Ministers as men who 


\section{THE UNITED STATES}

must be the responsible leaders of Parliament, as men who must adopt policies which could be carried through Parliament.

Now George III was not willing to submit to ministerial, that is to say, to parliamentary, control. George III was the first of the House of Hanover who could speak the English language as his native tongue, and he was the first to be more interested in his English possessions than in his Hanoverian possessions. "Born and bred an Englishman," he said, "I glory in the name of Briton." He not only gloried in the name of Briton, he gloried also in the name of king; and from the first day of his reign he was determined to be a real king, to formulate his own policies, and to destroy the controlling power of the great Whig families. It must be confessed that there is not much to be said for the Whig factions, or, with exceptions, for their leaders. Such men as the Duke of Newcastle, the Duke of Bedford, George Grenville, or Charles Townshend were more intent upon advancing their own political interests, or in circumventing the intrigues of a rival faction, than they were in advancing the interests of the nation or defending or promoting the cause of free government. The famous William Pitt, a great liberal and a friend of the right of the Colonies to tax themselves, was nevertheless 


\section{AN EXPERIMENT IN DEMOCRACY}

as hostile to the Whig factions as the king himself, and as willing to see them destroyed. But the king aimed to do more than to destroy the Whig factions; he aimed to make the king independent of Parliament - to restore the powers and prerogatives which the kings had enjoyed before the Revolution of 1688 . Thus it happened that in resisting the king, and in trying to force their Ministers upon him, the corrupt Whig factions, whatever the motive may have been which inspired their action, were really fighting for the principle of representative government against the principle of royal supremacy.

This conflict between the king and the Whig factions went on during the first twenty years of the new reign; and as time passed it became clear that the question of parliamentary as against royal control in the English government was bound up with the question of the success or failure of the Colonies in their struggle for self-government. The number of men who supported the Colonies was not great, although they were often men of the greatest ability, such as Pitt and Burke and Fox; and when the Colonies declared their independence many men in England who had formerly supported them now rallied to the support of the government's policy. Pitt himself was one of these; and in fact it was the revolt of 


\section{THE UNITED STATES}

the Colonies which temporarily rallied the great majority of Englishmen to the support of the king and enabled him to build up a "King's Party" in Parliament that steadily carried the policies of his Minister, Lord North, who in turn took his instructions from the king. During the American war, which was the period of the Ministry of the subservient Lord North, the king was thus able to attain his object of subjecting the Parliament to the royal will. But it was precisely because the revolt of the Colonies had thrown all power into the hands of the king that the maintenance of this power depended upon the outcome of the Revolution. If the king could subjugate the Colonies, his system of government would be justified; if the Colonies won independence, such a disaster to the Empire would entirely and forever discredit his system of government. This, in fact, came to pass; the defeat of Cornwallis at Yorktown sealed the fate of Lord North's Ministry, and with the fall of Lord North the subjection of Parliament to the royal will was at an end.

\section{II}

The American Revolution was thus primarily a struggle between the Colonies and Great Britain over the question of self-government 


\section{AN EXPERIMENT IN DEMOCRACY}

-a struggle which was bound up with the question of royal as against parliamentary government in England, of popular government against a possible autocracy. But there was also another phase of the Revolution, and that was the struggle within the Colonies themselves between the little commercial and landowning aristocracies that had hitherto governed the Colonies and the "people," the unfranchised "humble folk," who now were coming to demand a measure of political equality. This struggle runs throughout the period of the controversy with Great Britain from 1765 to 1776 ; and while it was somewhat diminished during the period of the war itself, it broke out again with renewed force after the war was over. In fact, the American Revolution was not only a movement for national independence from Great Britain; it was also a movement for the democratization of American society and politics-a movement which has continued from that day to this and which is the central theme of our history.

In 1765 the right of voting in the American Colonies for members of the colonial assemblies was in general restricted to those who possessed property, or met certain educational or religious tests. In most colonies a majority, and in all a considerable minority, of the adult 


\section{THE UNITED STATES}

male citizens were disfranchised. Besides, the methods of naming candidates and of voting were such as to place a determining influence in the hands of a small coterie of wealthy families - the so-called "best families" of the province. These best families, together with the governors, who were mostly appointed from England and frequently from among these very families, made a very distinctive and powerful upper class -a wellintrenched aristocracy which was the real governing force in each colony. In Virginia and South Carolina this class was composed of the great tidewater planters, whose extensive fields of tobacco, rice, and indigo were cultivated by means of negro slaves. In the Middle colonies there were not only the great landowners, whose estates were cultivated mainly by tenant labor, but also the wealthy commercial families of the cities of New York and Philadelphia. In New England there were fewer great estates and the small freeholders were more numerous; but there also a political and social aristocracy had come into existence-descendants of the old official and clerical leaders closely allied with families that had gained prominence in law or commerce.

Sharply distinguished from these "gentlefolk," in dress and manners as well as in 


\section{AN EXPERIMENT IN DEMOCRACY}

social and political influence, was the great mass of the population-artisans and laborers, tenant and small freehold farmers. In the Middle and Southern colonies this distinction had come to have a territorial as well as a social and economic basis. In Virginia the poorer classes had moved "west" beyond the first falls of the rivers, into the piedmont or "up-country," where land was plentiful and cheap; while in Pennsylvania German and Scotch-Irish immigrants in great numbers had settled in the interior counties and from there had followed the valleys southward into the Virginia and Maryland upcountry and even as far south as the Carolinas. In this back-country the soil was not adapted to tobacco or rice. Here there were no great estates, no slaves, and few "servants," no houses with pretensions to architectural excellence, no leisured class with opportunities or inclinations for acquiring the manners or the tastes of the "gentleman." Here every man earned his bread by the sweat of his brow, manners were rude and primitive, institutions were simple, men lived close to the soil, equality was a fact, and freedom was limited only by the stubborn resistance of nature.

The conflict between the interests and ideals of these two classes and these two regions was already beginning when the controversy be- 


\section{THE UNITED STATES}

tween the British government and the Colonies began; and from the first the two issues became more or less identified. This was strikingly the case in Virginia in respect to the resolutions to be adopted in protest against the Stamp Act. In the session of the House of Burgesses of 1765 the old leaders of the tidewater region, who had always managed the colony, were opposed to adopting any resolutions at that time, since they had already, in 1764 , drawn up a mild protest against the passage of the act. But there was present at this session the famous orator and tribune of the people, Patrick Henry, who had recently made a name for himself by exposing the shady actions of the treasurer, John Robinson, a prominent member of the aristocracy. This was equivalent to challenging the supremacy of the little group of tidewater planters, who had come to look upon the management of the colony as their vested duty. The episode had given Patrick Henry a great name in the province, and had got him a considerable following among the young men and small planters throughout the province, and especially in the back-country where he was born and raised and which he represented. In this session of 1765 Henry took the lead against the conservatives in introducing and passing a set of resolutions which 


\section{AN EXPERIMENT IN DEMOCRACY}

protested much more vigorously against the Stamp Act than the old leaders desired.

The episode was afterward described by Thomas Jefferson, at that time a young law student, who watched with interest the doings of the Virginia House of Burgesses.

Mr. Henry moved and Mr. Johnston seconded these resolutions successively. They were opposed by Messrs. Randolph, Bland, Pendleton, Wythe, and all the old members, whose influence in the House had, till then, been unbroken. They did it, not from any question of our rights, but on the ground that the same sentiments had been, at their preceding session, expressed in a more conciliatory form, to which the answers were not yet received. But torrents of sublime eloquence from Henry, backed by the solid reasoning of Johnston, prevailed. The last, however, and strongest resolution was carried but by a single vote. The debate on it was most bloody. I was then but a student, and stood at the door of communication between the House and the lobby; . . . and I well remember that, after the members on the division were told and declared from the chair, Peyton Randolph came out at the door where I was standing, and said, as he entered the lobby, "By God! I would have given five hundred guineas for a single vote."

This was only the beginning of a long struggle between the old leaders, endeavoring to maintain their social and political predominance in the province, and the young radicals, backed by the people of the back-country, of 


\section{THE UNITED STATES}

whom Patrick Henry and Thomas Jefferson and Richard Henry Lee were the leaders. In every stage of the conflict with Great Britain the old leaders showed themselves more cautious and conservative, the radicals more vigorous and uncompromising, in asserting the rights of the Colonies and in advocating measures of resistance. But the difference between the two parties went deeper. The radicals wanted to democratize the social and political institutions of Virginia, while the old leaders wanted to maintain their supremacy; and when the breach with England finally came and a new constitution had to be formed, Jefferson and his associates attempted to make the new constitution strictly democratic, with universal manhood suffrage, the abolition of entail in land and of primogeniture, and the disestablishment of the Anglican Church. Jefferson even went so far as to talk of the abolition of slavery. The democrats in Virginia were not able to get everything they wanted; but they accomplished much. They not only pushed the old aristocracy into the Revolutionary War, but they established a far more democratic government in Virginia than the old leaders of the colony would have established if it had been left to them. It was the declaration of rights prefixed to this constitution that was translated and circulated in 


\section{AN EXPERIMENT IN DEMOCRACY}

France, and that became in some degree a model for the famous French Declaration of the Rights of Man and the Citizen.

Very similar was the conflict in Pennsylvania between the Scotch-Irish and Germans of the interior and the Quaker-merchant aristocracy of Philadelphia. The people in the frontier counties complained that the apportionment of representatives, the money system, and the organization of the courts of justice were all devised to benefit the Quakers and merchants and to perpetuate their power. "We apprehend," so runs a petition from the German and Scotch-Irish counties of the interior, "that as freemen and English subjects we have an indisputable title to the same privileges and immunities with his Majesty's other subjects who reside in the counties of Philadelphia, Chester, and Bucks." The Scotch-Irish and Germans of the interior counties, together with the mechanics and artisans of Philadelphia, made the strength of the radical party. The frontier counties in Pennsylvania, like the frontier counties in Virginia, were strong partizans of the struggle against England, partly because they had no reason to like England, but partly because they felt that the argument in favor of the rights of the Colonies against England could be used equally in support of their own rights against 


\section{THE UNITED STATES}

the privileges of the merchants and Quakers in Pennsylvania. In $1775-76$, when the first constitution of Pennsylvania was established, the essential issue was between the Scotch-Irish radicals, who wanted a strictly democrat constitution, and the eastern men, who wished so far as possible to preserve their own supremacy.

Nowhere was this conflict between the popular and the aristocratic classes more marked than in Massachusetts. The most influential man in Massachusetts at that time was Thomas Hutchinson, whose family had been prominent in Boston since the founding of the colony. He was a man of excellent education and of great ability, and in $177 \mathbf{I}$, at the age of sixty, had held nearly every elective and appointive office in the province. He was also a man of wealth and related to most of the influential families of wealth in Massachusetts - the most prominent member of the Boston "aristocracy" which had long governed the Old Bay Colony.

In sharp contrast to Mr. Hutchinson were two men who became famous leaders in the Revolution-Samuel and John Adams. In I765 Samuel Adams was a middle-aged man who had lost a fair patrimony, and who was barely able to support his family. John Adams was a young lawyer, just coming into promi- 


\section{AN EXPERIMENT IN DEMOCRACY}

nence; but he felt very keenly, as his interesting Diary enables us to see, that he had not a fair and equal opportunity in life because social opportunity and political power had come to be so largely monopolized by the small group of wealthy and closely interrelated families of which that of Thomas Hutchinson was the chief. And throughout the struggle with Great Britain, in which John Adams took a leading part, it is clear that in his mind the people of Massachusetts were endeavoring to emancipate themselves, not only from the autocratic control of the English government, but also from the domination of a Boston aristocracy; his animosity toward Thomas Hutchinson was much greater than toward King George or Lord North.

The way in which these two issues were often united is well illustrated in connection with the famous Stamp Act controversy. The Stamp Act required, among other things, that practically all legal documents should be executed on stamped paper. Almost every one in the colony, including Mr. Hutchinson, was opposed to the Stamp Act; but the Stamp Act could be resisted in one of two waysone legal and the other illegal. The legal way to resist it was not to execute any document which required the use of the stamped papers; the illegal way was to go on executing docu- 


\section{THE UNITED STATES}

ments just as if no Stamp Act existed. Thomas Hutchinson, and most men of wealth and position in the colony, preferred to resist the Stamp Act in the legal way, and they therefore adjourned the courts of law from time to time. This method appealed to conservative men, whose incomes were assured, who were not much affected by a temporary cessation of business, and who wished not to compromise their position by any action that could be called illegal. But rising young lawyers like John Adams found that if the courts closed their fees were cut off and their position at once became precarious. The closing of the courts, John Adams wrote in his Diary, "will make a great chasm in my affairs, if it does not reduce me to distress." And in another place he says that he was just at the point of winning a competence and a reputation "when this execrable Stamp Act came for my ruin and that of my country."

This naïve statement reveals one of the reasons-not the only reason, but one of the reasons - why John Adams, and all those who depended on fees and wages for a living, those whose interest it was to have business in a flourishing condition, were in favor of the more radical method, the illegal method, of resisting the Stamp Act, while men of wealth who lived on their incomes could afford to 


\section{AN EXPERIMENT IN DEMOCRACY}

adopt the more cautious and conservative method. And thus it happened that John Adams came to think Thomas Hutchinson as much an enemy of colonial rights as $\mathrm{Mr}$. Grenville. He convinced himself that $\mathrm{Mr}$. Hutchinson and his wealthy friends, while professing to oppose the Stamp Act, were really tools of the British government and were trying in this indirect way to force the people to submit to the Stamp Act. He reasoned that the Boston aristocracy was able to maintain its privileged position in Massachusetts only because it was backed by the British government; and thus the struggle against parliamentary taxation came to be identified with the struggle against a privileged class in the colony.

It is this aspect of the Revolution that gives , it its chief significance for modern democracy. The privileged classes in the Colonies, generally speaking, never really desired separation from Great Britain. They took old England as their ideal. Outside of New England most educated men were educated in England, and wished for nothing better than to fashion their clothes, their houses, their minds, and their manners on the best English models. They opposed parliamentary taxation because they wanted to manage their own affairs in miniature parliaments, where they 


\section{THE UNITED STATES}

could carry on miniature contests with the governors for the control of the purse, after the manner of the English Parliament in the seventeenth century. In no sense were they democrats; and they were as much afraid of radical movements in the Colonies as they were of British oppression. They wanted to preserve their liberties against Parliament, without sharing their privileges with the people in the Colonies. They wanted home rule, but they wanted to rule at home. Left to themselves, the governing classes in America would never have carried the contest to the point of rebellion, would never have created an independent state.

The opposition to this ideal gradually transformed the Revolution into a social as well as a political movement. Men of true democratic feeling came to see that the mere maintenance of what were called English liberties would leave things much as they were, even if the Colonies should separate from Great Britain. They wanted not simply an independent state, but a new kind of state. They were aiming at something more than could be justified by an appeal to the customary rights of Englishmen. Whether the customary rights of Englishmen supported the contention of the Colonies or the contentions of the king depended upon fine points 46 


\section{AN EXPERIMENT IN DEMOCRACY}

in law and history. But it was a question that could be ably argued on both sides. In any case, there was nothing in the customary rights of Englishmen that could be used in support of equal rights for all, poor and rich alike. And so, step by step, the radical leaders broadened out their political theory, and came finally to rest their cause not merely on the positive and prescriptive rights of Englishmen, but upon the natural and universal rights of man as well.

As the Revolution ceased to be a mere contest for the rights of Englishmen and took on the character of a contest for the rights of man, it acquired an idealistic and semimystical quality and gathered to itself, as all such movements do, the emotional force of a religious conviction. Mr. Lecky says that the American Revolution was essentially sordid, being concerned fundamentally with a mere money dispute. There was much that was sordid in the motives and the actions of many men who took part in the Revolutionary War, but nothing could be more profoundly wrong than to regard the principal leaders as inspired by no higher motive than that of safeguarding their property. The conflict with ' Great Britain began as a money dispute; but in the end it came to be transfigured, in the minds of the American patriots, into one of the 


\section{THE UNITED STATES}

great epic conflicts of the world. We have ourselves lived through such a transfiguration. The Great War began as a conflict for land and trade, but it speedily took on, in the minds of the people concerned, the aspect of a titanic struggle between the powers of light and of darkness, a struggle which men fondly, if vainly, hoped would bring in a new international order based upon the principles of justice and humanity. So it was with the American Revolution. American patriots came to think of themselves as hazarding their lives and their fortunes for the sake of a new social order, the ideal society founded upon the enduring principles of liberty, equality, and fraternity.

There is a striking similarity between the ideals and the language of the American patriots and the radical leaders of the French Revolution. They speak with the same lyrical enthusiasm, like men who are defending and propagating a new religion. "It is impossible," writes Richard Henry Lee, "that vice can so triumph over virtue as that the slaves of Tyranny should succeed against the brave and generous asserters of Liberty and the just rights of humanity." Consider the dry common sense with which Doctor Johnson disposed of the alleged tyranny of Great Britain: "But I say, if the rascals are so prosperous, op48 


\section{AN EXPERIMENT IN DEMOCRACY}

pression has agreed with them, or there has been no oppression"; and contrast this with the reverent solemnity with which John Adams speaks of his associates as belonging to "that mighty line of heroes and confessors and martyrs who since the beginning of history have done battle for the dignity of and happiness of human nature against the leagued assailants of both."

John Adams was one of the most hardheaded of the radical leaders, no unbalanced visionary dreaming fantastic dreams, and yet John Adams, in I775, clearly thought of himself as engaged in a great epoch-making event, far transcending any mere rupture of the British Empire or the establishment of an independent state. This is how he thinks of the meaning of the Revolution:

The form of government which you admire when its principles are pure is admirable; indeed, it is productive of everything which is great and excellent among men. But its principles are as easily destroyed as human nature is corrupted. Such a government is only to be supported by pure religion or austere morals. Public virtue cannot exist in a nation without private, and public virtue is the only foundation of republics. There must be a positive passion for the public good, the public interest, honor, power, and glory established in the minds of the people, or there can be no republican government, or any real liberty, and this public passion must be superior to all private passions. ... 


\section{THE UNITED STATES}

... Is there in the world a nation which deserves this character? There have been several, but they are no more. Our dear Americans perhaps have as much of it as any nation now existing, and New England perhaps has more than the rest of America. But I have seen all along my life such selfishness and littleness even in New England that I sometimes tremble to think that, although we are engaged in the best cause that ever employed the human heart, yet the prospect of success is doubtful not for want of power or of wisdom, but of virtue.

In no unreal sense John Adams and his associates thought of themselves as undertaking something new in the history of the world; they were undertaking the novel experiment of founding that ideal community, a republic founded upon virtue and devoted to the regeneration of the human race.

\section{III}

It is thus clear that the American Revolution was a twofold movement: it was a movement for the separation from Great Britain; it was also a movement for the abolition of class privilege, for the democratization of American politics and society, in some measure for the inauguration of an ideal state. The Declaration of Independence reflects and expresses this twofold character of the Revolution. On the one hand it is a declaration of 


\section{AN EXPERIMENT IN DEMOCRACY}

the reasons which justified the separation from Great Britain; on the other hand it is a charter of democracy, a charter which expresses in classic form the universal rights of mankind.

The Declaration of Independence is a short document, which may be printed in four small pages; and the larger part of it is devoted to the specific grievances against the King of Great Britain. The Parliament is not mentioned because the revolutionists had accepted, at that time, the federal theory of the Empire - the theory that the Colonies had never been subject to the Parliament, but only to the king. And so the Declaration, affirming that "the history of the present King of Great Britain is a history of repeated injuries and usurpations, all having in direct object the establishment of an absolute Tyranny over these States," proceeds to enumerate a long list of such injuries and usurpations, all of which have to do with specific acts: laying taxes on the Colonies or designed to limit or destroy the legislative independence of the colonial governments. This part of the Declaration is now rarely read and never remembered; and rightly so, for these specific acts charged against George III, and once so vital, are now dead issues.

But there is another part of the Declara- 


\section{THE UNITED STA'TES}

tion - a short ten lines of print - which every one thinks of when the Declaration is mentioned, and which is the only part of that famous document which most people have ever kept in mind. This part of the Declaration, the most significant and the most famous part, is as follows:

We hold these truths to be self-evident, that all men are created equal, and that they are endowed by their Creator with certain unalienable Rights, that among these are Life, Liberty, and the pursuit of Happiness. That to secure these rights Governments are instituted among men, deriving their just powers from the consent of the governed, that whenever any Form of Government becomes destructive of these ends, it is the Right of the People to alter or abolish it, and to institute new Government, laying its foundations on such principles and organizing its powers in such form, as to them shall seem most likely to effect their Safety and Happiness.

On first thought it may appear strange that the part of the Declaration of Independence which is most famous and best remembered is precisely the part which is least directly concerned with the grievances which led the Colonies to declare independence. But the reason for this is simple. It is that the specific grievances of the Colonies concern the world but little, while the principles upon which just government rests are of universal in- 


\section{AN EXPERIMENT IN DEMOCRACY}

terest. The few phrases which make the Declaration famous deal not with the rights of Americans or Englishmen only, but with the rights of man; and in so far as the principles which they proclaim are valid, they are valid for Frenchmen, or Russians, or Chinese no less than for Americans and Englishmen. This is why these phrases still live, and this is why the American Revolution has a universal and permanent as well as a local and temporary importance. This universal significance is that for the first time in the modern world a new and potentially powerful nation was "dedicated to the proposition that all men are created equal," and founded upon the principle that the legitimacy of any government rests upon the will of the people instead of the will of God or of the State. And for a hundred years the example of the United States has been one of the strongest supports of this new faith which, however often forgotten or betrayed, is now accepted by the better part of the world.

When the Revolutionary War began few people in Europe supposed that the Colonies could win their independence. If they had been entirely united their chances would have been better. But the fact is that at least one-third of the people (this is the estimate of John Adams) were indifferent or actively 


\section{THE UNITED STATES}

opposed to the American cause. These were the Loyalists-Americans who remained loyal to Great Britain. They were not only numerous, but they included many of the ablest and most influential men in the Colonies, being largely recruited from the upper classes - landowners, merchants, clergymen, and officials, who had hitherto constituted the governing class, and who opposed the Revolution quite as much because of their fear of democracy as on account of any strong attachment to Great Britain. This division within their own ranks greatly weakened the colonists and gave to the struggle something of the character of a civil war.

But besides this class division, which appeared in every colony, the chances of success were immensely lessened by the persistence and even the accentuation of the old rivalries between the different colonies. "There ought to be no New England man, no New-Yorker, known on the continent, but all of us Americans." So Christopher Gadsden wrote at the time of the Stamp Act Congress in $\mathbf{1 7 6 5}$. It was a noble ideal of which most men no doubt vaguely felt the force; but neither New England men nor New-Yorkers nor South-Carolinians could be wholly transformed overnight. It took a hundred years to effect this transformation; and the student 


\section{AN EXPERIMENT IN DEMOCRACY}

of the Revolution is sometimes amused, but more often amazed and disheartened, by the petty jealousies, the personal animosities, the hopeless provincialism, and the sordid corruption which everywhere prevailed and which but gave an added luster to the fame of those outstanding Americans, such as Washington and John Adams and Franklin, without whose services the Revolution must have completely failed.

Of these three illustrious leaders the name of Washington stands out as a symbol of all that is heroic and admirable in the annals of his country. He was a Virginia planter, accounted the wealthiest man in the Colonies, whose life had been chiefly given to managing, with the most scrupulous care and with the highest efficiency, the estate which lay on the south bank of the Potomac at Mount Vernon. Scarcely a politician, he was yet a man of broad vision, who foresaw a great future for his country and was actively interested in the development of the great west that lay beyond the Alleghanies. Such military experience as he possessed had been gained in the French and Indian War; and particularly in the famous Braddock Expedition he had revealed a knowledge of frontier Indian fighting which the British general did not possess and declined to take advantage of, 


\section{THE UNITED STATES}

and in this disastrous retreat he had exhibited a courage and a resourcefulness which had won him the respect of the British and the confidence of his countrymen.

It was on June 17, 1775, that this Virginia colonel was appointed to be "General and Commander-in-Chief of the armies of the United Colonies." It was a high-sounding title for the leader of the nondescript collection of soldiers who fought the Revolutionary War; but no man who ever undertook a great task was better fitted for its manifold duties. For the exhibition of brilliant military genius there were during the eight years of war but few opportunities; but for patience and resolution, for sound, practical judgment, resourcefulness, for ability to make the most of an untoward situation or a hopeless defeat, for the spirit that could inspire soldiers and civilians with loyalty to a cause which always seemed irretrievably lost - for all these qualities the American War of Independence furnished a test which only a great soul could have met with success.

It was the merit of Washington that he possessed these qualities, each in perfection, and all in the happiest combination. He was the man of staid mind and impregnable character who gathered all the scattered and discordant forces of the Revolution and directed 56 


\section{AN EXPERIMENT IN DEMOCRACY}

them to the achievement of the great end, so modest that he thought himself incompetent to the task, yet of such heroic resolution that neither difficulties nor reverses nor betrayals could bring him to despair; a man of rectitude, whose will was steeled to finer temper by every defeat, and who was not to be turned, by any failure or success, by calumny, by gold, or by the dream of empire, from the straight path of his purpose. At the end of eight years of unremitting labor, which depleted his fortune and for which he asked no more than the payment of his personal expenses, that purpose was at last achieved.

No man was ever more rightly called the father of his country; but even the indomitable resolution of Washington, supported by the dogged persistence and garrulous common sense of John Adams and the suppleness and resource of Franklin's intelligence-even these would not have sufficed to win independence. It was America's good fortune that in this decisive hour of her history France came to stand by her side. Without the aid of France, the men who signed the Declaration of Independence would have pledged their lives, their fortunes, and their sacred honor in vain, and would have been known to history as rebels against rightful authority instead of defenders of human liberty. 


\section{THE UNITED STATES}

The influences that brought France to stand with America bear a curiously apt relation to these two characteristic phases of the Revolution that have been mentioned. No one could have had less sympathy with rebellious subjects proclaiming the doctrine of popular sovereignty than Louis XVI, the chief exemplar of autocracy in Europe; but no one could regard with greater satisfaction the disruption of the British Empire. For a hundred years England and France had struggled in peace and in war, on land and on the sea, for the possession of the New World as the basis of maritime and commercial supremacy. And England had won. In every stage England had won; and never so completely as in the last war. The Peace of Paris of 1763 , by which France had been expelled from America and India, was the profoundest humiliation which France had suffered, and the memory of it still rankled.

Inevitably, therefore, as a matter of practical politics, the French government sought to redress the balance of power in Europe and the world by diminishing the power of Great Britain. The persistent promoter of this policy was the Foreign Minister, Vergennes, who watched with delight the growing dispute between the mother country and the American provinces, and who labored 


\section{AN EXPERIMENT IN DEMOCRACY}

from the outbreak of hostilities to bring France into alliance with the revolting Colonies. Early in the war, through a fictitious business firm organized by the playwright, Beaumarchais, the government furnished two hundred thousand dollars' worth of supplies and military stores; after the Declaration of Independence Vergennes arranged with Franklin for a regular subsidy of two hundred thousand dollars a year; and finally, after the great victory of the colonial troops at Saratoga, an open military and commercial treaty was signed between the United States of America, recently founded upon the revolutionary principle of popular sovereignty, and his Most Christian Majesty, Louis XVI, by Grace of God King of France and Navarre.

So far as the French government was concerned the alliance between the two countries was inspired by the desire to disrupt the British Empire and thereby increase the power of France. But the Franco-American alliance was something more than a diplomatic entente. The alliance was welcomed in France with immense popular enthusiasm; and this enthusiasm was inspired, not by hatred of England (never were the English more admired in France than at this time), but by a profound sympathy with the ideals of liberty and human welfare upon which the Revolu- 


\section{THE UNITED STATES}

tion was based and which found classic expression in the famous Declaration of Independence. Within half a century a new spirit had arisen in France. A generation of brilliant writers, of whom Voltaire, Montesquieu, and Rousseau were the leaders, had transformed the thinking and the aspirations of the French people. By trenchant criticism and corrosive satire and passionate denunciation of corruption, hypocrisy, and injustice, they destroyed the moral foundations of the monarchy and the Church and prepared the way for that great Revolution which was destined to transform the old European world.

Thus it happened that in 1776 the French, like the Americans, were dreaming of a new era. They had caught the vision of a regenerated society - a society in which enlightenment would banish ignorance and vice, in which selfishness and brutality would give way to a kindly fraternity, in which the generous and humane instincts of the natural man would find expression in law and customs designed to establish and perpetuate the general welfare. And so it was that in this soft springtime of the modern world forward-looking men observed with profound interest the birth of a new nation on the western continent. Repelled by the corrupt and artificial life of 


\section{AN EXPERIMENT IN DEMOCRACY}

Europe, everywhere encumbered with the debris of worn-out institutions, they turned to America as a kind of concrete example of their imagined state of nature. Their very ignorance of America enabled them to confer upon it more virtues than it in fact possessed. In contrast with Europe, so oppressed with defenseless tyrannies and useless inequalities, how superior seemed this new land of promise where every citizen was a free man, where the necessities of life were the sure reward of industry, where manners were simple, where vice and crime had almost disappeared, and where native incapacity was the only effective barrier to ambition!

When Benjamin Franklin arrived in France in $\mathbf{I} 776$ he was therefore something more than the official representive of the Congress of the United States. To the French mind he was the incarnation of the qualities which a state founded on reason and nature would tend to develop in all men. This man who had begun life as a printer's boy and was now the chosen representative of his country on a difficult mission, this self-educated philosopher whose discoveries were known to every savant in Europe, this Friend of the Human Race who had "wrested lightning from Heaven and the scepter from the Tyrant's hand"-this man was, after all, no more than one of nature's 


\section{THE UNITED STATES}

noblemen, such as free institutions might be expected to produce.

And in some ways Franklin was better than his reputation. The suppleness of his plastic mind enabled him to take on without effort the external qualities of the French temperament, while retaining the homely wit and wisdom and the serene and imperturbable geniality which was his native character. The result was that never before nor since has any man in a foreign country received such continued applause or been the object of such universal affection as fell to Franklin in France. John Adams, who liked the French none too well and who might have felt the jealousy of a less successful rival, said of Franklin:

His reputation was more universal than that of Leibnitz or Newton, Frederick or Voltaire; and his character more beloved and esteemed than any or all of them. . . His name was familiar to government and people, to kings, courtiers, nobility, clergy, and philosophers, as well as plebeians, to such a degree that there was scarcely a peasant or a citizen, a valet de chambre, a coachman or footman, a lady's chambermaid or a scullion in a kitchen, who was not familiar with it, and who did not consider him as a friend of humankind. When they spoke of him, they seemed to think he was to restore the Golden Age.

The Golden Age! This phrase gives us indeed the secret of Franklin's popularity. 


\section{AN EXPERIMENT IN DEMOCRACY}

He was in French eyes the beau-ideal of the natural philosopher, the incarnation of all those amiable and excellent qualities which were potential in the nature of men, and which would be developed in all men when institutions were made to conform to reason and justice. The enthusiasm of the French people for America and for Franklin was but the measure of their passionate desire for the regeneration of France, a symbol of the community of hopes and ideals which bound the two countries together. 


\section{IV}

DEMOCRACY AND GOVERNMENT

I

\HEN the United States of America assumed her place among the independent nations of the earth, the regeneration of the human race was far from an accomplished fact. Europeans were prepared to regard the event as a forecast of a new era in human history; but it would have been an optimist indeed who could have seen in even the most favored of the thirteen little states that composed the new nation that ideal republic, founded upon virtue and assuring the reign of felicity, which John Adams in his generous moments had professed to believe in. On the contrary, the country was exhausted and demoralized. The poverty and destitution which everywhere prevailed among the mass of the people was only thrown into stronger relief by the prosperity of those who had somehow managed to preserve their estates, or of those newly rich whose swollen fortunes were the 64 


\section{AN EXPERIMENT IN DEMOCRACY}

reward of shameless profiteering. The sense of public probity had been immensely weakened by the unrestrained lawlessness of many years as well as by the unlimited issue of government obligations that were scarcely worth the paper they were printed on. Respect for law had been half destroyed by the feebleness of governments which, under the stress of civil war, had fallen to the level of imbecility. For many years after the treaty of I 783 there was no question of an ideal state or of the regeneration of the human race; the question was of any tolerable state, of any stable government. The ideal republic might come, it might conceivably come in America; but the immediate task which confronted the United States was to demonstrate to the world's satisfaction that any republic could endure for a generation.

\section{II}

Probably no people indeed has ever been more constantly preoccupied with the question of the proper form of government than the people of the United States. The question of government was one of the questions that drove men out of Europe into America in the seventeenth century. The colonial assemblies were perpetually quarreling with the governor over their respective powers. The Revolution 


\section{THE UNITED STATES}

turned upon a question of government; and throughout the Revolutionary War and for some years after, one chief occupation of the people was the manufacture of constitutions. Having finally adopted a federal constitution in 1787 , the people and their leaders began to discuss the question of how it ought to be interpreted. They adopted the constitution first and then tried to find out what it meant, but never could agree, and at last had to fight a desperate civil war to determine the matter.

Nevertheless, these constant wrangles about the form of the government, at least since the Revolution, have not, for the most part, had to do with fundamental questions. The French people have in the nineteenth century discussed the question of government as much as the Americans; but in France the dispute has involved fundamental issues, such as the question of whether a divine-right monarchy or a democratic republic is better. Such a dispute never has nor ever could exist in America; and this is a fact of fundamental importance for an understanding of American history and institutions-namely, that in all of our history no sane person has ever seriously proposed that a divine-right monarchy or any other kind of monarchy should be established. The only king which Americans were ever willing to recognize, even in colonial days, was 


\section{AN EXPERIMENT IN DEMOCRACY}

a king who was too far away to have any power over them. The most deep-rooted . political instinct which Americans have, an instinct which determines all their thinking, is the feeling that they can and will, as a matter of course, govern themselves. This idea is so fixed and so universally held that if any one should suggest any kind of government other than self-government as proper for Americans the proposal would be taken as a species of joke. The traditions of monarchy and Church and nobility, which are such powerful influences in Europe because they are so interwoven in all European history-these traditions simply do not exist in the United States.

Not only have Americans always been violently opposed to monarchical government, they have always been opposed to a highly centralized government, exercising its authority from a great distance and through officials unknown in the community where they act. In America the burden of proof commonly rests on the government. The American, therefore, likes to have a government that is limited as much as possible, that is nicely checked and balanced; and for this reason he likes to have a government that is close at hand, where it can be carefully watched and kept in its proper place. From the beginning of American history the people 


\section{THE UNITED STATES}

have accordingly held on like grim death to as much local government as possible, and have surrendered only gradually and under pressure any powers to the central government, whether state or national.

Such an attitude toward government is likely to be developed in any new country where people have to depend upon themselves and where individual initiative is at a premium; but the trait was already ingrained in the first settlers. America was settled, in large part, by people who left Europe in order to free themselves from the oppression of monarchy and Church. Separatists, Puritans, Nonconformists, Quakers, Scotch-Irish Presbyterians, Mennonites, Dunkers-these names are associated with those Europeans who were so eccentric in their views that they could not live comfortably at home. They were opposed to monarchy, opposed to hereditary nobility, opposed to bishops, opposed to May-poles, opposed to lawn sleeves, opposed to almost all the prevailing ideas and customs. Being temperamentally cantankerous, people with whom it went against the grain to submit to outward constraint, they were disposed to look within for some "inner light" or "scruple of conscience" which might serve as a guide to action. And so, in order to be free from the outward constraint of king or priest 


\section{AN EXPERIMENT IN DEMOCRACY}

or social custom, they came to America where there was room for all and no one to care what they thought or how they worshiped or whether they had much or little government.

Inevitably such eccentric people founded small and dispersed communities. The Pilgrims, asserting that it belongeth not to the magistrate "to compel religion, to plant churches by power, and to force submission to Ecclesiastical Government by laws and penalties," first went to Holland; but when they $\backslash$ could not be sufficiently "separated" there, they lifted up "their eyes to the heavens, their dearest country, and quieted their spirits." They also quieted their spirits by coming to the bleak New England coast and settling at Plymouth, a tiny little community that maintained its separate government for eighty years. They prefêrred not to unite with the Puritans who settled Massachusetts Bay, although the difference between the Puritans and the Separatists seems to the modern mind very slight. The Puritans themselves were no sooner established at Boston than they began to quarrel over the precise nature of that "due form of government both civil and ecclesiastical" which they came to America to establish; and some of them, being expelled,went off with Roger Williams to found another tiny commonwealth at Providence 


\section{THE UNITED STATES}

(Rhode Island), while others followed Thomas Hooker into a new wilderness and founded the colony of Connecticut. Still another group of Puritans, coming from London to. Boston, but not finding the due form of government precisely right in every detail, went on to New Haven and founded there a Bible commonwealth that suited them. In origin and in their ideas of religion and government, all of these people were very much alike. Had they chosen to live together under one state, that state, seventy years after the first settlement, would have had a population of less than eighty thousand. But in spite of the extreme hardships of the wilderness, in spite of the danger from the Indians, these eighty thousand eccentrics could not possibly subordinate themselves to a single government. They preferred to live separated, according to the "strong bent of their spirits," in five distinct and independent states, each one an ideal commonwealth.

During a century and a half of colonial history the jealousy of local liberties and the practice of local government became firmly established, and each colony as a matter of course managed its own affairs in complete independence of every other colony. The only bond of union between the colonies was the British government, and the people of 


\section{AN EXPERIMENT IN DEMOCRACY}

the various colonies had usually but little intercourse with one another. When John Adams went to Philadelphia in $\mathbf{1} 774$ to attend the first Continental Congress, he had never before been outside of New England. $\mathrm{He}$ entered New York with the same interested curiosity with which an American now goes for the first time to London; and he noted in his Diary, as the European tourist might do, his impressions of the people, of their dress and manners, of how their political institutions differed from those of New England, and commented upon the several kinds of food which he had for breakfast at the country seat of Mr. John Morin Scott.

This provincial point of view was not radically changed by the Revolution; and when independence was declared each colony regarded itself as an independent and sovereign state. It is true that independence was declared by the Continental Congress, but it was an associated declaration of the thirteen states. No colony. was bound by the act of Congress until it gave its adherence to that act; and, in fact, the colony of New York did not vote for independence until July 9th, seven days after the resolution was voted in Congress.

The resolution by which Congress voted in favor of independence included a recom6 


\section{THE UNITED STATES}

mendation to the effect that each state should proceed forthwith to form a new state government; and in fact each state, assuming full sovereign rights, established a government to suit itself. The Revolution thus created thirteen independent states, each with its own constitution and its own government; and this system of state governments became and has remained to this day the foundation of the United States and of its political system. The original state governments were modeled upon the old colonial governments (the colonies of Connecticut and Rhode Island indeed retained for many years their old colonial charters as constitutions), and the structure of these governments, in its essential features, was much the same in all the states. There were the county or town officials for purely local affairs; there were the elected assemblies, in most cases of two houses, for the making of state laws; and there were the governors, elected directly by the people (except in New York), to whom were intrusted the administrative and executive functions. There are now forty-eight states in the Union. Each one has a written constitution, in accordance with which its government is organized; and although in the course of time the trend toward a greater degree of democracy has brought about many modifications in detail, 


\section{AN EXPERIMENT IN DEMOCRACY}

the structural features of municipal, county, and state governments remain what they were at the close of the eighteenth century.

It was upon this foundation that the United States government was erected. While the sovereignty of the states was the accepted idea at the close of the Revolution, every one felt that the people of the Colonies were in some measure a common people with a common destiny, and that, as they had united for defending their rights and the winning of independence, so they must continue to act together in their dealings with the outside world. In other words, it was agreed that the thirteen independent states ought to unite in a federation. This union had been achieved during the war by means of the Continental Congress; but the Continental Congress was only a temporary body with no specifically determined powers - an assembly of deputies acting only upon instruction from their own governments, its authority limited to recommendations, and its influence such as the prestige of its members or the exigencies of war might give to it. To take the place of the Continental Congress, the states finally adopted, after much wrangling, the Articles of Confederation.

The Articles of Confederation created a federal government without any effective 


\section{THE UNITED STATES}

power. The states were as jealous of their sovereign rights then as states are now; and the creation of a strong federal government was contemplated with the same hesitancy with which the states of Europe now contemplate the creation of a strong League of $\mathrm{Na}$ tions. It was somehow imagined that an effective United States could be formed without depriving the individual states of any sovereign rights. The Articles of Confederation made no provision for a federal executive, and upon the federal Congress which was created they conferred nothing more than the right of recommending laws which the separate states were expected to enforce, but which in fact they enforced or not, as they saw fit. Such a federal union proved a complete failure. A government which could negotiate treaties, but could not execute them; which could levy taxes, but could not collect them, merited and received the contempt of every one both at home and abroad. Within a few years it was found that in order to avert the dissolution of the confederation, as well as to protect the common interests of the states against foreign aggression, a more perfect union would have to be formed. This more perfect union was achieved by the adoption of the Constitution of 1787 , which went into effect in 1789 and has remained in force until the present time. 


\section{AN EXPERIMENT IN DEMOCRACY}

III

The Constitution of 1787 was declared by Mr. Gladstone to be the "grandest work ever struck off by the hand of man at a given time." The men who made it would not have claimed so much for their handiwork. The Constitution was a compromise between many divergent interests, and the result was that almost no one was very well satisfied with it. Some thought it created a government which was too weak to be effective, and some thought it created a government so strong as to be dangerous. James Madison defended the Constitution by saying that under all the circumstances " $i t$ was the best we could do." At the time, this was thought to reveal an optimistic attitude of mind; but most people could at least take refuge in the thought that things might turn out better than was expected.

If it could have been foreseen how much power the federal government would be able to assume, the Constitution would have been rejected by a great majority of the people; for the states were still unwilling to surrender the principle of sovereignty. In the new Constitution, therefore, no more power was conferred upon the federal government than was thought to be absolutely necessary; and 


\section{THE UNITED STATES}

hence the fundamental legal principle which governs the distribution of the power between the federal and the state governments, respectively, is this: The states have all powers not expressly conferred by the Constitution upon the federal government, or not expressly denied by the Constitution to the states. That there might be no doubt about the matter, this principle was formulated and adopted as the Tenth Amendment to the Constitution in the following terms: "The powers not delegated to the United States by the Constitution, nor prohibited by it to the States, are reserved to the States respectively, or to the people!" If this principle is once thoroughly understood the distribution of powers in the American political system, which sometimes seem so complex to foreigners, will present no great difficulty. There are the state governments, each having jurisdiction within its own territory, and there is the federal government at Washington having jurisdiction over the whole territory of the United States. The federal government exercises such powers only as are expressly conferred upon it by the Constitution; the state governments exercise all powers not expressly denied to them or expressly conferred upon the federal government.

The federal government, upon which the Constitution conferred certain powers, is in 76 


\section{AN EXPERIMENT IN DEMOCRACY}

its structure similar to the state governments. It is a government of three branches-executive, legislative, and judicial-intended to be so nicely checked and balanced, in respect to the powers conferred upon each branch, that no one branch could usurp the powers conferred upon either of the others. The executive branch is intrusted to the President, originally elected by an electoral college, but now in fact elected directly by the people, for a term of four years. Aside from a limited right of vetoing laws passed by Congress, the chief function of the President is to "take care that the laws be faithfully executed." In order that he may do this, he is made the commander-in-chief of the army and navy, and is given the power to appoint ambassadors, judges of the Supreme Court, and all federal officers whose appointment is not otherwise provided for. In addition, the President negotiates all treaties with foreign powers; but both the treaties negotiated and the appointments made by the President become valid only when approved by a two-thirds vote of the Senate.

The legislative branch of the federal government consists of the Congress, composed of an upper house called the Senate, and a lower house called the House of Representatives. The Senate is composed of two members from 


\section{THE UNITED STATES}

each state, whether large or small, chosen originally by the state legislatures, but now in all states by the people, for a term of six years. The Senate was a concession to the small states, which wished to preserve their equality with the large states, so that even to-day a state like Rhode Island, with a population of about six hundred and fifty thousand, has equal weight in the Senate with a state like New York, with a population of over ten millions. But the Senate was also a concession to those who feared the unchecked power of the people. Chosen by the state legislatures, for a long term of service, and made up presumably of older men, the Senate was designed to prevent over-hasty action by the House of Representatives.

The House of Representatives is composed of men chosen directly by the people for a term of two years. The number from each state is determined according to the population of the state, and in each state every one has a right to vote for members of the House of Representatives who has a right to vote for the members of the lower house of the legislature of that state. The House of Representatives was thus a concession to the large states; but it was also a concession to the principle of democracy. It was and is as democratic a body as the states respectively 


\section{AN EXPERIMENT IN DEMOCRACY}

wish to make it. In Kansas, for example, where women are allowed to vote for members of the state legislature, women may vote for members of the House of Representatives; but in Pennsylvania, where women are not allowed to vote in state elections, they may not vote for United States Congressmen, either.

The third branch of the federal government is the judicial branch, "which is vested in one Supreme Court and in such inferior courts as Congress may from time to time ordain and establish." The Congress has in fact established a number of such inferior courts, the most important of which are the circuit and the district courts. There is at least one district court of the United States in each state, and in the more populous states there are sometimes three, or even four, and the districts are themselves grouped in nine judicial circuits in which the judges of the Supreme Court from time to time hold courts for the hearing of appeals from the district courts. These federal courts, which are of course quite distinct in jurisdiction and in personnel from the state courts, thus constitute a kind of judicial hierarchy, with the district courts at the bottom, above them the circuit courts, and above the circuit courts the Supreme Court. The jurisdiction 


\section{THE UNITED STATES}

of the federal courts extends to "all cases ... arising under the Constitution, the laws of the United States, and treaties made, or which shall be made, under their authority."

Such is the form of the federal government upon which the Constitution expressly confers certain powers. Aside from the power of the President to negotiate treaties, the powers which the Constitution confers upon the federal government are essentially all contained in Section VIII, which defines the legislative authority of the federal Congress. This section is of sufficient importance to quote at length:

The Congress shall have power to lay and collect taxes, duties, imposts, and excises, to pay the debts and provide for the common defense and general welfare of the United States; but all duties, imposts, and excises shall be uniform throughout the United States.

To borrow money on the credit of the United States.

To regulate commerce with foreign nations, among the several States, and with the Indian Tribes.

To establish an uniform rule of naturalization, and uniform laws on the subject of bankruptcy throughout the States.

To coin money, regulate the value thereof, and of foreign coin, and fix the standard of weights and measures

To provide for the punishment of counterfeiting the securities and current coin of the United States.

To establish post offices and post roads.

To promote the progress of science and the useful 80 


\section{AN EXPERIMENT IN DEMOCRACY}

arts, by securing for limited times to authors and inventors the exclusive right to their respective writings and discoveries.

To constitute tribunals inferior to the Supreme Court.

To define and punish piracies and felonies committed on the high seas, and offenses against the law of nations.

To declare war, grant letters of Marque and Reprisal, to make rules concerning captures on land and water.

To raise and support armies, but no appropriation of money to that use shall be for a longer term than two years.

To provide and maintain a navy.

To make rules and regulations for the government and regulation of the land and naval forces.

To provide for calling forth the militia to execute the laws of the Union, suppress insurrection and repel invasion, .... and

To make all laws which shall be necessary and proper for carrying into execution the foregoing powers, and all the other powers vested by this Constitution in the Government of the United States, or any department or officer thereof.

Such are the powers expressly conferred upon the United States government by the Constitution. The powers expressly denied to the states are to make treaties with one another or with foreign states, to coin money or issue bills of credit, pass bills of attainder, ex post facto laws, or laws impairing the obligation of a contract, to levy import or export duties, to keep ships of war in time of peace, or to grant titles of nobility. 


\section{THE UNITED STATES}

It was of course very easy to say that the Congress of the United States should pass only such and such laws. But suppose the Congress should not observe the limits set in the Constitution? Who would restrain it? It was easy to say that the states should not pass such and such laws-for example, a law impairing the obligation of a contract. But suppose some state should pass a law impairing the obligation of a contract? Who would restrain it? Where virtually sovereign powers are divided between two distinct governments, conflict is sure to arise. The distribution of powers between the states and the federal government is an essential feature of the American federal system, and conflicts have often arisen between the states and the federal government in respect to their proper sphere of activities. Some method of determining these questions without resorting to war was therefore necessary.

As a matter of fact, it fell to the Supreme Court to decide these disputed questions. If the Congress passes a law, or if any state legislature passes a law, in either case any one may refuse to obey the law; and if he is arrested in consequence and brought to trial, he may plead that the law in question is unconstitutional-that is, that the Congress or the state legislature is forbidden by the Constitution 


\section{AN EXPERIMENT IN DEMOCRACY}

of the United States to pass such a law. Such a plea, if it is allowed, brings the case before a federal court, and may ultimately bring it before the Supreme Court, because the jurisdiction of the federal court extends to "all cases arising under the Constitution of the United States"; and it then becomes the duty of the court, if the case cannot be decided on some other ground, to raise and to decide the question of the constitutionality of the law in question. Acting in this way, the Supreme Court has often declared laws of Congress null and void on the ground that the Congress has exceeded the powers given to it by the Constitution; and it has still more frequently declared state laws null and void on the ground that the state is exercising powers denied to it by the Constitution. Thus the Supreme Court is not only a strictly judicial body; it is also a kind of umpire or arbitrator which settles disputes in respect to the respective powers of the federal and state governments. In settling such disputes, it often has to declare what is or is not law, and so it becomes in fact a lawmaking body as well as a law-interpreting body.

Such in brief outline is the framework or structure of the American political system. It must be confessed that it is not simple. The principle for determining the distribution 


\section{THE UNITED STATES}

of power between the various governments may be clear enough, but the machinery itself is complicated, and there is a great deal of it. The number of elections to be held, of offices to be filled, of legislative bodies to be kept going, is something wonderful. Consider the lawmaking bodies alone! To say nothing of county and municipal governments throughout the Union, there is the Congress of the United States assembling every year, and forty-eight state legislatures assembling at least once in two years, to make more laws. A more extensive plant than we have in America for the manufacture of statutes does not exist on the earth. Every year thousands of new laws, state and national, are madevery soon forgotten, most of them, it is true, and most of them useless. But then most of them are harmless also, because most statutes become obsolete unless the people are interested in their enforcement, since no one in America imagines that laws can have any force if they are not an expression of the public will.

In America the enforcement of law as well as the making of law rests with the people; but the will of the people is not quite the same thing in both cases. Laws that are made are 84 


\section{AN EXPERIMENT IN DEMOCRACY}

the expression of the popular will in the sense that all statutes are formulated and passed, and all executive decrees are issued, by assemblies elected by the people, or by officials appointed by some one who is himself elected by the people. But who are the people? And do the legislative bodies and executive officials always represent the wishes of the people?

The people, so far as the making of laws is concerned, have never been in America, or in any other country, composed of all the citizens. The right of voting for legislative bodies and officials has always been limited to certain persons. Nor has this limited class of persons, this "electorate," ever been able to express its will perfectly, or to get it perfectly represented in government. No form of government works perfectly. Democratic government does not work perfectly; and democratic government in the United States is no exception to this rule. But the validity of the principle upon which the political system of the United States rests has in this country never been seriously questioned. When the American sees that his system of government works badly, he does not deny his faith and fall into despair. He says, cheerfully, "We must set this right; we must have more laws; we must amend the Constitution." The aver- 


\section{THE UNITED STATES}

age American never doubts that the remedy for democracy is more democracy.

The whole history of the United States has been a process of trying to get more democracy. In 1789 every state restricted the right of voting more or less narrowly. At that time it was generally thought that to place the control of government unreservedly in the hands of even a minority of the people was to have a great deal of democracy. It was thought that only those who had property to protect would have a sufficiently intelligent interest in government to be intrusted with political power; only those who had a "stake in the country" ought to have a share in saying what was to be done with the country. As John Jay was fond of saying, "Those who own the country ought to govern it."

But even at that time there were those who had more interest in men than they had in money, and more faith in the virtue of the people than they had in the virtue of wealth. Thomas Jefferson, the author of the Declaration of Independence, was one of those who never lost faith in the principles of that document; and he became the leader of the Democratic-Republican party, which forthwith raised the cry of "aristocracy" and "oligarchy" against the Federalist party, which was supported mainly by the wealthy and edu- 


\section{AN EXPERIMENT IN DEMOCRACY}

cated classes. But although Jefferson and his party came into power in 1801 , it was not until the period of 1820-30, when the more democratic frontier states of the Middle West began to exercise a determining influence upon the political history of the United States, that the old restrictions on the suffrage began to be abolished. This great democratic movement culminated in the election of Andrew Jackson (1828-37) as President. A frontier Indianfighter, "Old Hickory" was a man of the people with a profound faith in the worth, the integrity, and the sound sense of the average man. From this period universal manhood suffrage became the general practice in the United States, and political control passed in considerable measure from the cultured and educated classes to the mass of the pepple.

But universal manhood suffrage brought its evils and its problems. As the electorate became larger, the nomination of candidates for office was taken out of the hands of prominent officials and placed in the hands of mass-meetings, which in turn developed into "nominating conventions" made of delegates elected by the members of the party concerned. The nomination convention offered an excellent opportunity for the professional politician to construct a closely integrated "political machine," which manipulated the 7 


\section{THE UNITED STATES}

nomination of candidates and controlled the party through the spoils of office and through the relations it might establish with business or other "interests" seeking protection or advantage. It thus came about that the honest voter had usually only a choice between two candidates, which was often a choice between two evils. Each candidate was nominated in a more or less secret and corrupt way, so that whichever candidate was elected to office was likely to have "obligations" to those who had procured his nomination and his election. These "obligations" were not so much to the people as to individuals or groups of individuals who had axes of their own to grind.

This system of corrupt "machine politics" at last became so perfect in its kind that even the easy-going Americans could not tolerate it, and in recent years the nominating convention has been rapidly modified or abolished altogether. Many states now have what are called "primary elections"- that is, elections within each party, or without regard to party, for the purpose of nominating candidates to stand for the final election. By this system all voters, or at least all voters who are registered as members of a recognized party, may take part in nominating the candidates who are to be finally voted for. To some 


\section{AN EXPERIMENT IN DEMOCRACY}

extent this has diminished the influence of the professional politician by enabling the rank and file to choose men for office who will be more free to carry out their wishes.

But it is of course still possible that the elected representatives may not carry out the wishes of the people. Municipal councilors, state assemblymen, members of the House of Representatives, even United States Senators, are not demigods, but more or less ordinary human beings. They have their political careers to consider, often place loyalty to party above loyalty to ideas even if they have any, or to the welfare of the people even if by chance they know what it is. Consciously or not, they are often the instruments of malign influences-selfish or corrupt or vicious organizations that prey upon society and exploit the people. Thus it happens that the laws passed by the representatives of the people, even when these representatives are men whom the people choose willingly, are often not such as the people desire.

To correct this evil by bringing the action of elected representatives more directly under popular control even during their terms of office, there has been under way for many years a movement which is symbolized by the letters I. R. R.- the Initiative, the Referendum, and the Recall. The Initiative (which 


\section{THE UNITED STATES}

is at least as old as the French Revolution) is a scheme which permits a certain proportion of the voters to initiate legislation-that is, to formulate and propose bills which the legislature must consider and vote upon. The Referendum is a scheme which requires certain bills or laws passed by the legislature to be referred to the voters for approval or rejection. The Recall is a method of permitting the voters to "recall"- that is, to remove from office-an elected official before the term of his office expires, in case he acts contrary to their wishes. These methods, which have been adopted to a greater or less extent in a number of states, are all designed to give to the people a more direct and a more effective control of legislation, and of the conduct of elected representatives. Their effect is in some measure to transform elected officials from representatives to agents of the people.

Meantime, the trend toward a greater degree of democracy has taken the form of an extension of the suffrage. Many people have always regarded women as reasonably honest and intelligent - at least, as much so as men; and for a long time these people have been asking a very embarrassing question. If it is true, they say, that "all just government rests upon the consent of the governed," why should 90 


\section{AN EXPERIMENT IN DEMOCRACY}

women, who have as well as men to submit to government, not be allowed to consent to it also. No convincing reason for not allowing women to vote has ever beèn advanced which would not apply equally well to men. But it takes a great deal of reason to overcome the force of a little inertia; and it is only in recent years, when the economic and intellectual emancipation of women has somewhat broken down the solidarity of the family, that the political emancipation of women has made much headway. At the present time women have full or partial rights of voting in seventeen states. ${ }^{1}$ Above all, the Great War, with the stimulation of democratic ideals which has come out of it, has. given a great impetus to the woman's suffrage movement in this country. There is now a joint resolution before the Congress of the United States proposing an amendment to the Constitution which, if adopted, will give to women throughout the United States the same rights of voting as men. The resolution has been passed by the House of Representatives, and, although recently rejected by the Senate, there seems little doubt that it will ultimately be carried into effect. If this should come to pass, the political system of the United States, so far as the right of the people to share in the 1 October, I918. 


\section{THE UNITED STATES}

election of those who exercise governmental power is concerned, will be as democratic as it could well be.

Americans do not as a rule follow closely the work of their various legislatures, or take much interest in the great majority of the laws they make. In a single session of almost any state legislature a thousand or more bills are introduced. Most of these are happily never enacted into law; but very few people indeed ever hear of the majority of those that are enacted into law. Only in those laws which are the result of wide-spread interest and of much discussion in the newspapers do the people take any interest; and on the other hand, aside from a few very special laws, those laws in which the people are not interested cannot long be enforced. In other words, the right to vote for representatives is only one method of expressing the popular will; a less tangible but a much more effective way is through the force of public opinion. Public opinion, when it is once definitely crystallized, can easily force legislatures to make the laws that are desired, and it can with equal ease compel officials to enforce or to ignore any law after it has once been made. In the 


\section{AN EXPERIMENT IN DEMOCRACY}

United States there is no power that can long resist a consolidated public opinion.

But what is public opinion? There are of course many public opinions. Wherever you have a group of people who think alike in respect to any matter, there you have, for that group and in respect to that matter, a public opinion. In respect to many things, there is a public opinion of the village which is different from the public opinion of the city, a public opinion of the city which is different from the public opinion of the state, a public opinion of the state which is different from the public opinion of the nation. Again, in any territorial area, public opinion may differ from class to class and from group to group. There is what may be called the public opinion of the Democrats as opposed (it must be opposed) to that of the Republicans, the public opinion of the laboring class as opposed to the public opinion of the capitalists, the public opinion of the Brewers' Association as opposed to the public opinion of the Women's Christian Temperance Union.

Over large areas these various group opinions often neutralize one another so effectively that the practical result is nil; and it is obvious that the larger the area and the more diverse the groups concerned the more difficult it is ever to get a thoroughly consolidated 


\section{THE UNITED STATES}

public opinion in essential questions of politics and society. This difficulty depends not only upon the size of the territory concerned, but also upon the extent to which there is present vital differences in respect to race, cultural habit, or economic conditions. Kansas is almost entirely an agricultural state in which there are not many very poor or very rich people, no large cities, and few foreign-born citizens. It is therefore much easier for the people of Kansas to agree in respect to most questions of politics than it is for the people of New York State to agree in respect to similar questions. For example, there is a consolidated public opinion in Kansas, and has been for a long time, on the subject of prohibition; there is no such consolidated public opinion on this subject in the state of New York, where there is so little uniformity in respect to the racial origins of the people and in the economic conditions under which they live.

It is obvious, therefore, that the larger a country is, and the more deep-seated the differences are between section and section, or between the different groups and classes, the more difficult it will be to have a consolidated public opinion on most questions of importance. Now the United States is a very large country, with well-marked geographical areas differing in climate, soil, economic con- 


\section{AN EXPERIMENT IN DEMOCRACY}

ditions, and in the characteristics of the people. The Alleghany and the Rocky Mountain ranges divide the country into the East and the Middle West and the Far West; climate and historical memories combine to differentiate the North from the South. The people of the United States are of cosmopolitan origin. For a century a constant stream of foreign immigrants has been pouring into the country, and to-day about one-third of the people are, at least on one side, of foreign-born parentage. To-day it is very difficult to say what is a "typical" American name or a "typical" American face. One is reminded of the story of the corporal who at first had difficulty in calling the roll of his company, on account of the great number of strange Polish and Italian names; but at last he came to the name of O'Shaughnessey, and was heard to mutter under his breath, "Thank God for one of those good old American names." Almost any name is now a good American name. But besides its geographical and racial diversity, America is rapidly becoming an industrialized country, wealth is being rapidly concentrated in the hands of the few, and as a result there is developing, in certain sections especially, a marked divergence of interests and ideas between the capitalist and the laboring classes. In America, therefore, the problem of recon- 


\section{THE UNITED STATES}

ciling sectional differences, of Americanizing the mass of foreign immigrants, of composing the different interests of labor and capitalin a word, the problem of creating a consolidated public opinion is a difficult one.

If, under these conditions, the American system of democratic government works fairly well, it is partly due to the fact that the federal system, with its elaborate scheme of checks and balances, is well suited to a large country with a great diversity of conditions. The federal system is complicated, and it works slowly, but it has this supreme merit, that it does not confer too much authority in any one government, that it allows a great deal of leeway for political experimentation in restricted areas in conformity with the crystallization of public opinion in those areas. The federal system does not require the people of the whole United States to form a consolidated public opinion on every important social or political question, but only upon those questions in respect to which it is essential that the nation should act as a unit. This is only a way of saying that the federal system allows a great deal of liberty in local government-it allows the people of a state, or the people of a city or county, a good deal of liberty todoas they please.

It is said that on one occasion the French Minister of Public Instruction, taking out his 96 


\section{AN EXPERIMENT IN DEMOCRACY}

watch, told his English visitor that at that moment all the children of France of a certain age would normally be studying the same subject out of the same text-book. This could happen only in a country in which a great majority of the people were pretty well agreed as to what children of a certain age ought to be doing at a given hour of the day. No such agreement exists in the United States. Every one is agreed that education is a good thing, that there ought to be more of it, and that it ought to be better than it is. But there is the greatest diversity of opinion, which seems to fluctuate from day to day, as to what kind of education is best; and it would therefore be thought intolerable that the United States government should regulate these matters in a uniform way for the whole country. This is a matter for the state of the locality to determine. If the people of Iowa feel very strongly that a knowledge of Greek is useless in a farming community, the state of Iowa has only to abolish the teaching of Greek from the schools of Iowa. If the people of Gary, which is a highly industrialized city, wish to try a radical experiment in industrial education, why should they not do so? It may turn out well, in which case other cities can adopt it; or it may turn out ill, in which case other cities may profit by the example, while 


\section{THE UNITED STATES}

Gary itself can at any time return to normal ways. And so it is in respect to a hundred questions of government and politics; in respect to woman's suffrage, prohibition, ${ }^{1}$ the regulation of corporations, divorce, city government, municipal ownership of street railways, water-works, and other public utilities-in respect to all such matters particular states and local communities are constantly engaged in political and social experimentation, are constantly solving their own problems according to the pressure of local or regional public opinion.

Where there is so much leeway for the states and localities to manage their own affairs, it is only in matters in respect to which the whole nation has to act as a unit that the people have to form a national opinion; and this is a good thing, for it takes the nation a long time to make up its mind. It took the nation a long time to make up its mind in respect to the Great War. Many people got impatient with the government because it did not declare war sooner. But the government, in a country where public opinion is the ruling power, could not possibly take such a momentous step until the people were ready for it, until a fairly consolidated public opinion had been formed; and under all the circumstances, the wonder is, not that the nation

1 This is no longer true of Prohibition. 98 


\section{AN EXPERIMENT IN DEMOCRACY}

took so long to make up its mind, but that it made it up as quickly and, on the whole, as decisively as it did.

The federal system, with its checks and balances, although it often seems rather slow and clumsy, is nevertheless pretty well adapted to this large and diverse country in which the formation of a national opinion is a slow and often a clumsy process. It is often said that the government of Great Britain responds much more quickly to the pressure of public opinion than the government of the United States does. This is perhaps true, but it is not so true as it seems to be. What seems to be a more ready response to public opinion is often only a more rapid formation of public opinion itself. England is a small countryabout the size of the state of Kansas. The political and industrial and intellectual life of the nation centers in London, where the government sits. The whole country reads the same papers-the London papers-on the same day they are printed; discusses the same events, the same men, the same measures, the same speeches, the same scandals. Nothing like this happens, or can happen, in the United States. Strictly speaking, the United States has no capital, no dominating center of industrial, political, or intellectual life. Particularly, there is no center of intellectual life. 
The last place to go to find out what the people are thinking about is Washington, as President Wilson himself has found out; and it is easier to predict the result of a general election in Kansas City than in New York. East of the Alleghany Mountains the people read the New York, Boston, Philadelphia, or the Washington papers, and they never see any other. In the Middle West the people read the Chicago, Minneapolis, St. Louis, or Kansas City papers. They can't get the New York papers until the day after they are printed, and no one likes to read old news. If you go still farther west - to Seattle, Portland, San Francisco-you are again in a new country, where a New York paper, if one is ever seen, is four days behind the times.

Of course the newspapers all carry much the same press matter; and events of world importance, or of great national significance, are similarly presented, and read on the same day, the country over. But what the people think about these events in any particular section, and how their particular interests are involved - this is differently reflected in the different sections; so that to a considerable extent the people of the different sections read and think about different men and different events and different issues. Under these circumstances it is no wonder that it takes a IOO 


\section{AN EXPERIMENT IN DEMOCRACY}

long time to form a thoroughly consolidated opinion on any vital matter.

It not infrequently happens that the people elect in one year a Republican President and a Republican majority in Congress, but two years later, in the congressional elections, elect enough Democrats to place the Republicans in a minority in Congress. The result seems an absurd one, for then there are two parties, with different ideas and policies, in power, one in control of the executive and another in control of the legislative branch of the government. In that case it would seem that the government could not reflect the will of the people. But it is possible that it reflects it perfectly. It is possible that the country is slowly changing its mind, that it does not yet know certainly what it wants. This is not always the case, but it is often the case; and when it is the case the deadlock in the government is a good reflection of the popular will, or lack of it. At least, until it is certain that the country has thoroughly made up its mind one way or another, it is perhaps not a bad thing for the government to go a bit slow.

\section{VI}

As we look back over American history, it is clear that there has been an ever-increasing ror 


\section{THE UNITTED STATES}

number of questions about which the people, as a whole, have come to think alike, about which a consolidated national public opinion has been formed; and in proportion as this has come about the powers of the federal government have increased and the powers of the state governments have diminished. Whenever the people come to think nationally about any question they usually transfer the control of that question to the national government. The result, after a century and a quarter, is that the power and the prestige of the federal government are enormously increased. If the framers of the Constitution could come back to earth and see what the federal government is doing to-day, they would all agree that this monstrous thing was no child of theirs; for to-day the federal government exercises as a matter of course powers which they never dreamed of giving to it. This result has been the consequence of changing conditions and ideas; it is the result of an ever-increasing nationalism, a constant extension of the sphere of social and political questions in respect to which there is a consolidated national public opinion.

But since we have a written constitution, and the powers of the federal and state governments are defined in the Constitution, how does the federal government acquire new 


\section{AN EXPERIMENT IN DEMOCRACY}

power? The obvious way is, of course, by changing the Constitution, by adopting amendments to it. The Constitution can, however, be amended only when the House of Representatives and the Senate, each by a two-thirds vote, proposes such an amendment, and when this proposed amendment is approved by the legislatures of three-fourths of the states. This would seem to make the amendment of the Constitution extremely difficult, and, in fact, until recently it was generally supposed it would require something like a revolution, something like the Civil War, to get the Constitution amended.

There is, however, another way in which the power of the federal government has been increased, and that is by what is called a "liberal interpretation" of the Constitution. As has been seen, it falls to the Supreme Court to determine whether a statute of the federal government is or is not constitutional; and it is obvious that the power of the federal government can be restricted or extended by the simple process of interpreting the terms of the Constitution as strictly or as liberally as possible. Some of the terms of the Constitution are very elastic in this respect. It will be remembered that after defining the specific powers of Congress, the Constitution says, "And to make all laws which may be necessary and proper for 
carrying into execution the foregoing powers." By a liberal interpretation of this clause the powers of the federal government have been very greatly extended. Through legislative regulation, for example, the federal government exercises control over the railroads and other corporations, a control which may at any time easily pass into public ownership of these corporations; and it has this power because it is a "necessary and proper" power for carrying into execution the harmless-looking power "to regulate commerce between the several states." The Constitution is so elastic that there is almost no limit to the extension of the powers of the federal government by means of judicial interpretation; the only thing necessary is to have a national public opinion which favors the extension. As we say in the United States, "the decisions of the Supreme Court follow the election returns."

But there are some powers which cannot be read into the Constitution, which can be put there only by a formal amendment of the Constitution. And in recent years it has become clear that the formal amendment is a less difficult matter than was formerly supposed. This also is only a matter of getting a sufficiently consolidated national public opinion. Such an opinion in America is likely to come gradually, without a great deal of dis- 


\section{AN EXPERIMENT IN DEMOCRACY}

cussion and without any upheaval; and it is brought about by the constant social experimentation which is going on in the states and local communities far more than by argument and discussion. Americans are but little inclined to take up with ideas or theories simply because they have a logical consistency; but on the other hand they are not inclined to hold to any custom merely because it is old. Their aims are practical and their methods direct; and when any new thing is proposed to them their first question is, "How will it work?" You may say that it is only just that women should have the right to vote, or you may say that to refuse women the vote is inconsistent with the principles of the Declaration of Independence; but what nine men out of ten will ask is: "Why do women need to vote? How will it work out in practice?" Now, it is a great advantage of our federal system that it admits of trying out this new idea on a small scale. For a long time we have been experimenting with woman's suffrage, first in municipal elections, then in one state after another. The average American has accordingly not argued much about woman's suffrage; he has watched it work in one state after another; and as it seems to work well enough, and nothing serious happens where it is tried, the average 105 


\section{THE UNITED STATES}

American finds himself in favor of woman's suffrage without really knowing how. The truth is that he has simply become accustomed to the idea of it, and he finds himself saying, "Well, I suppose women ought to have a right to vote." What he really thinks is: "Woman's suffrage seems to work well enough where it is tried; there seems to be no harm in it. I expect it is bound to come."

When Americans get the idea that a thing is "bound to come," the battle is won. Women will soon have the right to vote throughout the United States because the opinion that "it is bound to come" is taking hold of the country. The same is true of the prohibition movement. This has been an issue in the United States for fifty years; and in some states the manufacture and sale of alcoholic liquors have been prohibited for a generation. The movement has spread rapidly in recent years, until now over half the states are what we call "dry" states. The war has in the mean time given such an impetus to the movement that prohibition, like woman's suffrage, is coming to be regarded as one of the things that "are bound to come." National opinion is already so far crystallized on this question that Congress has voted a constitutional amendment, . which is now before the state legislatures for Io6 


\section{AN EXPERIMENT IN DEMOCRACY}

ratification. It is extremely probable that it will receive the approval of the necessary three-fourths of the states, in which case the power of the states to regulate the manufacture and sale of liquors will once for all cease. ${ }^{1}$

It all comes back to the question of a thoroughly established national public opinion. If the people really want to change the Constitution it is a simple matter to do so. The system of written constitutional guaranties prevents hasty action, and it preserves a great deal of local liberty as long as there is a marked divergence of interests and ideas throughout the country in respect to any question; but there is nothing in the system of written constitutions or in the system of federal government to prevent the popular will, when it is once certain what the popular will is, from having its way. If its way leads to an ever greater degree of equality in the distribution of wealth, if the popular will is bent upon establishing a genuine social democracy, there is no power either in men or in institutions to prevent the achievement of these ends.

1 This proposed amendment nas, since the above was written, been ratified by the necessary three-fourths of the states. 


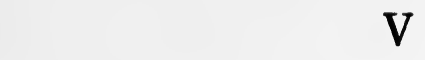

NEW WORLD DEMOCRACY AND OLD WORLD INTERVENTION

THE first years of independence were taken 1 up with attempts to solve the many problems of peaceful reconstruction under a federal government which was one of the weakest ever devised by the hand of man. By 1786 all far-sighted men realized that a stronger bond of union would have to be created if the United States were not to dissolve into thirteen completely independent republics; and the movement for strengthening the Articles of Confederation resulted in the Constitutional Convention of 1787 which formulated the present Constitution. Within the next two years the Constitution was referred to the several states for ratification, and in 1789 the new government went into operation with the inauguration of George Washington as the first President. It was essentially over the quesI08 


\section{AN EXPERIMENT IN DEMOCRACY}

tions giving rise to the formation of a new Constitution, and over the question of the new Constitution itself and of its approval or rejection, that the people gradually divided into two chief political parties. Those who were in favor of the new Constitution were called Federalists because they wished for a more effective federal union of the states; those who opposed the adoption of the Constitution were at first called Anti-Federalists, but later, after the Constitution was in fact adopted, they called themselves Democratic Republicans. Washington, Alexander Hamilton, and John Adams were the spokesmen of the Federalists, while Thomas Jefferson was for many years the acknowledged and undisputed leader of the Republicans.

Both the Federalists and the Republicans were anti-monarchical. Both accepted the idea of self-government as it had been practised in the Colonies, and both accepted the Revolution as having forever put an end to hereditary kings and a hereditary nobility in America. But they differed in their respective attitudes toward popular government, its sources of strength and of weakness, and the limitations which should be placed upon it. The Republicans were what would to-day be called a radical party, the Federalists a conservative party. Hamilton had little faith 


\section{THE UNITED STATES}

in the virtue or the wisdom of "the people," and none at all in their capacity for efficient government. According to him only the people with property had a sufficient interest in good government to be intrusted with political power. He thought that the propertied classes, in defense of their property, would be the surest bulwark against the double danger of autocracy and anarchy, and in general the fact that a man possessed property was likely to be an evidence of industry, thrift, and intelligence. The mass of the people, if they were given power, having nothing to lose, would be keen for depriving others of that which they had themselves never been sufficiently industrious or intelligent to acquire. Hamilton therefore believed in government for the people by the most intelligent and prosperous people.

Many Federalists were not so frank as Hamilton in expressing their views, but they all shared his anti-democratic philosophy. The experience of the Revolutionary War and the years immediately following had made many men more conservative than they had once been. John Adams's enthusiasm for a republic founded on virtue had greatly cooled, and the fear of revolution replaced in his later years the fears of tyranny which had inspired him in middle age. Especially after the French 


\section{AN EXPERIMENT IN DEMOCRACY}

Revolution had run its course, proclaiming the Terror and the de-Christianization of France, proclaiming the mission of the republic to carry the blessings of liberty and equality to all nations, conservative and conventional people everywhere came to fear revolution as a dangerous and insidious menace to established order. In their minds the word "revolution" aroused the same repulsion that the word "bolshevism" arouses in our day-it was synonymous with anarchy in government and with atheism in religion.

At the opening of the nineteenth century the "upper classes" in every European country shared these views. The Federalists were the people in America who shared them because the Federalists were for the most part the well-to-do. The strength of the Federalists was greater in New England than in the South, greater in the centers of trade and industry than in the farming districts, greater among the educated than among the uneducated, greater among the rich than among the poor. The Federalists therefore voted for the Federal Constitution and were in favor of enlarging the functions of the federal government, not only because a strong federal government would serve the economic interests of the industrial and moneyed classes, but also because it would be less amenable to popular 


\section{THE UNITED STATES}

control than state governments had been, and would serve as a needed check upon such radical political tendencies as might find expression in certain parts of the country. The dangerous ideas of Thomas Jefferson might gain complete ascendancy in Virginia, but as long as the Federal Constitution held, the state of Virginia would never be able to carry out a program that involved anything so revolutionary or Jacobinical as "impairing the obligation of a contract."

The bad odor of the word "revolution" was easily communicated to the word "republican," since it was the French Republic that inaugurated the Terror and made the name of revolution hateful. Therefore the Federalists feared Jefferson and his "Republican" followers not only because they professed to have entire faith in the capacity of the people for government, but because they still retained the sympathy with the revolutionary movement in France which nearly every one had expressed in the days before the Terror. The fear was genuine enough in most cases, but it was also good politics to fasten upon their opponents the terrible names "Jacobins" and "atheists," and to denounce them as men who desired to destroy government, confiscate property, and abolish morality.

The bitterness with which the Federalists 


\section{AN EXPERIMENT IN DEMOCRACY}

attacked Jefferson, the solemn confidence with which they assured the public that the Republicans were the desperate and determined enemies of the human race, is almost incredible. July 7, I80I, after the inauguration of Jefferson as President, Theodore Dwight, an intelligent and educated New England Federalist, delivered an address in which he gave vent to the following sentiment:

The great object of Jacobinism, both in its political and moral revolution, is to destroy every trace of civilization in the world and force mankind back into a savage state. We have now reached the consummation of democratic blessedness. [He is referring to the election of Jefferson.] We have a country governed by blockheads and knaves; the ties of marriage with all its felicities are severed and destroyed; our wives and daughters are thrown into the stews; our children are cast into the world from the breast and forgotten; filial piety is extinguished, and surnames, the only mark of distinction among families, are abolished. Can the imagination paint anything more dreadful on this side of hell?

It would indeed have been difficult for the imagination, even of an excited New England Federalist, to paint anything more dreadfulor anything more remote from the wishes or the purpose of the humane and kindly leader of the Republican party. Thomas Jefferson, the author of the Declaration of Independence, 


\section{THE UNITED STATES}

still held to the doctrine that "all men are created equal," and never lost his faith in those ideals of popular government and republican virtue, of the innate goodness of man, of the regenerative power of simple and genuinely democratic institutions, which were proclaimed by the generous minds of the eighteenth century, and which furnished the driving force of the American and French revolutions. In spite of the failure of both revolutions to realize these ideals in any perfect way, in spite of the disillusionment which swept so many honest men into reaction, Jefferson remained a democrat. He believed in government of the people, for the people, and by the people.

The Republicans were those who on the whole followed Jefferson. They retained their early republican faith. They looked at the question of government from the point of view of the pursuit of happiness rather than from the point of view of the maintenance of security, and were more concerned for the rights of men than for the protection of property. Accordingly, they would have government frankly responsive to the popular will, freed from the control of any "upper class," either of birth or wealth or education. They would have government as simple as possible, limited to the protection of life and property. 


\section{AN EXPERIMENT IN DEMOCRACY}

For all of these reasons they had mostly opposed the new Constitution, and when it was once adopted they wished to restrict the functions and powers of the federal government as much as possible, and to preserve to the people of each state all the essential powers of sovereignty. In those days of difficult communication, the Jeffersonian Republican felt that only a government that was close at hand could be properly watched, and only a government that was limited to a small territory could retain a primitive and arcadian simplicity; a government in the distant city of New York or Washington, with extensive jurisdiction over the whole country, was likely to develop into a complicated bureaucracy as open to intrigue and as difficult to control as the most hateful monarchy of Europe.

Monarchy! This, after all, so the Republicans professed to believe, was what the Federalists secretly wanted. They were aiming at the destruction of republican liberty. Did they not openly denounce the French Republic and all its works? Did they not openly sympathize with the British government, that very power which had so long endeavored to enslave America? Did they not openly profess a contempt for the "mob," the "canaille"? What could this mean except that these so-called Federalists were in their 


\section{THE UNITED STATES}

hearts aristocrats, monarchists in disguise, who were waiting for the day when with the aid of British gold they could proclaim the Kingdom of America and have themselves made Dukes of New York and Earls of Boston? The imagination of the Republican journalists was as active as that of Theodore Dwight, and in their vilification of Hamilton and Adams, and of Washington himself, they exhausted the rich sources of the English language. No human motive was too low or sordid or cowardly to be imputed to these onetime patriots and heroes.

The profound gulf which separated the two groups of the American people in the early years of the Republic is a point of first-rate importance. It is true that the vile names which Federalists and Republicans flung at each other were often enough no more than the engaging amenities of party politics. But the mutual hatred of the two parties had also its solid foundation in a genuine fear. Each party feared that the other was un-American. Each party feared that the other was so entangled with certain European influences that its success would destroy American institutions. The Republicans feared that the Federalists were so tied to Great Britain that they were ready to undo the work of the Revolution; the Federalists feared that the Repub- 


\section{AN EXPERIMENT IN DEMOCRACY}

licans were so infected with French Jacobinism that they were ready to proclaim the Terror and plunge America into the confusion created by Robespierre and exploited by $\mathrm{Na}$ poleon. The profound and apparently irreconcilable hostility which threatened to shipwreck the New World experiment in democratic government was primarily due to the connection which still existed, or was supposed to exist, between American and European politics. Able men on both sides of the ocean believed that the United States must surrender either its independence or its free government; that its 'feeble government must either give place to a strong monarchy or in self-defense be drawn into the system of European alliances and so lose the better part of independence. For a generation the history of the United States centered in this issue. The future of the American experiment in democracy depended upon its being freed from the entanglements of European politics and the danger of European intervention.

For a hundred years before the Colonies won their independence from Great Britain they had been drawn into every European war, with or without their consent, whether or not their essential interests were involved. In his famous pamphlet entitled Common Sense Thomas Paine pointed out that one 


\section{THE UNITED STATES}

advantage of independence from Great Britain would be the consequent freedom from European quarrels and conflicts.

We have boasted the protection of Great Britain, without considering that her motive was interest, not attachment; and that she did not protect us from our enemies on our own account, but from her enemies on her own account, and from those who have no quarrel with us on any other account, and who will always be our enemies on the same account. [Therefore] our duty to mankind at large, as well as to ourselves, instructs us to renounce the alliance: because, any submission to, or dependence upon, Great Britain tends directly to involve this continent in European wars and quarrels, and sets us at variance with nations who would otherwise seek our friendship and against whom we have neither anger nor complaint.

This was certainly true in part, and might conceivably have proved altogether true had peace prevailed in Europe for another generation. But, as it turned out, the French Revolution followed hard upon the American War of Independence; and the French Revolution gave rise to a series of general European wars which began in 1792 and lasted almost without cessation until I8I5. In these wars France, first under the Republic and afterward under the leadership of Napoleon, was pitted against all the great powers of Europe. The immediate causes of these wars were vari- 


\section{AN EXPERIMENT IN DEMOCRACY}

ous, but the underlying issue in the earlier period was the conflict between the democratic ideals of revolutionary France and the old-régime ideals of the monarchical states, and in the later period between these same states and the revolutionary and aggressive imperialism of Napoleon. Throughout the period of these wars France, in times of reverse, claimed to be fighting for national independence, and in times of victory for the spread of a higher civilization among the backward nations of Europe. The allies, on the other hand, claimed to be fighting in defense of small nations and for the preservation of civilization, and they declared their intention to continue the war until they had destroyed, not, indeed, the French people, but the intolerable menace of the revolutionary spirit and of the ruthless militarism which was the instrument of its propagation. From the beginning England was the organizer of all the coalitions, and in the end the great conflict was essentially one between the continental power of Napoleon and the sea power of the British Empire.

When the world war became general, in I793, President Washington proclaimed the neutrality of the United States. But neutrality was easier proclaimed than maintained in respect to a war in which all Europe engaged, which involved the colonial possessions 


\section{THE UNITED STATES}

of England, France, Holland, and Spain, and which was fought out on every sea. The difficulty was all the greater because the War of Independence had left its heritage of obligations to France and of undissolved contacts with England. As a price of French aid the United States had bound itself, by the Treaty of Alliance of $\mathrm{I} 778$, to guarantee "forever against all other powers ... to His Most Christian Majesty the present possessions of the Crown of France in America." The treaty of amity and commerce of the same year accorded to France special commercial favors and the right to carry French prizes into American ports. On the other hand, Great Britain still refused to surrender the military posts in the Northwest on the ground that the United States had refused to indemnify the Loyalists according to the Treaty of I783. Therefore, while France counted confidently upon the United States to repay its old debt by coming to her aid, England used her naval power to force the United States to renounce the French commercial treaty and conspired with Spain to recover the territory west of the Alleghanies.

Under these circumstances, to proclaim neutrality and take the side of neither party was to incur the enmity of both; and it was not to be supposed that either belligerent 


\section{AN EXPERIMENT IN DEMOCRACY}

would respect the neutral rights of a debtridden and divided country which would be a negligible factor even if it went to war. It is true that by going to war the United States could at least preserve its "honor." But it was exceedingly unlikely that it could enforce its rights against either belligerent by joining the other. In any case, which side should it join? Its neutral rights were equally violated by England and France, and while the Federalists were keen for war against France, the Jeffersonian Republicans were keen for war with Great Britain. By entering actively into the European conflict, the United States might preserve a semblance of honor, but it was almost certain that it would lose everything else. By entangling itself in the European system of alliances and pledging itself to stand or fall by a European treaty the United States would have compromised the revolutionary settlement of 1783 , invited its own people to engage in civil war, and placed the feeble Republic in tutelage to the great powers of Europe.

President Washington was far-sighted enough to see that the great end to be attainedthe great end both for America and for the world-was the preservation of the federal Union as the only hope for the continued existence of free institutions. He preferred to suffer 


\section{THE UNITED STATES}

repeated humiliation rather than, as the price of national "honor," to bring the promising experiment in democracy to an untimely end. In his famous "Farewell Address" he accordingly gave classic expression to the policy which the United States ought to pursue in regard to European politics, as well as to the motives which justified it.

The great rule of conduct for us, in regard to foreign nations, is, in extending our commercial relations, to have with them as little political connection as possible. ... Europe has a set of primary interests, which to us have none, or a very remote relation. Hence she must be engaged in frequent controversies, the causes of which are essentially foreign to our concerns. Hence, therefore, it must be unwise in us to implicate ourselves, by artificial ties in the ordinary vicissitudes of her politics, or the ordinary combinations and collisions of her friendships or enmities. ... If we remain one people, under an efficient government, the period is not far off when ... belligerent nations, under the impossibility of making acquisitions upon us, will not lightly hazard the giving us provocation; when we may choose peace or war, as our interests guided by justice shall counsel. Why forego the advantages of so peculiar a situation? ... Why, by interweaving our destiny with that of any part of Europe, entangle our peace and prosperity in the toils of European ambition, rivalship, interest, humor, or caprice?

It is clear that Washington did not urge his countrymen to adopt a policy of complete isolation; on the contrary, he urged them to 


\section{AN EXPERIMENT IN DEMOCRACY}

cultivate relations with Europe in every respect save one-the political relation. He would have the United States keep free of political alliances. If we would understand why Washington so strongly urged this policy we must read the entire "Farewell Address." Only a small part of that address is devoted to this point, which is the only part that is often quoted. The principal part of the address is concerned with those evils which threatened to dissolve the Union and to place the stamp of failure on the newly established federal government. To prevent this greatest of calamities he urged his countrymen to renounce those class enmities and sectional and party rivalries that were likely to weaken the union of the states; and it was precisely because he felt that entangling alliances abroad would endanger the Union and undermine free government that he wished to avoid such alliances.

How many opportunities do they [exaggerated attachments or hostilities to foreign nations] afford to tamper with domestic factions, to practise the arts of seduction, to mislead public opinion, to influence or awe the public councils!... Against the insidious wiles of foreign influence, I conjure you to believe me, fellowcitizens, the jealousy of a free people ought to be constantly awake, since history and experience prove that foreign influence is one of the most baneful foes of Republican Government. But that jealousy to be useful 


\section{THE UNITED STATES}

must be impartial; else it becomes the instrument of the very influence to be avoided, instead of a defense against it.

The policy of Washington was followed in its essential points throughout the Napoleonic wars. It is true that the United States found it necessary upon two occasions to abandon its positions of neutrality. The first instance was in 1798, during the Presidency of John Adams, when the grievances against France became intolerable. Washington's statement that "foreign influence is one of the most baneful foes of Republican Government" was never more in point than at this time. French agents in the United States were intriguing for the success of the Republican party, and they convinced the French government that the Federalist President was unsupported by the people: "The friends of liberty in the United States, supported by the great part of the House of Representatives, will probably not wait for the next elections, but in the mean time will destroy the fatal influence of the President-by a revolution." Counting upon this supposed pro-French sentiment, the French government at last endeavored to bribe the American ambassadors, whereupon the President severed diplomatic relations and prepared for war.

The French government wanted support 


\section{AN EXPERIMENT IN DEMOCRACY}

instead of war, and when it discovered that the people of the United States were prepared to back the President rather than to overthrow him peace was quickly restored. But the significant point in this episode is that President Adams, although forced to renounce neutrality, was careful to avoid committing the United States to any European alliances. The very spirit of Washington's "Farewell Address" speaks in the memoir which Adams presented to his Cabinet in January, I798:

Will it not be the soundest policy, even in case of a declaration of war on both sides, between France and the United States, for us to be totally silent to England, and wait for her overtures? Will it not be imprudent in us to connect ourselves with Britain, in any manner that may impede us in embracing the first favorable moment to make a separate peace? What aids or benefits can we expect from England by any stipulations with her, which her interest will not impel her to extend to us without any? On the brink of the dangerous precipice on which she stands, will not shaking hands with her necessitate us to fall with her, if she falls? On the other hand, what aid could we stipulate to afford her, which our own interest would not oblige us to give without any other obligation? In case of a revolution in England, a wild democracy will probably prevail for as long a time as it did in France; in such case, will not the danger of reviving and extending that delirium in America be increased in proportion to the intimacy of our connection with that nation? 


\section{THE UNITED STATES}

Although peace was restored with France, the neutral position of the United States became more and more difficult to maintain as the great conflict between Napoleon and the British Empire reached its height. Thomas Jefferson, who declared in the spirit of Washington in favor of "peace with all nations, entangling alliances with none," refused to declare war even in the face of the most flagrant violation of neutral rights on the part of both England and France. To compel a recognition of those rights, he resorted to commercial warfare, laying an embargo upon all American commerce with both belligerents. The embargo proved a vain measure, and at last the United States once more resorted to war to enforce its neutral rights. Our grievances against France were not less than those against England, but James Madison, the Republican successor of Jefferson, chose, for reasons that are obscure to this day, to make war on England. Nevertheless, he followed the precedent of John Adams in carefully refraining from allying the United States with Great Britain's enemy. For two years the United States carried on the war on its own hook, and the peace which it made in 1814 was no part of the great European settlement which was then already in process of being effected. 


\section{AN EXPERIMENT IN DEMOCRACY}

Referring to the negotiations between the American and British ambassadors at Ghent, Pozzi di Borgo wrote these significant words to Nesselrode on August 9, 1814:

The conclusion of this important matter is uncertain. The dominant party in America, which desired the war, is aiming at a complete revolution in the relations of the New World with the Old, by the destruction of all European interests in the American continent.

The War of 1812 is sometimes called the second war of American independence. It is in fact no exaggeration to say that the years I 8I4-I5 ended the dependence of the United States not only upon Great Britain, but upon Europe as well.

The Treaty of Ghent, the overthrow of Napoleon, and the European settlement of the Congress of Vienna were welcomed by the people of America with universal joy. For a quarter of a century the tremendous upheaval in the Old World had disturbed the peace and threatened the very existence of the United States. The war with England had not been a brilliant success, but it had not been a failure, and the record in the war and the terms of the peace were such as a young nation, 


\section{THE UNITED STATES}

which for twenty years had been treated with contemptuous insolence, might regard as a vindication of its rights and a justification for self-respect. With Napoleon at St. Helena and the powers desirous of peace at all hazards, the people of the United States, with an immense sigh of relief, turned their backs on the Old World and its affairs and with buoyant enthusiasm took up their proper task - the development of those inexhaustible resources that would one day make them great and powerful.

Buoyant enthusiasm and unlimited selfconfidence were indeed the characteristic note in the United States during the decade after I8I5. The Napoleonic wars had contributed immensely to the industrial and commercial prosperity of the country, and the financial situation of the government was excellent in spite of the expenses of the War of I8I2. But, above all, the old internal dissensions. between Federalists and Republicans had disappeared. The country was thoroughly wedded to its institutions, and no one any longer feared the monarchical inclinations of a pro-British party or the Jacobinism of a proFrench party. There were indeed no longer any pro-British or pro-French parties. All parties were thoroughly American. The country had found itself; it knew well that it was no mere appendage of Europe; and it I 28 


\section{AN EXPERIMENT IN DEMOCRACY}

was determined at all hazards that Europe should recognize the fact.

The consciousness that the United States was destined to run a different course than Europe was strengthened by contemporary events in South America. When Napoleon overturned the Bourbon monarchy in Spain, the Spanish colonies took advantage of the opportunity to throw off their allegiance to the mother country, and, in imitation of the British colonies a generation earlier, they organized their governments on the republican model of the United States. By 1820 the de facto South American republics had virtually won their independence, and, like the United States, they wished only to go their own way freed from European tutelage. The United States, naturally enough, was prompt to give formal recognition to these new sister republics; of the superiority of republican institutions she could not doubt, and it was for her an immense satisfaction to think of the entire New World as the home of freedom.

The Old World was less pleased with such a prospect. To the ruling classes in Europe, Napoleon was (what he called himself) the "child of the Revolution," and to the ruling classes the "Revolution" was therefore responsible for twenty-five years of political insecurity and of desolating war. After 1815 the chief 


\section{THE UNITED STATES}

aim of the principal states was to prevent a repetition of the stupendous conflicts which had characterized the Napoleonic era. To preserve the peace of Europe, in the opinion of Metternich, who was the guiding spirit, at least after I8I8, of the Concert of Europe, it was necessary to maintain the existing political system. The chief danger to the existing political system was manifestly those republican theories spread abroad by the American and French revolutions. It was, therefore, the duty of the great powers to act in concert in the suppression of all revolutions intended to propagate or establish republican institutions. On these grounds revolutions in Italy were suppressed by Austria, and France was given a free hand in restoring the Bourbons to the Spanish throne.

If republican institutions were a menace to the peace and good order of Europe, the rulers of the great powers manifestly could not contemplate the spread of those institutions in America without misgiving. The King of Spain, once restored to his throne, therefore "seriously turned his thoughts to the fate of his American dominions." The powers were accordingly notified that

the king has resolved upon inviting the cabinets of his dear and intimate allies to establish a conference at Paris, to the end that their plenipotentiaries ... 


\section{AN EXPERIMENT IN DEMOCRACY}

may aid Spain in adjusting the affairs of the revolted countries of America. . . . His Majesty ... hopes that they will assist him in accomplishing the worthy object of upholding the principles of order and legitimacy, the subversion of which, once commenced in America, would presently communicate to Europe.

It was no longer, as it had been in 1795, a question of European intervention in the affairs of the United States, but a question of whether the European powers, having assumed the duty of regulating European affairs in harmony with monarchical principles, were to be permitted to regulate the affairs of any. part of America in harmony with these principles. Under these circumstances, the United States still refused to become implicated in the European system of alliances, or to take any part in regulating the affairs of Europe; but in addition to this, it now proclaimed a new principle which was but the complement of the old. Since the political system of Europe was monarchical while that of America was republican, the United States would take no part in regulating the political affairs of Europe, and it would therefore expect the European powers to take no part in regulating the political affairs of America.

The first part of this double policy was clearly stated by John Quincy Adams in I820, in an interview with Stratford Canning, the 


\section{THE UNITED STATES}

English Minister to the United States. The English government had invited the United States to take part in the Congress of Toppau, and in reply to this invitation Secretary Adams said that

the European alliances... had ... regulated the affairs of all Europe without ever calling the United States to their consultations. It was best for both parties that they should continue to do so; for if the United States should become a member of the body they would ... bring to it some principles not congenial to those of the other members, and those principles would lead to discussions tending to discord rather than to harmony.

The corollary to this principle was obvious; • if the United States would bring to a European congress "some principles not congenial to those of the other members," it was equally true that the European powers, if they should assume to regulate American affairs, would bring to that business principles not congenial to the United States. Certainly America had as valid a right to become republican if it wished to as Europe had to remain monarchical; and republicanism was no more dangerous to the peace of Europe than monarchism was to the peace of America. In view of the threatened intervention of the European powers in South America, an intervention based avowed- 


\section{AN EXPERIMENT IN DEMOCRACY}

ly upon hostility to republican institutions, President Monroe formulated in his message of 1823 the policy (the policy was that of John Quincy Adams more than that of the President) which has ever since been known as the Monroe Doctrine:

In the wars of European powers [the President said], in matters relating to themselves we have never taken any part. ... O Our policy in regard to Europe .... is not to interfere in the internal concerns of any of its powers; to consider the Government de facto as the legitimate government for us; to cultivate friendly relations with it, and to preserve those relations by a frank, firm, and manly policy, meeting, in all instances, the just claims of every power; submitting to injuries from none. [On the other hand] With the movements in this hemisphere we are, of necessity, more immediately connected, and by causes which must be obvious to all enlightened and impartial observers. The political system of the allied powers is essentially different in this respect from that of America. This difference proceeds from that which exists in their respective governments. And to the defense of our own, which has been achieved by the loss of so much blood and treasure, and matured by the wisdom of their most enlightened citizens, and under which we have enjoyed unexampled felicity, this whole nation is devoted. We owe it, therefore, to candor, and to the amicable relations existing between the United States and those powers, to declare that we should consider any attempt on their part to extend their system to any portion of this hemisphere as dangerous to our peace and safety. With the existing colonies or dependencies 


\section{THE UNITED STATES}

of any European power we have not interfered and shall not interfere. But with the governments who have declared their independence, and maintained it, and whose independence we have, on great consideration and on just principles, acknowledged, we could not view any interposition for the purpose of oppressing them, or controlling in any other manner their destiny, by any European power, in any other light than as the manifestation of an unfriendly disposition toward the United States.

The essential point of the Monroe Doctrine was that, in defense of those democratic institutions to which America was committed, the United States would oppose the extension of the European political system to this continent. The most notable attempt to extend the political system of Europe to America occurred during the Civil War, when Emperor Napoleon III, by means of the French army, established an Austrian prince in Mexico on the ruins of her former republican institutions. Against this enterprise the United States protested vigorously, and the grounds of this protest were clearly stated by Secretary Seward in 1865 :

The real cause of our natural discontent is, that the French army which is now in Mexico is invading a domestic republican government there which was established by her people . . . for the avowed purpose of suppressing it and establishing upon its ruins a foreign monarchical government, whose presence there, 


\section{AN EXPERIMENT IN DEMOCRACY}

so long as it should endure, could not but be regarded by the people of the United States as injurious and menacing to their own chosen and endeared republican institutions. . . . The people of every State on the American continent have a right to secure for themselves a republican government if they choose, and ... interference by foreign states to prevent the enjoyment of such institutions deliberately established is wrongful, and in its effects antagonistical to the free and popular form of government existing in the United States.

The United States has thus defended the less powerful states of America from European intervention; but these less powerful states might well ask, and have sometimes asked, what guaranty they could have against intervention from the United States herself. They might well ask whether the United States was not interested in preventing the European powers from extending their political system to South America in order that her own political influence might be extended there. The conduct of the United States has too often justified this fear. The unjustifiable war with Mexico in 1846 was the most notable example of those instances in which the United States has employed its greater power to further its own interests at the expense of weak neighbors. But on the whole, the United States has not greatly abused its assumed position of supremacy in the affairs of the 10 


\section{THE UNITED STATES}

American continents, and President Wilson has taken repeated occasion to reassure the small states of America in respect to the future policy of the United States. Above all, his Mexican policy has been based frankly upon the principle that the people of Mexico may look to the United States for protection against European interference without fearing that she will herself interfere in their affairs. His attitude was clearly expressed in an address delivered on January 8, 1915 :

I hold it as a fundamental principle, and so do you, that every people has the right to determine its own form of government; and until this recent revolution in Mexico, until the end of the Diaz régime, 80 per cent. of the people of Mexico never had a "look-in" in determining who should be their governor or what their government should be. Now, I am for the 80 per cent. It is none of my business, and it is none of your business, how long they take in determining it. It is none of my business and it is none of yours how they go about the business. The country is theirs. The government is theirs. The liberty, if they can get it, and God speed them in getting it, is theirs. And so far as my influence goes while I am President nobody shall interfere with them....

Do you suppose that the American people are ever going to count a small amount of material benefit and advantage to people doing business in Mexico against the permanent happiness of the Mexican people? Have not European nations taken as long as they wanted and spilled as much blood as they pleased 136 


\section{AN EXPERIMENT IN DEMOCRACY}

in settling their own affairs, and shall we deny that to Mexico because she is weak? No, I say! I am proud to belong to a strong nation that says: "This country, which we could crush, shall have just as much freedom in her own affairs as we have. If I am strong, I am ashamed to bully the weak. In proportion to my strength is my pride in withholding that strength from the oppression of another people."

An episode in recent years which might well give the states of South America reason to fear the United States occurred in connection with the construction of the Panama Canal. In order to build that long-delayed and highly desirable highway to the Pacific, it was necessary to obtain a concession from the state of Colombia. The state of Colombia, doubtless desiring to make as good a bargain as possible, refused to ratify a treaty which had been negotiated; whereupon the government of the United States encouraged, if it did not instigate, a petty revolution in that country, and hastened overnight to recognize the new Republic of Panama, from which the concession for the canal was at once obtained. The state of Colombia has sought, but so far has not obtained, any redress in the matter; but a treaty providing for compensation has long been before the Senate of the United States, and in his address to Congress in December, I9r8, President Wilson urged upon 


\section{THE UNITED STATES}

the Senate the ratification of the treaty. Certainly the compensation provided in the treaty is the least the United States should rightly do to make good an act that can only be described as high-handed aggression against a weak neighbor.

The Panama episode is one of many which make it impossible to maintain that the United States has invariably acted with chastened purposes and worthy aims, or that it has never invoked the Monroe Doctrine except for the disinterested and ideal purpose of defending democratic institutions. Nor can it be denied that the policy embodied in the Monroe Doctrine has been an expression of our material interests. The Monroe Doctrine is based upon material interests precisely as much or as little as democracy itself. It may be safely said, however, that in the crucial instances of the formulation of the Monroe Doctrine one essential and determining influence has been the incompatibility of European and American political institutions and ideals, and fundamentally our policy has been to protest against the extension of the European political system to America because, on account of the incompatibility, such an extension would endanger our institutions as well as our interests. In this sense, the Monroe Doctrine has been the expression of that 


\section{AN EXPERIMENT IN DEMOCRACY}

most deep-seated of American instincts, the attachment to free government and democratic social institutions. It is as if we had . said to Europe: "We are bound that this great experiment in democracy shall have a fair chance. It may fail in the end. If so, let it at least be clearly demonstrated that the failure is due to inherent weaknesses and not to external interference. We propose, if it be a possible thing, to make this part of the world, at least, safe for democracy."

It is an interesting fact that the Monroe Doctrine has never been so much discussed as during the last twenty-five years. Nor has there ever been so little agreement in respect to its meaning and purpose. The reason for this is obvious: on the one hand, most European countries have themselves adopted democratic institutions, and in so far as they have done so the great objection to the extension of the European political system to America falls to the ground; on the other hand, the economic, commercial, and financial interdependence of all countries throughout the world has so immensely increased in recent years that the United States can less easily than formerly refrain from playing her part in the affairs of a world in which the interests of every nation are intimately linked with the interests of all. 


\section{THE UNITED STATES}

The Great War has revealed this fact in all its dramatic possibilities. And there is something to be said for President Wilson's contention that in entering the war against Germany we were not abandoning the Monroe Doctrine, but only making a wider application of it. For a hundred years we asked, and not in vain, that Europe should leave America free to try the great experiment in selfgovernment. When the better part of Europe became engaged in a desperate and uncertain struggle for the preservation, as it seemed, of those very ideals of which the United States had hitherto been the professed champion, how could the United States abandon the Monroe Doctrine more completely than by refusing to take part in making the world, and therefore America, "safe for democracy"? There is something to be said for this idea, but there are two qualifications of vital importance to be insisted upon. In entering the war the United States needed to be quite sure, and in guaranteeing the peace she needs to be quite sure, that it is democracy and not capitalistic imperialism that the world is being made safe for. She needs also to be quite clear that making the world safe for democracy is not the same thing as imposing upon the world her own brand of democracy.

Whether we abandon or maintain the Mon- 


\section{AN EXPERIMENT IN DEMOCRACY}

roe Doctrine is less important than whether we hold fast to or depart from our profoundest traditions. We shall certainly depart from them if, having for a hundred years in the name of democracy defended the right of American peoples to govern themselves in their own way; we now, in behalf of "law and order," deny that right to any European people because they choose to govern themselves according to democratic forms that are not agreeable to us. To raise an army in defense of Belgium and France against German aggressions may well have been no more than a wider application of the Monroe Doctrine; but to send American soldiers into Russia for the suppression of the soviet government of Lenine is indeed to abandon the Monroe Doctrine for the ideals and the methods of the "Holy Alliance." 


\section{VI}

\section{DEMOCRACY AND FREE LAND}

3. This land grows weary of her inhabitants, so as man, who is the most precious of all creatures, is here more vile and base than the earth we tread upon, and of less price among us than a horse or a sheep; masters are forced by authority to entertain servants, parents to maintain their own children. All towns complain of the burden of their poor, though we have taken up many unnecessary, yea unlawful trades to maintain them. And we use the authority of the law to hinder the increase of people as urging the execution of the state against cottages and inmates, and thus it is come to pass that children, servants, and neighbors (especially if they be poor) are counted the greatest burden which if things were right would be the chiefest earthly blessing.

4. The whole earth is the Lord's Garden and He hath given it to the sons of men, with a general condition (Gen. i:28). Increase and multiply, replenish the earth and subdue it, which was again renewed to Noah; the end is double, moral and natural, that man might enjoy the fruits of the earth and God might have his due glory from the creatures. Why then should 


\section{AN EXPERIMENT IN DEMOCRACY}

we stand here striving for places of habitation (many men spending as much labor and cost to recover or keep sometimes an acre or two of land as would secure them many hundred as good or better in another country) and in the mean time suffer a whole continent, as fruitful and convenient for the use of men to lie waste without any improvement?

Such were the third and fourth headings in the brief list of reasons in favor of settling in America which John Winthrop, the leader of the European migration to Massachusetts, wrote down about the year 1628. It was, in its way, a prophetic document. America has indeed been a kind of Garden of the Gods. "Increase and multiply, replenish the earth and subdue it." This might stand as a text of which the entire history of the United States is hardly more than a proper amplification. In America men have never had to "stand-striving for places of habitation." On the contrary, the United States has always had, until very recently, more land than it could use and fewer people than it needed; and this is not only the fundamental economic difference between the United States and European countries, but it is a condition which has more influence than any other in determining the course of American history and in molding that complex force which we call American national character. 


\section{THE UNITED STATES}

"America is opportunity," as Emerson said. No phrase so well expresses what the United States has stood for, both to its own citizens and to the outcast and the dispossessed of the Old World; and the solid foundation of this unrivaled opportunity has been the existence of an extensive public domain of great fertility which the government of the United States has opened freely to the men of all nations. How this public domain was acquired and disposed of, and how it has shaped American institutions and ideals, is an essential part of the story of American democracy.

It was mainly a series of fortunate accidents that placed the public domain under the control of the federal government instead of the individual states. Originally, the title to the land in the New World was legally understood to be vested in the king by right of discovery, and the original grants of territory were made, in most cases, to individuals, such as William Penn, or to corporations, such as the Virginia Company, or the Company of Massachusetts Bay, who undertook to ẹstablish colonies within the limits of the territory granted in each case, with the privilege of subletting the 


\section{AN EXPERIMENT IN DEMOCRACY}

land within their respective grants. The terms of these charter grants to the corporation or to the individual "proprietor" therefore came to be taken as defining the "boundaries" of the colonies which were established within these grants. These terms were sometimes extremely ambiguous, as in the case of Virginia, and often more generous than was intended. The Connecticut charter defined the limits of that colony as extending from "Narragansett Bay on the east to the Southern Sea on the west part." The Carolina proprietors were given the territory between $29^{\circ}$ and $36^{\circ} 30^{\prime}$ " as far as the South Seas." The territory of Virginia was defined as extending two hundred miles on either side of Old Point Comfort, and as including "all that space and circuit of land lying from the seacoast of the precincts aforesaid, up into the land throughout from sea to sea, west and northwest."

All of these grants were made in the belief that the South Sea (Pacific) was not very far away. The common idea was that a way to it could be readily found by following up the coast rivers. As late as 1689 , the governor of Virginia, Sir William Berkeley, still had faith "to make an essay to do his Majesty a memorable service, which was to go to find out the East India Sea,' by sending a small expedition up the James River and across the 


\section{THE UNITED STATES}

Blue Ridge Mountains. As time passed, the South Sea receded into the far-distant West, but no colony was willing to surrender any of the territory which could be claimed on the basis of its ancient charter; and so it happened that when independence was proclaimed in I776 many colonies still maintained extensive and conflicting claims to the territory beyond the mountains as far west as the Pacific Ocean. Fortunately, the small colonies refused to approve the Articles of Confederation until these claims were abandoned, which the large. colonies finally agreed to; and thus it happened that when independence was finally recognized in 1783 , the western limits of the thirteen states did not extend beyond the Alleghany Mountains, while the immense stretches of rich prairie and woodland from the Alleghanies to the Mississippi and from the Spanish province of Florida to the Great Lakes-an area of about four hundred thousand square miles-became the public domain of the federal government.

To most men of that age this immense hinterland seemed adequate for an indefinite future; the hope of adding anything to it would have been regarded as visionary in face of the immediate problem of defending it against Spanish or French or English aggression. But the extraordinary good fort146 


\section{AN EXPERIMENT IN DEMOCRACY}

une of the -United States began early and has lasted long. In 1803 President Jefferson sent James Monroe to France to assist Robert $R$. Livingston in inducing the French government to cede New Orleans and West Florida, in order that the United States might be assured of free navigation of the Mississippi. He had not much hope of succeeding in achieving even this modest cession, and Livingston's surprise can be imagined when, on the IIth of April, Napoleon's Minister, Talleyrand, suddenly offered to sell the entire province of Louisiana. A gift of this sort could not be refused; the sale was early concluded and the whole province of Louisiana was added to the territory of the United States. The territory thus added to the public domain 'comprised the whole west bank of the Mississippi (including those parts of it for many years claimed by Great Britain, but finally conceded to the United States), its western limits marked by a line beginning at the mouth of the Sabine River on the Gulf of Mexico, running irregularly north and west to the $42^{\circ}$ north latitude, and thence west to the Pacific. The extent of the cession was approximately $1,182,75^{2}$ square miles - an area of $756,96 \mathrm{r}, 280$ acres, acquired at a cost of a little less than four cents per acre.

Once possessed of the province of Louisiana, 


\section{THE UNITED STATES}

the desire to acquire possession of all the territory from sea to sea was bound to follow. This ambition, later described as the "Manifest Destiny" of the United States, was realized within the brief space of half a century. In 1819-21 East and West Florida-an area of 37,931,520 acres-was purchased from Spain at a cost of about seventeen cents per acre. In 1846 , as the result of a war of pure aggression, it must be confessed, the United States took from Mexico the territory comprised in the present states of California, Nevada, Utah, New Mexico, and western Colorado - an area of $334,443,520$ acres. From Texas, which, having won its independence from Mexico, became a state in the Union in 1837 , the federal government, in I 850 , purchased $61,892,480$ acres at a cost of twenty cents per acre; and in 1883 it purchased from Mexico, at a cost of thirty-four cents per acre, additional territory to the extent of $29,142,400$ acres. The entire public domain of the United States, excluding Alaska, was thus in excess of two million square miles, or about one and a quarter billion acres.

\section{III}

Never before had any nation so splendid a heritage for the people. What would the 148 


\section{AN EXPERIMENT IN DEMOCRACY}

government do with it? Would it hold the public domain in trust for the poor and the needy, or, yielding to political intrigue, barter it away to the land-jobber and allow the common man to take care of himself? In the course of a hundred years much politics has been played in connection with the public land, some men have made fortunes and some have lost them, there has been corruption, there has been an almost criminal waste of material resources-forests and mines - to the profit of great corporations. In a new country calling for hasty development, and with resources so unlimited, it could scarcely have been otherwise; but on the whole, the record of the government in disposing of the public land has not been a bad one.

It is partly to the credit of the government that America is, as yet at least, a nation of small freehold landowners. Even in colonial times the attempt to transplant the feudal system of land tenure to this country was scarcely successful. The founders of New England from the very first gave careful attention to the distribution of the land, which was granted first to the town corporations and by them allotted in small farms to heads of families. As the common ownership by the towns disappeared, the land passed to the settlers in freehold tenure. The town long 
retained certain "common lands"-meadow or woodland-of which there are survivals to this day, such as the famous Boston Common; but from the beginning New England avoided all forms of subject tenures, either in the form of perpetual rents paid to great landowners or in the form of "quit-rents" paid to the state.

The provinces outside of New England were not so fortunate. Most other colonies were originally founded by individual proprietors or commercial corporations who expected to exploit the land by forms of subject tenure familiar in the Old World. In Virginia, for example, after the dissolution of the Virginia Company in 1624, lands were granted only in return for perpetual "quit-rents" paid to the colonial government. In Pennsylvania "quit-rents" were paid to the proprietor. The same was true in Maryland and the Carolinas, whose original proprietors had splendid schemes for transplanting in America the feudal system of landholding, and the system of class distinction based upon it, with which they were familiar in England.

But all of these efforts ultimately failed. Land was so plentiful that settlers would not come, or would not stay, where the price was high or the conditions of tenure unfavorable. In the eighteenth century German immi- 


\section{AN EXPERIMENT IN DEMOCRACY}

grants occupied land in Pennsylvania as "squatters." Rather than pay the £Io or £I5 per 100 acres which the proprietor charged, they moved southward into Maryland where land sold for from $£_{2}$ to $£_{5}$ per I00 acres. Immigrants avoided New York because all the best land along the Hudson had been appropriated by wealthy landowners who refused to grant it out in freehold tenures. No system of perpetual rents could long endure in the New World where unlimited quantities of land were lying unused for the want of men to develop them. The last vestiges of the colonial system of subject tenantry, which had been most effectively established in New York in the great estates along the Hudson, were swept away as a result of the famous "Rent Riots" of 1846.

The federal government of the United States, in dealing with the public domain, never attempted to establish a system of subject tenures; but in the first period after winning independence it regarded the public lands somewhat in the light of a financial asset. The government was desperately poor, and it was hoped that by disposing of large tracts of Western land to wealthy men or to corporations it could obtain in a few years money enough to pay its debts. With this in view, the government of the Confederation 
sold, in October, I781, 5,000,000 acres in the Ohio country to the Ohio Company; and in May, 1788, 2,000,000 acres more were sold to John Cleves Symmes, and the price to be paid for all this land was approximately $662 / 3$ cents an acre. The land act of May 10, 1800, raised the price to $\$ 2$ per acre and permitted the sale of land to individuals in lots as small as 320 acres in some regions, and 640 acres in others.

During the next twenty years about twenty million acres of land were sold under the terms of this act. But the whole system of these early years was open to criticism. It was based upon the mistaken idea that the government could, or ought to, make money out of the sale of its land, and this idea led in turn to a method of sale which favored the wealthy, which opened the door to unscrupulous politicians and land-jobbers, and which, accordingly, discriminated against the actual settlers, who were required to buy more land than they needed at a higher price than they could afford to pay.

The early system was in fact gradually modified and ultimately abandoned altogether, and in the successive modifications the guiding principle was that the interests and the capacities of the actual settlers ought to be considered first of all, without reference 


\section{AN EXPERIMENT IN DEMOCRACY}

to the desires of speculators or the financial needs of the government. In 1820 the price was reduced to $\$ \mathbf{1} .25$ per acre, the minimum offered for sale was reduced to 80 acres, and in 1832 was again reduced to 40 acres. Meantime, in 1801 , a practice had been adopted which was greatly to the advantage of the actual settlers. It often happened that poor men, who were not able or not willing to pay the price asked, would take possession without legal right of unoccupied land which had not yet been offered for sale. When the land so occupied was finally sold, the actual settlerthe "squatter"-could be removed. But from about I80I it came to be the practice to give to the "squatter" the first right to buy the land which he had taken possession of, in preference to all others. This was the beginning of the so-called right of "pre-emption." What the rights of "pre-emption," as defined by various laws passed between I80I and I84I, amounted to was this: Any citizen might "pre-empt" the title to a certain amount of unoccupied land (40 acres was the minimum after 1832) by actual residence in a dwelling upon the land, and by cultivating a certain portion of it. If he fulfilled these conditions he was to have a certain number of years in which to complete the title by paying for the land, and during that term of 


\section{THE UNITED STATES}

years no one could evict him or acquire a title that would be valid against his.

This was a fairly liberal policy, for it permitted men without any ready money to get possession of farms without any formality whatever, and to pay for them afterward. But as time passed many people began to ask a very sensible question. Since the land belongs to the government, they said, and since the government belongs to the people, why should the people pay itself for its own land? And especially since there is so much land lying waste for the want of men to work it, and many poor people wanting nothing better than a chance to work it, why should a poor man be asked to pay anything for a small farm of 50 or 80 or 160 acres? This question became a national political issue in I 852, when the Free Soil party included the following statement in its declaration of principles:

That the Public Lands of the United States belong to the people, and should not be sold to individuals, nor granted to corporations, but should be held as a sacred trust for the benefit of the people, and should be granted in limited quantities, free of cost, to landless settlers.

After ten years of agitation this principle was finally embodied in what is known as the 


\section{AN EXPERIMENT IN DEMOCRACY}

"Homestead Law" of May 20, 1862. The essential terms of this law, which might well be called the poor man's charter of independence, deserve to be often recalled, and are well worth recording:

That any man who is the head of a family, or who has arrived at the age of twenty-one years, and is a citizen of the United States, or who shall have filed his declaration of intentions to become such ... shall ... be entitled to enter one-quarter section ( 160 acres) or a less quantity of unappropriated public land, upon which said person may have filed a preemption claim, or which may, at the time the application is made, be subject to pre-emption at $\$ \mathbf{1 . 2 5}$, or less, per acre. Provided, however, that no certificate shall be given or patent issued therefor until the expiration of five years from the date of such entry; and if, at the expiration of such time, or at any time within two years thereafter, the person making such entry (or his heirs) shall prove by two credible witnesses that he (or his heirs) has resided upon or cultivated the same for the term of five years immediately succeeding the time of filing the affidavit aforesaid, and shall make affidavit that no part of the said land has been alienated, and that he has borne true allegiance to the government of the United States; then, in that case, he (or his heirs) shall be entitled to a patent, as in other cases provided by law.

Under the terms of this law, entries were made, during the forty-two years immediately following its passage, for a total of $96,495,030$ acres of land. 


\section{THE UNITED STATES}

It has been estimated by Donaldson that the public domain acquired up to the year I 880 was about I, $849,072,587$ acres, of which the cost to the government, including the expense of surveys, administration, and sale, was about 18 cents an acre. Prior to June 30 , I880, something more than $500,000,000$ acres had been disposed of, in various ways, at an average price of about 36 cents an acre. According to the report of the Public Land Commission of 1905 , the government had, up to July 1, 1904, alienated by sale and gift a total of $967,667,449$ acres. Of this amount, 276,558,218 acres were sold for cash; $96,495,030$ acres were granted under the terms of the Homestead Act; I I 7,550,292 acres were granted to railroads; I I $4,502,528$ acres were classed as forest reserves; $69,058,443$ acres were granted to states and territories for school purposes; $65,739,264$ acres were granted as "swamp lands." What proportion of the alienated lands passed to poor men it is impossible to say, for under all the acts for the disposal of the public lands, even those, such as the Homestead Act, which were designed exclusively for bona fide farmers, the land-jobber has by fraud or otherwise found it possible to play his game. But at all events throughout the nineteenth century, especially after about 1820 and until about I890, it was 156 


\section{AN EXPERIMENT IN DEMOCRACY}

always possible for any man, however poor, to enter the class of landed proprietors.

The abundance of free land is the obvious explanation of the rapid increase in population in America, and hence of the swiftness with which the whole continent has been occupied and subdued to the uses of man. No such rapid increase in population had ever been known in Europe. The population of England in 1685 was about five million; in I80I it was about nine million; that is to say, the population of England had not doubled once in a hundred and sixteen years. But long before Malthus had formulated his famous law of population, which was based upon the assumption that under favorable conditions of subsistence population would increase in a geometrical progression, Benjamin Franklin had observed that this was precisely the case in America.

It was in $175 \mathrm{I}$ that Franklin published a pamphlet on the Increase of Mankind and the Peopling of Countries, in which he estimated that the population in the Colonies doubled every twenty years. And he predicted that this rate of increase would continue indefinitely, so that within another hundred years there 


\section{THE UNITED STATES}

would be more English-speaking people in North America than in old England. The fundamental explanation for this unprecedented phenomenon, as Franklin clearly saw, was the presence of unlimited quantities of land easily obtained.

Land being thus plenty in America, and so cheap as that a laboring man, that understands Husbandry, can in a short time save money enough to purchase a piece of new land sufficient for a plantation, whereon he may subsist a family, such are not afraid to marry; for, if they look far enough forward to consider how their children, when grown up, are to be provided for, they see that more land is to be had at rates equally easy, all circumstances considered.

Hence marriages in America are more general and more generally early than in Europe. And if it is reckoned there, that there is but one marriage per Annum among Ioo persons, perhaps we may here reckon 2; and if in Europe they have but 4 births to a marriage (many of their marriages being late), we may here reckon 8, of which, if one-half grow up, and our marriages are made, reckoning one with another at 20 years of age, our people must at least be doubled every 20 years.

But notwithstanding this increase, so vast is the territory of North America, that it will require many ages to settle it fully; and till it is fully settled, labor will never be cheap here, where no man continues long a laborer for others, but gets a plantation of his own; no man continues long a journeyman to a trade, but goes among those new settlers and sets up for himself, etc. 


\section{AN EXPERIMENT IN DEMOCRACY}

The conditions which Franklin described in the middle of the eighteenth century have continued to exist until very recently. And these are the conditions which therefore explain the unprecedented rapidity with which the people of the United States have transformed this immense wilderness into prosperous and civilized communities.

This expansive movement of the people westward has gone steadily on from colonial days; decade by decade, year by year, the frontier line of settlement, where the white man encountered the red man and savagery receded before a crude and primitive civilization, has crept like the edge of an incoming tide toward the Pacific. In the seventeenth century the frontier line was the Atlantic tidewater regions, and the frontiersmen of that age were the Puritans of New England, the Cavaliers and Redemptioners of Virginia, and the Dutch and Swedes and English Quakers of the Middle colonies. According to the census of 1790 the settled area was limited by the Alleghanies; but beyond the map was dotted by little communities in Kentucky and Tennessee, and on the upper Ohio River. By 1825 the frontier had been pushed forward to the Mississippi River, and the settled area included Ohio, southern Indiana and Illinois, Kentucky and Ten- 


\section{THE UNITED STATES}

nessee. Thirty years later the frontier was roughly the Missouri River, and settlers were pushing into eastern Kansas and Nebraska and northward into Wisconsin and Minnesota, while the discovery of gold in California had created a far-western frontier on the Pacific Coast. The census of I 880 revealed an irregular frontier line running in northern Wisconsin and Minnesota, with settlements along the rivers in Dakota, Nebraska, and Kansas, in Colorado and California.

The story of this steady advance across the continent is the great epic of American history - a New World crusade for the conquest of the wilderness. It is a story fascinating in its variety, richly colored by the romance of adventure and of hazardous enterprises, never lacking in masterly leaders, in eccentric characters, or bizarre incident-a story of human endeavor, of ends achieved by ruthless strength and harsh cruelties, by humane and generous actions, by heroic deeds and misfortunes nobly endured. But there is more in this story than a tale of adventure; rightly told, it will reveal the secret of American history - the persistence of democratic ideals which flourish in the simple and primitive conditions of a frontier society.

The influence upon the United States of this century of expansion westward, involving 


\section{AN EXPERIMENT IN DEMOCRACY}

in every generation a return to simple and primitive conditions of life, can be more easily understood if we try to imagine what would have happened if the Pacific had in fact, as the first settlers imagined, washed the western slopes of the Alleghanies. In that case, the United States, confined to the Atlantic coast regions, would no doubt have rapidly come to be a thickly populated country, with little free land, with a consequent rapid development of industrial and social conditions similar to those in European countries. Economic dependence upon Europe would have involved close political relations, and close political relations would have implied a similar if not an imitated culture. The United States never could have turned its back on the Old World, and its ideas and its ideals would have been borrowed from London and Paris.

This has, indeed, been true in some measure of the Atlantic coast states, and particularly of New England. To this day Bostonians have what Americans call an "English accent," and European travelers have always found Boston more English than any other part of America, just as they have always found the entire Atlantic coast region more European than the country west of the Alleghanies. It was the expansion of population into the Mississippi Valley that emancipated 


\section{THE UNITED STATES}

the United States from Europe. As the center of population moved westward the center of political power moved westward. New England and the Atlantic states lost their predominant influence, and the course of American history and the character of American society were more and more determined by the interests and the ideas of a frontier society. For a hundred years American history has witnessed the repetition, in each generation, of the same process; in each generation a return to frontier conditions in a new area, involving, within this area, the oft-repeated social evolution from the most primitive to the most advanced types of industrial society.

Many years ago Prof. Frederick J. Turner, himself a product of the Middle West, pointed out in a brilliant pamphlet the significance of the frontier on American history.

In the case of most nations the development has occurred in a limited area; and if the nation has expanded, it has met other growing peoples whom it has conquered. But in the case of the United States we have a different phenomenon. Limiting our attention to the Atlantic coast, we have the familiar phenomenon of the evolution of institutions in a limited area, such as the rise of representative government; the differentiation of simple colonial governments into complex organs; the progress of primitive industrial society, without division of labor, up to manufacturing civilization. But we have in addition to this a recur162 


\section{AN EXPERIMENT IN DEMOCRACY}

rence of the process of evolution in each Western area reached in the process of expansion. Thus American development has exhibited not merely advance along a single line, but a return to primitive conditions on a continually advancing frontier line, and a new development for that area. American social development has been continually beginning over again on the frontier. This perennial rebirth, this fluidity of American life, this expansion westward with its new opportunities, its continuous touch with the simplicity of primitive society, furnish the forces dominating American character.

But let us picture a little more in detail this "perennial rebirth," this continual renewal of the process of social evolution. Professor Turner himself quotes the following extract from Peck's New Guide to the West, which was published in 1837:

Generally, in all Western settlements, three classes, like the waves of the ocean, have rolled one after another. First comes the pioneer, who depends for the subsistence of his family chiefly upon the natural growth of vegetation, called the "range," and the proceeds of hunting. His implements of agriculture are rude, chiefly of his own make, and his efforts directed chiefly to a crop of corn and a "truck-patch." ... A log cabin, and, occasionally, a stable and a corn-crib, and a field of a dozen acres ... are enough for his occupancy. It is quite immaterial whether he ever becomes the owner of the soil. He is the occupant for the time being, pays no rent, and feels as independent as the "lord of the manor." With a horse, cow, and 


\section{THE UNITED STATES}

one or two breeders of swine, he strikes into the woods with his family, and becomes the founder of a new county, or perhaps state. He builds his cabin, gathers around him a few other families of similar tastes and habits, and occupies till the range is somewhat subdued, and hunting a little precarious, or, which is more frequently the case, till the neighbors crowd around, roads, bridges, and fields annoy him, and he lacks elbow room. The pre-emption law allows him to dispose of his cabin and corn-field to the next class of emigrants; and to employ his own figure, he "breaks for the high timber," "clears out for the new purchase," or migrates to Arkansas or Texas, to work the same process over.

The next class of emigrants purchase the land, add field to field, clear out the roads, throw rough bridges over the streams, put up hewn log houses with glass windows and brick or stone chimneys, occasionally plant orchards, build mills, school-houses, court-houses, etc., and exhibit the picture and forms of plain, frugal, civilized life.

Another wave rolls on. The men of capital and enterprise come. The settler is ready to sell out and take the advantage of the rise in property, push farther into the interior, and become, himself, a man of capital and enterprise in turn. The small village rises to a spacious town or city; substantial edifices of brick, extensive fields, orchards, gardens, colleges, and churches are seen. Broadcloths, silks, leghorns, crapes, and all the refinements, luxuries, elegancies, frivolities, and fashions are in vogue. Thus wave after wave is rolling westward; the real Eldorado is still farther on.

The writer has traveled much among the first class, the real pioneers. He has lived many years in connec- 


\section{AN EXPERIMENT IN DEMOCRACY}

tion with the second grade; and now the third wave is sweeping over large districts of Indiana, Illinois, and Missouri. Migration has become almost a habit in the West. Hundreds of men can be found, not over fifty years of age, who have settled for the fourth, fifth, or sixth time on a new spot. To sell out and remove only a few hundred miles makes up a portion of the variety of backwoods life and manners.

This description, allowing for regional differences in the physical character of the country, represents in a general way a process which has been going on for a hundred years throughout the greater part of the United States. It is this "perennial rebirth," this continual renewal of the process of social evolution, this continual mobility of the population, that has kept America from growing prematurely old. This it is which has broken sectional barriers and made impossible the establishment of rigid class distinctions, which has developed a composite American national character, which has enabled Americans to retain to so great a degree the simplicity of their original political institutions and in such full measure their faith in democracy.

"In 1789 the states were the creators of the federal government; in I86I the federal government was the creator of a large majority of the states." This concise statement reveals one very fundamental influence which 


\section{THE UNITED STATES}

Western expansion had upon the history of the United States. It did more than any other single thing to weaken the old sentiment of state sovereignty and to strengthen the sentiment of nationalism. The men who migrated from Virginia and Pennsylvania and Massachusetts into the upper Ohio Valley very rapidly lost touch with the states from which they had come. They perhaps retained for a time a certain kindly recollection of the old home, but the sense of loyalty to the state inevitably disappeared. On the other hand, they had bought their land from the federal government, they lived for some years in the "Territory of Ohio," a temporary government controlled by the Congress of the United States, and when the territory of Ohio was admitted as a state in the Union it was by act of the federal government. In a very real sense the state of Ohio was the creature of the federal government, and it was the same with all of the new states admitted to the Union after 1789.

The new Western states were not only the creatures of the federal government, they naturally turned to the federal government for aid in many things. One primary need of the Western country was better means of transportation. As soon as they had a surplus of food products they needed to have access 166 


\section{AN EXPERIMENT IN DEMOCRACY}

to the Eastern markets; and, therefore, the West demanded the construction of better roads, and of canals, and, later, of railroadsenterprises which could be carried through only by the aid of the federal government itself. Furthermore, the Western agricultural states required manufactured commodities, and the Eastern states, in order to meet this demand, and also because their less fertile lands could not compete successfully with the West, began to develop manufactures. In order to protect these "infant industries" against foreign competition, the Middle and New England states wanted a system of tariff duties laid on importation from abroad. Through a system of tariffs and a system of "Internal Improvements," the federal government exercised a powerful influence in developing the economic life of the country and thereby acquired a political power and prestige undreamed of by the framers of the Constitution.

The expansion of population into the Western country contributed also in a less obvious but more profound way to the development of a feeling of nationality. In the Western country sectional differences and jealousies tended to disappear through the mingling of people from different sections. The people who made the state of Ohio came chiefly from 


\section{THE UNITED STATES}

Massachusetts, Pennsylvania, and Virginia. These men and women, thrown together in the equalizing conditions of a primitive wilderness society, rapidly lost those characteristics that made them peculiar. It was soon found that Puritan or Quaker, German Mennonite or Virginia Episcopalians were all very human persons when it came to clearing the forest, planting corn, fighting the Indians, and preserving a decent amount of law and order. In this mingling of people from the older regions, local exclusiveness and suspicion necessarily gave way to a more national, even a more catholic attitude of mind-an effect greatly strengthened by the large influx of foreign immigrants after 1820 . When the mobility of population was always so great, the strange face, the odd speech, the curious custom of dress, and the unaccustomed religious faith ceased to be a matter of comment or concern. The term "outlandish" lost its significance, and the term "stranger," among primitive peoples identical with "enemy," became thoughout the West a common form of friendly salutation.

The Westerner was crude and uncultivated, ignorant of books, and lacking in the niceties and refinements of life; but his varied experience of men and places, his close contact with the hard realities of life, emancipated 


\section{AN EXPERIMENT IN DEMOCRACY}

him from the provincialism that thrives among men who live and die in the same village, or those whose habitual intercourse is with people of their own class. In spite of its primitive crudity, the flux and mobility of life in the West developed a certain restless energy, an inventive resourcefulness, a flexibility of mind, a certain humane tolerance, and a kind of genial acceptance of ill and good fortune which form the basis of that national character which is called America.

Professor Turner has described the intellectual qualities that were developed by the primitive life of the West in words that are well worth quoting:

From the conditions of frontier life came intellectual traits of profound importance. The works of travelers from colonial days onward describe certain common traits, and these traits have, while softening down, still persisted as survivals in the place of their origin, even when higher social organizations succeeded. The result is that to the frontier the American intellect owes its striking characteristics. That coarseness and strength combined with acuteness and inquisitiveness; that practical inventive turn of mind, quick to find expedients; that masterful grasp of material things, lacking in the artistic, but powerful to effect great ends; that restless, nervous energy; that dominant individualism, working for good and for evil; and withal that buoyancy and exuberance which comes with freedom-these are traits of the frontier, or traits called out elsewhere because of the existence of the frontier. 


\section{THE UNITED STATES}

No trait was more essential to success in the primitive frontier life of the West than individual initiative. The man who went West to grow up with the country discovered that the process was not a passive one. He had to pit his strength and his resourcefulness against the stubborn resistance and inertia of the uncleared forest or the untilled prairie. There was no paternal government to fall back upon, and no settled social custom to direct or to restrain him. At every step he must decide what to do and how to do it; and upon these decisions his success or failure in acquiring the bare necessities of life, and often in preserving life itself, depended. For a hundred years, life under frontier conditions has developed this trait of individual initiative until it has become ingrained in the character of the people.

In developing the spirit of individual initiative and self-confidence, the frontier gave to men a strong sense of individual liberty. Personal initiative implies freedom of action, and uncontrolled freedom easily passes over into unrestrained license. The frontiersman, freed from external restraint of government or social convention, found, nevertheless, that the harsh facts of nature required a conformity of their own. He decided for himself what to do, and how to do it; but if he decided wrong, star-. 


\section{AN EXPERIMENT IN DEMOCRACY}

vation or the tomahawk of the savage might end his liberty with his life. The frontiersman was free to do as he pleased-but he was held responsible for what it was that he pleased to do. In the harsh school of frontier experience only the fit could survive; and thus the strong sense of individual liberty which is so ingrained in American character is checked by an ever-present realization of the necessity of conforming to the realities of existence.

The long period of relatively simple frontier conditions has also preserved and strengthened the idea of equality. It was not that in the frontier of the first pioneers, or in the simple agricultural communities that were later established, all men appeared to be alike, or equal in power or virtue. On the contrary, in these communities the natural inequalities between men were thrown into strong relief. No man could avoid the merciless, if friendly, curiosity of his neighbors, or long pass for anything except what he was. Pretense was useless; birth or polite learning or social accomplishment counted for nothing. What counted was a man's resourcefulness, his success in doing what had to be done, and what every one was doing. And the able manas hunter or Indian-fighter, as farmer or woodman or mechanic, as composer of quarrels, or as leader of men-won whatever recognition 


\section{THE UNITED STATES}

his ability entitled him to. The idea of equality which the frontier developed was not an equality of rewards or of possessions; it was the idea of equality of opportunity and of reward according to merit.

The disposition to take a man for what he is, without regard to his rank or title, a trait which American national character owes so largely to frontier conditions, has been noted by James Bryce in his great book, The American Commonwealth. The second charm of American life, he says-

is one which some Europeans will smile at. It is social equality. To many Europeans the word has an odious sound. It suggests a dirty fellow in a blouse elbowing his betters in a crowd, or an ill-conditioned villager shaking his fist at the parson and the squire; or, at any rate, it suggests obtrusiveness and bad manners. The exact contrary is the truth. Equality improves manners, for it strengthens the basis of all good manners, respect for other men and women simply as men and women, irrespective of their station in life. Social equality has grown so naturally out of the circumstances of the country, has been so long established and is so ungrudgingly admitted, that all excuse for obtrusiveness has disappeared. People meet on a simple and natural footing, with more frankness and ease than is possible in countries where every one is either looking up or looking down. There is no servility on the part of the humbler, no condescension on the part of the more highly placed, nor is there even that sort of scrupulously polite coldness which one might think they 


\section{AN EXPERIMENT IN DEMOCRACY}

would adopt in order to preserve their dignity. They have no cause to fear for their dignity, so long as they do not themselves forget it. And the fact that your shoemaker or your factory hand addresses his employer as an equal does not prevent him from showing all the respect to which any one may be entitled on the score of birth or education or eminence in any walk of life.

Together with this sense of equality between men, the frontier also developed, often underneath a harsh exterior, a humane and kindly fellow-feeling, which Mr. Bryce has noted as a distinguishing American trait:

I come last to the character and ways of the Americans themselves in which there is a certain charm, hard to convey by description, but felt almost as soon as one sets foot on their shore, and felt constancly thereafter. In purely business relations there is hardness, as there is the world over. Inefficiency has a very short shrift. But apart from these relations they are a kindly people. Good nature, heartiness, a readiness to render small services to one another, an assumption that neighbors in the country, or persons thrown together in travel, or even in a crowd, were meant to be friendly rather than hostile to one another, seem to be everywhere in the air and in those who breathe it. Sociability is the rule, isolation and moroseness the rare exception. $\overrightarrow{\mathrm{I} t}$ is not that people are more vivacious or talkative than an Englishman expects to find them, for the Western man is often taciturn and seldom wreathes his long face into a smile. It is rather that you feel that the man next you, whether silent or talka- 


\section{THE UNITED STATES}

tive, does not mean to repel intercourse, or convey by his manners his low opinion of his fellow-creatures. Everybody seems disposed to think well of the world and its inhabitants, well enough at least to wish to be on easy terms with them and serve them in those little things whose trouble to the doer is small in proportion to the pleasure they give to the receiver. To help others is better recognized as a duty than in Europe. Nowhere is money so readily given for any public purpose. ... People seem to take their own troubles more lightly than they do in Europe, and to be more indulgent to the faults by which troubles are caused. It is a land of hope, and a land of hope is a land of good humor.

America is, as Mr. Bryce says, "a land of hope"; and that it is so has been largely due to the boundless possibilities of the great West. The unlimited resources of the country, and the incredible rapidity with which they have been developed, have combined to give to the American character a strain of buoyant optimism. To the American sense of liberty and of equality must be added a marked spirit of idealism. Americans have often been classified as crudely materialistic - "dollarchasers" whose one idea is to seek wealth and pursue it. Certainly it is true that our main occupation is "business," our great art the art of making money. But this means only that the primary task of America has hitherto been the development of the physical and 


\section{AN EXPERIMENT IN DEMOCRACY}

material resources of a virgin country. Americans have been primarily occupied with material things; but they have conceived of this task in a highly idealistic spirit. The American makes money easily, but he spends it carelessly, lavishly. It is not money, but the making of money, the enterprise, the game, the adventure of big business, that enlist his enthusiasm. America is a big country, and the subjection of this vast continent within the short space of a hundred years has accustomed the American to think in terms of quantity - the tallest building, the biggest city, the longest railroad-these things strike the imagination because they measure achievement.

There is in the state of New York a little town of about twenty thousand inhabitants, located in the foothills of the Alleghany Mountains at the head of Lake Cayuga. It is the seat of the university with a deservedly high reputation, the library of which contains what is said to be the finest Dante collection in the world, and an admirable collection of books and pamphlets on the French Revolution-probably the best in America. The town of Ithaca is in many ways charming and delightful and attractive above most towns in the country. Now, the business men of this town have a motto which they have 


\section{THE UNITED STATES}

doubtless designed to convey to the world the thing which is distinctive of the town, and most worthy of note about it. And what is it that they found distinctive of this town, which is so notable for the beauty of its surroundings and for the quality of its intellectual activities? On all of the fences and sign-posts for miles around, they have put up this sign"Ithaca, the Biggest Little City!"

In this motto the business men of Ithaca have tried to convey not a reality, but an ideal. Ithaca can never in reality be a big cityit can never rival New York or Chicago. But the thing that strikes the American imagination about a city like New York or Chicago is the ceaseless enterprise, the farsighted intelligence, the adventurous daring of the men who have made them the great centers of economic life; and the men of Ithaca wish you to understand that if their town is not so great as Chicago, it is due to the disadvantages of its location and not to any want of vision or of enterprise on the part of its inhabitants.

The United States is full of these "biggest little cities." And this is particularly true in the West, where there are many cities of three or four hundred thousand inhabitants that were founded within the memory of living man. You meet these energetic business 


\section{AN EXPERIMENT IN DEMOCRACY}

men who were perhaps born in Illinois, educated at the University of Michigan, and have "located" in Kansas or Utah (you meet them in the smoking-room of the Pullman cars traveling to New York, Heaven knows why!), and they will tell you of the town in which they live. It is always the "finest town in the state," although you have never before heard of it, and you judge by the account that it is exactly like a hundred other dreary Western towns. But sooner or later you learn the secret of the man's enthusiasm when he says, "It's going to be a great country some day!" Such are Americans, hurrying on with restless energy, with tense, set faces, and eyes fixed upon that future idealized state of "some day."

It was this type of idealism which clearly inspired the writer of an editorial which was published in a newspaper at New Tacoma many years ago. The editorial was entitled, "Why We Should Be Happy." It appeared that the people of New Tacoma should be happy:

Because we are practically at the head of navigation on Puget Sound. Tacoma is the place where all the surplus products of the South and the East, that are exported by way of the Sound, must be laden on board the vessels that are to carry them to the four corners of the world. We should be happy because, being at the head 


\section{THE UNITED STATES}

of navigation on Puget Sound, we are also nearer by many miles than any other town on Puget Sound to that pass in the Cascade Mountains through which the Cascade division of the Northern Pacific Railroad will be built in the near future. ... We should be happy ... because we are connected by rail with Portland ... with St. Paul, Chicago, and New York; because being thus connected we are in daily communication with the social, political, and financial centers of the Western Hemisphere; because all the people of the South and of the East who visit these shores must first visit New Tacoma. ... We should be and we are happy because New Tacoma is the Pacific coast terminus of a transcontinental line of railroad-because this is the only place on the whole Pacific coast north of San Francisco where through freight from New York can be loaded on ship directly from the cars in which it came from the Atlantic side.

Other reasons why we should be happy are that New Tacoma is in the center of a country where fruits and flowers, vegetables and grain, grow in almost endless variety; that we are surrounded with everything beautiful in nature ... and that there are opportunities here for the fullest development of talents of every kind. We have youth, good health, and opportunity. What more could be asked?

This vision of bliss would certainly make no great appeal to a people who were in fact given over to material enjoyments.

Frontier conditions have thus developed in America a high degree of individual initiative, a strong sense of individual liberty in respect to certain things, and a marked tendency to 178 


\section{AN EXPERIMENT IN DEMOCRACY}

estimate material conditions in terms of their future possibilities. These admirable qualities have, however, their defects. It is a tradition with us that we are a tolerant people. Were we not the first to establish complete religious toleration? And have we not always maintained it? Surely. But the truth is that we are tolerant mainly in respect to matters which we regard as indifferent. We tolerate religions, but look askance at irreligion. We tolerate political opinions, but are afraid of anti-political opinions. The average American, when confronted with any conduct or expression of opinion which he regards as "dangerous," or as "morally wrong," instinctively wishes to "do something about it." We have been so long occupied with practical problems of the material order, have been so completely absorbed in action, that ideas, as such, ideas divorced from immediate practical ends, seem to us permissible mainly as a diversion, and so long as they can be dismissed lightly as "interesting" or "amusing." In all serious matters-matters not to be àpproached in the spirit of the amateur-we prefer ideas cast in formal mold, are at a loss in the midst of flexible play of mind, and look with suspicion on the emancipated, the critical, the speculative spirit. All that is academic, to be confined to the schools, and to be 


\section{THE UNITED STATES}

put off when we pass out of the schools into "real life." In real life the average American, knowing that he is right, wishes only to go ahead; satisfied with certain conventional premises-obscure premises embodied in certain great resounding words such as liberty, democracy, equality, toleration-he hastens on to the obvious conclusion. When the newspapers affirm, as they are fond of doing, "we are a tolerant people," the context is likely to show that what the writer really means is that we are a patient, easy-going, good-natured people; and the phrase itself is usually the prelude to the downright assertion that in respect to something or other-profiteering, or bolshevism, or Sunday baseball-our patience is almost exhausted. We are tolerant of the thing or idea until the thing or idea becomes intolerable. We are tolerant - that is to say, we are good-natured and can take a joke-but don't count on carrying the funny business too far. That every one should do as he likes, or think as he likes, is part of the American creed only to a limited extent. That it is possible to know what is "right," and that what is right should be recognized and adhered to, is the more fundamental faith.

This habitual dislike of thinking, this aversion for ideas, apart from the type of thinking 


\section{AN EXPERIMENT IN DEMOCRACY}

and the order of ideas required for dealing with concrete practical problems, is closely connected with that talent for "organization" which is so characteristic of Americans. If anything is "to be done," an "organization" - a committee, a society, a club, a corporation, an association-is built up overnight, marvelously adapted to the "doing" of anything that can be done by routine mechanical methods. Every one readily "falls into line" and does his bit. But this facility implies on the part of individuals a disposition to do something rather than to think something; and indeed the great service of our endless "organizations" is that they conveniently relieve us all of the trouble of thinking for ourselves.

"What do you think about the tariff?"

"Oh, I am a Republican; I never scratch the ticket."

He does not have to think about the tariff; the party decides that, and, like Rousseau's citizen, he has entered into a tacit contract by which he subordinates the individual to the general will.

"What do you think about the wisdom of these Liberty loans?"

"Well, I don't know; but we've got our quota, and we've got to put Tompkins County over the top." 


\section{THE UNITED STATES}

He does not have to decide whether Liberty loans are a good thing or a bad thing; he has to put Tompkins County over the top; he has to show those Syracuse fellows that Tompkins County can do whatever is put up to it to do. "What are your religious views?" "Well, you know I am a Methodist."

What he means is that he doesn't have to think about religion; the Methodist Church attends to that, and no one can say a word against the Methodist Church. Americans have a passion for regulating whatever is regarded as important; they like to place their opinions in the safety-deposit box of some organization. In respect to all harmless eccentricities they are easy-going and good-natured enough - "Oh well, I guess it don't make any difference!"

These qualities - good nature, individual initiative, idealism, aversion from speculative thinking, an intolerance toward "wrong" conduct and "bad" ideas which under excitement is likely to run to frenzy and fanaticism-all these characteristic American qualities, as they have been fostered by two centuries of provincial frontier conditions, are still more strongly manifested in the newer Western than in the older Eastern communities. Up to the moment when the United States entered the war the West was regarded as "pacifist." 


\section{AN EXPERIMENT IN DEMOCRACY}

People generally were indifferent to the war. It was a remote, European affair, with which they had nothing "to do." But when the United States entered the war, then they had something to do, and they proceeded with characteristic energy to do it. Mr. Wilson told them that the United States had to go in. "Very well," they said, "since we have to go in, we must do a good job of it; we must put the business over." Once organized for the war, the enthusiasm of the West rose to the highest possible pitch, and no opposition to the war could be tolerated-neither opposition to the war nor criticism of the government in the defense of which "the boys" had put on the uniform and for the sake of which some of them lay dead in France; so that it was reserved for an Iowa judge to affirm as his solemn conviction that American history and institutions should never, in the schools, be brought into comparison with European history and institutions except in so far as the former could be shown to be superior to the latter. The Iowa judge would doubtless have justified his position by saying that it is wrong to discredit American institutions because it is wrong to undermine the great principle of liberty and equality upon which American institutions are founded. 


\section{THE UNITED STATES}

$\mathbf{v}$

In 1890 the superintendent of the census made the following significant statement:

Up to and including 1880 the country had a frontier of settlement, but at present the unsettled area has been so broken into isolated bodies of settlement that there can hardly be said to be a frontier line. In the discussion of its extent, its westward movement, etc., it cannot, therefore, any longer have a place in the census reports.

This brief official statement, as Professor Turner well says, "marks the closing of a great historic movement." In our day the era of unlimited free land suitable for cultivation has already passed, and with the disappearance of free land, the old freedom for the individual, the old equality of opportunity, which have hitherto been the guaranties of American democracy, are things of which one can no longer speak with the same confidence. The abnormal price of the best farm land, which now, in the states of Iowa and Illinois, sells for from $\$ 250$ to $\$ 425$ per acre, is slowly but surely creating a permanent class of tenant farmers, while the abnormal concentration of industrial power is not only creating a permanent class of wage-earners, but is placing the control of the production and the distriI 84 


\section{AN EXPERIMENT IN DEMOCRACY}

bution of wealth in the hands of the few. Political democracy we have; but the old economic democracy is rapidly becoming a thing of the past. To achieve, under these changed conditions and by new methods, the economic freedom without which political freedom is of little use is the task of the coming years. 


\section{VII}

DEMOCRACY AND SLAVERY

WHEN Jefferson wrote the Declaration of Independence, proclaiming as a universal truth that "all men are created equal," negro slavery was a legalized institution throughout the thirteen states. The contrast between the actual fact and the proclaimed truth was flagrant and irreconcilable. Jefferson and his associates were entirely aware of the fact. It was commonly believed at the time that slavery was a moral as well as an economic evil, but the leading men of the day looked forward to the early disappearance of the evil. Jefferson and Washington and many others, although themselves the owners of slaves, were sincerely interested in the movement for gradual emancipation; and they hoped and expected that the institution would not outlast the century of which the dominant spirit was a passionate concern for human freedom. They would have been I 86 


\section{AN EXPERIMENT IN DEMOCRACY}

amazed and disheartened could they have known that within fifty years negro slavery would be the foundation of the economic and social life of the Southern States, that it would threaten the very existence of the federal Union, compromise the future of free government, and end at last in a desperate and sanguinary civil war.

The rapid and unforeseen development of slavery in the South was due to one of those slight changes in the mechanics of industry which so often exercise a profound influence upon the course of history. In 1793 Eli Whitney invented the cotton-gin, a simple device for separating the seed from the fiber which, by enabling one man to do the work of three hundred, so greatly increased the profit of cotton culture that cotton soon became one of the chief of American products. For the raising of cotton, negro slaves were thought to be peculiarly suited; and wherever cotton could be raised negro slavery became every year more intrenched, was every year more complacently excused by its beneficiaries as an economic necessity, and at last defended as a social and moral blessing. But cotton could be raised only in the South. It was, therefore, only in the South, where slaves were profitable, that slavery increased and was defended, while in the North, where 


\section{THE UNITED STATES}

slaves were unprofitable, slavery disappeared and was denounced as an evil.

By I820 far-sighted men could see that slavery, whether right or wrong, would prove a serious problem because it threatened to divide the Union into two parts-North and South-with very different economic interests and institutions and with antagonistic moral and social ideas. As these differences became more pronounced, the divergence would perhaps create two nations instead of one, and in that case each group or nation would think that its own interests could not be adequately guaranteed unless it had at least an equal power in the common federal government. And in fact for many years it was the tacit understanding that the equal influence of the two sections should be preserved in that branch of the federal government - the Senate -in which every state had the same number of representatives.

It happened that the division between slave and free states was sufficiently even, so that for some years the balance could be deliberately preserved by the admission of an equal number of free and slave states from the Western territories. So long as slavery was not regarded too seriously little friction arose in carrying out this policy. But in 1820 , in connection with the admission of the state of I 88 


\section{AN EXPERIMENT IN DEMOCRACY}

Missouri, it was proposed that throughout the whole of the territory west of the Mississippi (the Louisiana territory acquired in 1803 from France) slavery should forever be prohibited north of the line of $36^{\circ} 30^{\prime}$ north latitude. This would have excluded slavery from the proposed new state of Missouri, and as the Northern free state of Illinois had been admitted in 1819 , and the Northern territory of Maine was petitioning for admission, this would make three new free states without any

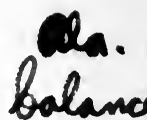
new slave state, and so give to the North a great advantage in the federal Senate. The question aroused wide-spread discussion, and was at last settled by the "Missouri Compromise," which established the dividing line at $36^{\circ} 30^{\prime}$, but provided that Missouri should be allowed to come in as a slave state. The "Missouri Compromise" was accepted as a permanent settlement, and for some years the slavery question was in abeyance. But the aged Jefferson, noting the sudden flaring up of angry controversy, likened the episode to a "fire-bell in the night." It was indeed the first clear warning of the coming danger.

The economic dilemma which negro slavery created was the same as that which is created 


\section{THE UNITED STATES}

by any system of slavery, including wageslavery-it was profitable to the individual slave-owner, but disastrous to the community. Hence the ruling class in the South, a relatively small part of the population, held on desperately to the institution which with every decade became a heavier handicap upon the Southern States in the competition with the North for economic and political power. It was primarily due to slavery that the South remained an agricultural community. Slaves were unsuited to manufactures. Cotton plantations and slaves, constantly increasing in value, absorbed Southern capital, and as manual labor was a disgrace where slavery existed, the poor whites preferred to vegetate on their small farms rather than work for wages, while the steady stream of foreign immigration flowed almost wholly into the North. Both in wealth and in population the free states, therefore, rapidly outstripped the slave states, and such wealth as existed in the South was largely confined to the relatively small class of great planters and slave-owners.

These economic disadvantages were increased by the steady rise in the price of slaves, due in part to the prohibition, after 1808 , of the foreign slave trade. Since the price of cotton did not advance in proportion, the continued profit of cotton-raising depended 190 


\section{AN EXPERIMENT IN DEMOCRACY}

upon cheap land and large-scale production. Cheap land was to be had in the Western territories, but in this respect the South was at a singular disadvantage also, for the division of the Western territory by the "Missouri Compromise" gave to the North the greater part of the Louisiana Purchase, while the population and wealth of the North enabled it to settle and exploit its share much more rapidly than the South could hope to exploit its share. By 1850 it was clear that if slavery were confined to the region south of $36^{\circ} 30^{\prime}$, the North, which already overbalanced the South in the federal House of Representatives, must eventually gain a great ascendancy in the Senate also.

This prospect would not have given the South so great concern if it could have been assured that the North would never use its political advantage to discriminate against Southern interests. The South came, therefore, to regard the union with the North as tolerable on the condition that the "peculiar institution," as it was called, should not be molested where it already existed. From the legal and constitutional point of view, the position of the South was a strong one, for the Constitution conferred upon the federal government no power of interfering with slavery in the states, and it was possible to 


\section{THE UNITED STATES}

argue that it had exceeded its powers in prohibiting it in the territories north of $36^{\circ} 30^{\prime}$. But in spite of legal protection, the South felt that with every decade the safety of the "peculiar institution" was becoming more precarious. This was indeed true. It was true because thè slavery question was not one which could be settled by compromise or confined within the limits of legal categories. Slavery was a moral question as well as an economic and constitutional one. It was the moral issue that came to enforce the economic differences between the sections and ultimately made these differences irreconcilable by any half-way measures. As an economic institution the slavery question might have been settled by compromise; as a moral question it could not be settled until the Union was destroyed or until it became all slave or all free.

From the eighteenth century slavery had been regarded as a moral evil by many people; and there had always been societies, animated by amiable humanitarian impulses, devoted to a mild sort of emancipation propaganda. But in 1831, when William Lloyd Garrison established the Liberator in Boston, the opposition to slavery was taken up by a different sort of men and in a radically different spirit. Previously, the South had had little to fear 


\section{AN EXPERIMENT IN DEMOCRACY}

from the prevailing Northern sentiment that slavery was in itself an evil, but that in the South, and under present conditions, it was probably a necessary evil for which the slaveowners were not to be held morally responsible, and which they must be left to deal with as time and circumstances might determine. Garrison and the "Abolitionists" altogether repudiated such views.

I shall strenuously contend [Garrison said] for the immediate emancipation of our slave population. I will be as harsh as truth and as uncompromising as justice. . . I I am in earnest-I will not equivocateI will not excuse-I will not retract a single inch-and I will be heard. ... I take it for granted slavery is a crime-a damning crime; therefore, my efforts shall be directed to the exposure of those who practise it.

Two points are significant in the above quotation. Garrison insisted upon the immediate emancipation of the slaves. If any one objected that the Constitution-the beloved Constitution-stood in the way of any such program, he could only reply that if the Constitution sanctioned slavery, then the Constitution was "a league with death and a covenant with hell." The second point is still more important. Garrison proclaimed slavery to be no "necessary evil," but a "damning crime," and he regarded all slave-owners as 


\section{THE UNITED STATES}

guilty of that crime, and, therefore, as vile and despicable men. This was the spirit of the new Abolition movement which William Lloyd Garrison began. It was an uncompromising attack upon slavery as a crime and upon slave-owners as criminals. The infamy must be abolished, the Abolitionists said; it must be abolished now; and in the way of this righteous object no consideration of personal feelings, of convenience, of vested rights, or of legal technicalities must be allowed to stand for a moment. For many years, throughout the North, the Abolitionists were despised as fanatics and feared as dangerous incendiaries. But the spirit which they aroused would not down; their following steadily increased; and even outside of their ranks they won, more and more, the sympathy of men who agreed with Emerson that although "they might be wrong-headed, they were wrongheaded in the right direction."

If the Abolitionists were despised and mobbed in the North, they were hated with a desperate hatred in the South. To say that slavery was a necessary evil was no reflection upon Southern planters. They had commonly, before I830, said as much themselves. Many things in this world are necessary evils and are complacently accepted as such. It could be said, and was said, that the wretched con- 


\section{AN EXPERIMENT IN DEMOCRACY}

dition of factory laborers in New England and old England cotton-mills was a necessary evil. But it was a different matter when people began to denounce slavery as an unnecessary evil, as a crime against humanity. Slave-owners might think the charge absurd, and as long as Abolition sentiment was confined to a few fanatics they could ignore it with contempt. But the danger was that Abolitionists might spread throughout the North, and if that came to pass, as it every day was coming to pass, the slave-owners knew well that it would be impossible to continue to live in political union with a people who regarded them as unworthy of a decent man's respect.

When slavery was challenged as a crime, the slave-owners could therefore no longer be content to describe it as a "necessary evil." The Abolitionist argument could be adequately met only by proving that slavery was a positive good, an institution that harmonized with the nature of things, a social arrangement which was a blessing to society and a benefit to the slave. Between 1830 and 1860 serious and humane and gifted men formulated such a defense of slavery. They were only following a marked trend of thought throughout the world when they maintained that the phrases of the Declaration of Independence were no 


\section{THE UNITED STATES}

more than "glittering generalities." The truth is, said Chancellor Harper, not that "all men are created equal," but rather that "man is born to subjection." A careful and unprejudiced study of history, he said, would reveal the fact that-

The exclusive owners of property ever have been, ever will, and perhaps ever ought to be the virtual rulers of mankind. ... It is the order of nature and of God that the being of superior faculties and knowledge, and therefore of superior power, should control and dispose of those who are inferior. It is as much the order of nature that men should enslave each other as that animals should prey upon each other.

This was written in 1837 , and at that date it was easy to point out, with much semblance of truth, that the industrial civilization of New England and of old England, no less than the agricultural civilization of the South, was based upon the subjection of the many by the few. There was a wage-slavery as well as a chattel slavery, and the South maintained that the former was worse than the latter. In I845 James H. Hammond published a series of letters in which he drew a heartrending picture of the condition of laborers in the great industrial centers. Since subjection was thus the essential basis of civilized society, that system was best where the master was re196 


\section{AN EXPERIMENT IN DEMOCRACY}

sponsible for the slave. Instead, therefore, of abolishing negro slavery in the South, this system should be taken as the model for the reform of industrial conditions in the North. The capitalists, according to Mr. Hammond, should become the owners of their laborers and as such be compelled to clothe and feed them decently; while in the West the public lands should be parceled out in great estates and tilled by the landless poor bound in perpetuity to the soil. ${ }^{1}$

As this philosophy came to be the accepted social and political faith throughout the South, its advocates ceased to be content with the negative policy of preserving slavery where it already existed. For Southern extremists, no less than for Northern extremists, the slavery question became a moral issue, capable only of a logical and a radical solution. If slavery was a damnable crime, as the Abolitionists said, then it ought to be immediately abolished everywhere - this the defenders of slavery admitted; but if it was, on the contrary, a positive social blessing, then it ought to be permitted everywhere-and this the advocates of slavery demanded. They demanded the repeal of the "Missouri Compromise" and the free access of slavery to all the territories;

${ }^{1}$ W. E. Dodd, Social Philosophy of the Old South, American Journal of Sociology, xxiii, p. 735 . 


\section{THE UNITED STATES}

they demanded the forcible suppression of the Abolitionists and of all Abolition literature; they demanded the active assistance of all Northerners in the return of fugitive slaves; they demanded that all criticism of slavery should cease and that it should be accepted not only as a legally established, but as a morally justifiable institution.

Put in this form, the challenge was accepted. Abolitionist sentiment spread rapidly in the North during the decade from I850 to I860; and nineteen years after a mob had dragged William Lloyd Garrison through the streets of Boston it required over a thousand armed soldiers supplied with a cannon loaded with grape-shot to take the fugitive slave Burns out of that town and send him back to Virginia. The prevailing sentiment was never Abolitionist. To the end the great majority of the people were opposed to any interference with slavery where it existed; but they looked with complacence upon the systematic violation of the fugitive-slave law, and set themselves more and more resolutely to resist the legal extension of the institution in the belief that if the evil were confined to the states where it already existed it would ultimately disappear altogether.

It was with this program in view that the Republican party was formed, and as the ex198 


\section{AN EXPERIMENT IN DEMOCRACY}

ponent of these views Abraham Lincoln became the leader of that party. In 1858 Lincoln touched the heart of the matter in the following lucid statement:

If we could first know where we are and whither we are tending, we could better judge what to do and how to do it. We are now far into the fifth year since a policy was instituted with the avowed object, and confident promise, of putting an end to slavery agitation. Under the operation of that policy, that agitation has not only not ceased, but has constantly augmented. In my opinion, it will not cease until a crisis shall have been reached and passed. "A house divided against itself cannot stand." I believe this government cannot endure permanently half slave and half free. I do not expect the Union to be dissolved-I do not expect the house to fall-but I do expect it will cease to be divided. It will become all one thing or all the other. Either the opponents of slavery will arrest the further spread of it, and place it where the public mind shall rest in the belief that it is in the course of ultimate extinction; or its advocates will push it forward till it shall become alike lawful in all the states, old as well as new-North as well as South.

At that time most of Lincoln's friends told him that this was an unwise thing to say"a fool utterance," one of them called it. But it was, in truth, the profoundest wisdom. The more the moderates in both sections agreed that the slavery question should be ignored the more it was discussed; and the 14 
more it was discussed the more irreconcilable the position of the two sections was seen to be. The moderate Whig party, both North and South, dwindled to a small minority, and when Lincoln was finally elected President, in 1860 , the Southern States seceed from the Union.

The meaning of the election was clear. It meant, says James Ford Rhodes, that-

The great and powerful North declared slavery an evil, and maintained that it should not be extended; that while the institution would be sacredly respected where it existed, the conduct of the national government must revert to the policy of the fathers and confine slavery within bounds, hoping that if it were restricted the time might come when the Southern people would themselves acknowledge that they were out of tune with the enlightened world and take steps gradually to abolish the system.

The Southern States seceded because the election of Lincoln demonstrated that Northern sentiment condemned slavery, and in condemning slavery it had placed a stigma upon the Southern people. To admit that slavery must not be extended was to admit that it ought not to exist. If the Southern people remained in the Union, they must either abolish slavery or be content with the position of a morally discredited minority whose social customs were temporarily tolerated for the sake of peace. They refused to do either. For the sake of slavery, and justify- 


\section{AN EXPERIMENT IN DEMOCRACY}

ing their action on the ground that any state had a constitutional right to withdraw from the federal Union, they fought a desperate war for independence and the right of selfdetermination.

\section{III}

In respect to the problem of secession, there was no consolidated public sentiment in the North. Many Democrats sympathized with the South and admitted the constitutional right of the states to withdraw from the Union; many humanitarian Abolitionists and some Republicans felt that if the Southern States were dissatisfied and wished to form a separate government, it would be the part of wisdom and humanity to allow them to depart in peace. While the great majority of the people were opposed to slavery, only a small minority were ready to take up arms for the avowed purpose of abolishing it. President Lincoln himself took the ground that the federal government would do nothing to interfere with slavery in the Southern States; but he said that no state had a legal right to secede; that those people in any state who attempted to do so were in a state of rebellion; and that the whole power of the federal government would be devoted to suppressing any resistance to the federal authority. It was on this 


\section{THE UNITED STATES}

ground that Northern sentiment came gradually to the support of the President. The North fought the Civil War, not for the suppression of slavery, but for the "preservation of the Union."

The right of any government to suppress insurrection or rebellion is generally admitted. But this was an exceptional case. The legal right of secession was open to discussion, but technically the South had a more logical and convincing argument in favor of the right than the North had against it. A movement which embraced ten million people, all inhabiting a particular and economically distinct section of the country, could scarcely be called an insurrection; and, in view of the radical differences in social customs and ideals, it might well be maintained that the natural development of the country had in fact resulted in the creation of two nations instead of one. Many people in Europe took this view. In I862 William E. Gladstone, at that time a member of the British government, declared in a public address that the "leaders of the South have made an army; they are making, it appears, a navy; and they have made, what is more than either, they have made a nation." On the ground that the South was a nation, that as such it had a right to self-determination, the British government 


\section{AN EXPERIMENT IN DEMOCRACY}

was on the point of recognizing its indepenence. By what right did the North use its superior power to compel the Southern people to submit to a government which they repudiated, and ultimately to abolish an institution to which they were devoted?

The subjugation of the Southern people must be justified, if at all, on two grounds. It was profound political wisdom, as well as good political tactics, in President Lincoln to have based the issue on the preservation of the Union. Free government as it existed in the United States was a new thing in the world $\rightarrow$ a kind of political experiment as yet not thoroughly tested, upon which the Old World looked with interest, but with doubt as to the outcome. Free governments had existed and still existed in the Old World; but the experience of the Old World, confirmed by the political philosophy of the eighteenth century, declared that free government, in any radical sense of the term, was suited only to small states, such as the city-states of Greece and Italy, or the cantons of the Swiss mountains. It was still a debatable question whether government by the people was suitable to an extensive territory; and in the experiment now being conducted in the United States no point was of greater interest or importance than this: Could a first-rate political power 


\section{THE UNITED STATES}

be erected and maintained on a democratic basis?

It is not too much to say that the disruption of the United States would have answered this question in the negative for a long future. Precisely this result had often been predicted by those who sought to discredit republican institutions and feared by those who supported them. It was said that a great continent like the United States must inevitably fall apart if it continued to be governed by public opinion. Sectional differences of interests and ideals must inevitably develop to the point where political union could be preserved only by a government which in some measure transcended public opinion, and in some degree rested upon military power. The divergence between North and South had now reached this point, and the contest between them would be decisive. If the South had won its independence, the result would have been to create an irresistible precedent, an unanswerable justification for any other section that was so minded to withdraw and go its own way. If the South had won, it is entirely conceivable, and indeed likely, that the United States would have rapidly dissolved into a congeries of petty republics contending among themselves for a New World balance of power, exhausting their resources in mili204 


\section{AN EXPERIMENT IN DEMOCRACY}

tary rivalry, surrendering half their freedom to some European alliance from fear of aggression or in the hope of ascendancy.

Such a result would have tremendously compromised the future of democracy. In Europe, above all in England, the disruption of the Union would have been taken to mean that no great state could hope to win or to retain pre-eminence in the world's affairs if it surrendered itself unreservedly to government by the people. This is precisely why the laboring classes in England supported the North, while the governing classes hoped for the success of the South. In 1863 John Bright stated, in words that the laborers of England could understand, the significance for them of the Civil War:

Privilege thinks it has a great interest in the American contest, and every morning, with blatant voice, it comes into our streets and curses the American Republic. Privilege has beheld an afflicting spectacle for many years past. It has beheld thirty millions of men happy and prosperous, without emperors-without kings [cheers]-without the surroundings of a court [renewed cheers]-without nobles, except such as are made by eminence in intellect and virtue-without State bishops and State priests, those venders of the love that works salvation [cheers]-without great armies and great navies-without a great debt and great taxes -and Privilege has shuddered at what might happen to old Europe if this great experiment should succeed. 


\section{THE UNITED STATES}

That this was no exaggeration of the feeling of the governing classes has been admirably demonstrated by Prof. E. D. Adams in his little pamphlet entitled, Great Britain, America, and Democracy. He quotes from the Morning Post: "If the Government of the United States should succeed, .. . Democracy will have achieved the greatest triumph since the world began. It will have demonstrated to the ample satisfaction of its present and future proselytes that it is even more puissant in war than in peace." And from the Edinburgh Review: "It is precisely because we do not share the admiration of America for her own institutions and political tendencies that we do not now see in the impending change [success of the South] an event altogether to be deplored. In those institutions and tendencies we saw what our own might be if the most dangerous elements of our constitution should become dominant. We saw Democracy rampant, with no restrictions upon its caprices." Professor Adams's conclusion is that "in England the basic opinion of our war was of 'democracy on trial,' and men took sides as they desired or opposed an expansion of democracy in England." And this, in general, was what the Civil War signified to Europe: the success of the great experiment in democracy depended upon whether the 


\section{AN EXPERIMENT IN DEMOCRACY}

union of the states could be preserved, and so reconstructed as to retain the essential spirit of a free and popular government.

The Civil War may thus be justified on the ground that the preservation of the Union was of decisive importance in the history of free institutions. From this point of view the significance of the war has once for all been expressed in the imperishable words of President Lincoln's address in commemoration of the soldiers who fell at Gettysburg:

Fourscore and seven years ago our fathers brought forth on this continent a new nation, conceived in liberty and dedicated to the proposition that all men are created equal. Now we are engaged in a great civil war, testing whether that nation, or any nation so conceived and so dedicated, can long endure. We are met on a great battle-field of that war. We have come to dedicate a portion of that field as a final restingplace for those who here gave their lives that that nation might live. It is altogether fitting and proper that we should do this. But in a larger sense we cannot dedicate, we cannot consecrate, we cannot hallow this ground. The brave men, living and dead, who struggled here have consecrated it far above our poor power to add or detract. The world will little note, nor long remember, what we say here, but it can never forget what they did here. It is for us, the living, rather to be dedicated here to the unfinished work which they who fought here have thus far so nobly advanced. It is rather for us to be here dedicated to the great task remaining before us-that from 


\section{THE UNITED STATES}

these honored dead we take increased devotion to that cause for which they gave the last full measure of devotion-that we here highly resolve that these dead shall not have died in vain - that this nation, under God, shall have a new birth of freedom-and that government of the people, by the people, for the people shall not perish from the earth.

In this brief address of scarcery more than two hundred words, delivered within the space of two minutes, an address which by common consent ranks among the classics of English speech, Abraham Lincoln revealed the essential significance of American history, and of the Civil War as a part of that history, both for the New World and for the Old.

But the war could scarcely have been justified on this ground, on this ground, precisely, it could indeed have been condemned, if the Southern claim to independence had rested upon permanent and ineradicable differences of race and language and of traditional custom. This was not the case. The fundamental and ultimately the sole cause of quarrel was slavery; and slavery was not only contrary to the trend of modern economic development and of modern thought, but flagrantly and completely contrary to the ideas in behalf of which the United States won its independence from Great Britain, as well as to the spirit of its political institutions. 208 


\section{AN EXPERIMENT IN DEMOCRACY}

The social philosophy by which the South justified slavery was a denial of America's birthright; and precisely because the war to preserve the Union was justified as a test whether a nation "conceived in liberty, and dedicated to the proposition that all men are equal," could long endure, such a war would have been meaningless if, in preserving the Union, it had not destroyed the one thing which made the preservation of the Union useless. In effect, therefore, if not in origin, the Civil War was a war for the abolition of slavery as a menace to popular government and of everything which made America of peculiar significance to the world.

Before the end the North began to realize that if the war did not bring about the destruction of slavery it would have been fought in vain. No question was on President Lincoln's mind more than precisely this problem of the relation of slavery to the war. Lukewarm conservatives were afraid that he would use his power as commander-in-chief of the army to declare the slaves emancipated; and impatient Abolitionists criticized him for timidly refusing to emancipate them. After eighteen months of war, Horace Greeley, in an editorial in the New York Tribune, demanded in behalf of "twenty millions" of people that the President should abandon a 


\section{THE UNITED STATES}

policy of vacillation and come out at once in favor of emancipation. In reply to Greeley, Lincoln wrote a brief and masterly letter in which he annihilated his passionate critic by a simple and lucid statement of his policy.

As to the policy I "seem to be pursuing," as you say, I have not meant to leave any one in doubt. I would save the Union. I would save it in the shortest way under the Constitution. The sooner the national authority can be restored the nearer the Union will be "the Union as it was." If there be those who would not save the Union unless they could at the same time save slavery, I do not agree with them. If there be those who would not save the Union unless they could at the same time destroy slavery, I do not agree with them. My paramount object in this struggle is to save the Union, and is not either to save or to destroy slavery. If I could save the Union without freeing any slave, I would do it; if I could save the Union by freeing all the slaves, I would do it; and if I could save it by freeing some and leaving others alone, I would also do that. What I do about slavery and the colored race I do because I believe it helps to save the Union; and what I forbear I forbear because I do not believe it would help to save the Union. I shall do less whenever I believe what I am doing hurts the cause, and I shall do more whenever I shall believe doing more will help the cause. I shall try to correct errors when shown to be errors, and I shall adopt new views so fast as they shall appear to be true views.

On first reading, this letter seems to display a marked indifference to slavery, and one 


\section{AN EXPERIMENT IN DEMOCRACY}

wonders why the President placed the preservation of the Union above everything else. Probably few men ever hated African slavery with a more intense hatred than Abraham Lincoln. Yet he put the safety of the Union first. The reason for this was that he believed everything else depended upon it. If the Union were dissolved, so he thought, not only would the bright promise of free government be lost, but the best chance of freeing the slaves would be lost, too. Freedom in every sense, in the personal and in the political sense, depended upon preserving the Union. To have proclaimed the freedom of the slaves would have been a mere aimless gesture in the air if the South could not be brought back into the Union. The question which the President had to consider was, therefore, this: What effect would an emancipation proclamation have upon the outcome of the war? Would it strengthen or weaken Northern support of the war? Would it strengthen or weaken Southern resistance?

In the early months of the war, when the South was victorious in a military way, the President judged, and rightly, that a proclamation of emancipation would strengthen the Southern States in their determination never to re-enter the Union with the North, at the same time that it would alienate a great body 


\section{THE UNITED STATES}

of Northern people who were unwilling to fight for the freedom of the negroes. Above all, the President was endeavoring to win over certain "border" slave states-states like Kentucky, where pro-slave sentiment was not so strong and where a good proportion of the people were opposed to secession. To interfere with slavery would tend to drive these border states into the arms of the Southern Confederacy. The President was, therefore, waiting for the day when moderate Northern sentiment should be ready for the policy of emancipation, and when the attitude of the border slave states would no longer be seriously affected by such a policy.

But aside from all this, Lincoln was looking beyond the war to the conditions that would make for a just and lasting peace. He hoped for a peace which, without conceding the Southern claims, would effect, if possible, a genuine reconciliation between the two sections. If the Union were to be preserved, the people of the North and the people of the South would have to live together; it would be better if they could live together in harmony, without bitterness and rancor, "with malice toward none, with charity for all." The President would therefore have been glad if the preservation of the Union could have been secured and slavery abolished by 


\section{AN EXPERIMENT IN DEMOCRACY}

a diplomatic instead of by a military victory. His policy in respect to slavery was closely connected with this idea. In the first years of the war he hoped that a policy of emancipating the slaves with compensation to the owners might win over a sufficient number of the slave states to make it hopeless for the rest to continue the struggle. If this could be accomplished the great objects of the war would be attained; slavery would be abolished and the Union preserved-preserved in the most effective way, without the aftermath of sectional bitterness which was likely to follow a war waged to the bitter end and a peace founded upon military conquest and enforced at the point of the sword.

Unhappily, this outcome was impossible. Neither the North nor the South was prepared to accept such a program; the South would not accept emancipation on any terms; the North would not concede compensation. As soon as the President was convinced of this, he was ready to proclaim emancipation as a military measure, and it is a significant fact that when he wrote his famous reply to Horace Greeley there was already lying in his desk the draft of an emancipation proclamation. He was waiting only for a favorable turn in the military situation. Accordingly, on the $23 \mathrm{~d}$ of September, 1862 , six days 


\section{THE UNITED STATES}

after General Lee's invasion of Maryland was checked at the battle of Antietam, President Lincoln proclaimed the unconditional freedom of all the slaves within those states which should still be in arms against the federal government on the Ist of January, I863. But the South was confident of victory. At the opening of the new year none of the confederated states had made its peace with the federal government. The war was, therefore, fought to the bitter end; and the Southern States, without their slaves and without compensation for them, were compelled to reenter the Union as the result of a complete military conquest.

The Civil War settled two questions: it abolished chattel slavery, and it preserved the Union in the sense that it established the doctrine that this is "an indestructible union of indestructible states." These questions the war settled permanently. Two other questions, which grew out of the war, were left for the future: the reconciliation of the Southern people, and the status of the liberated colored race.

It was to be expected that four years of civil war, carried on to the bitter end, would leave their heritage of sectional rancor and animosity. Under the circumstances, the task of reconstructing the political union on just 


\section{AN EXPERIMENT IN DEMOCRACY}

principles, and in a manner likely to reconcile the Southern people to their defeat as quickly as possible and to enable them to resume their political functions without undue humiliation, was an exceedingly difficult one. It might have been accomplished had President Lincoln been spared to shape the policy of reconstruction in the humane and enlightened spirit of the second Inaugural Address-"With malice toward none, with charity for all." But such a spirit was not to prevail. At the moment of victory the President was shot down in cold blood by John Wilkes Booth, a self-constituted avenger of the South. It was the most senseless crime recorded in political history, for it deprived the South of its best friend and the North of its wisest leader - the one indispensable reconciler of a disunited and embittered nation.

President Lincoln's just and humane policy of reconstruction was adopted by his successor; but Andrew Johnson, although an able and well-meaning man, was in origin and by temperament wholly unfitted for the high responsibility which was thus thrust upon him. He assumed all the authority of his office, although it was a mere accident and no popular mandate that placed him in it. No man ever needed a reasonable and conciliatory temper so much who possessed so little of 


\section{THE UNITED STATES}

either. An irreconcilable misunderstanding at once developed between the President and the Congress, in which the latter gained the upper hand, and a disastrous policy of reconstruction was finally carried out in a futile spirit of punishment and revenge under the leadership of embittered fanatics such as Charles Sumner and Thaddeus Stevens. The Southern people accepted their defeat, but they were unwilling to confer immediately upon all the freedmen those civil and political rights which would have given to a densely ignorant and hopelessly incompetent race an ascendancy in many Southern states. The North in turn refused to admit the Southern States into the Union on any other terms. To attain these ends, the South was accordingly subjected for some years to military occupation; the Southern whites were practically excluded from all political functions; and under the protection of the Northern army, the negroes, unscrupulously led and exploited by Northern political adventurers called "Carpet-baggers," organized the new state governments which accepted the Northern terms, in the form of the Fourteenth Amendment to the Constitution, and were then admitted to the Union.

The Carpet-bag régime, in which the whites took practically no part, was a travesty upon 


\section{AN EXPERIMENT IN DEMOCRACY}

the principle of self-government and a disgrace from every point of view. It precipitated a condition of confusion, of political corruption, and of social anarchy such as the war itself never produced; and although it forced the South to accept the Northern terms, it failed to accomplish the object which those terms were designed to accomplish-it failed. to confer permanently upon the colored race an equality of civil and political rights. As soon as the Northern army was removed the Southern whites resumed control, and the negroes were immediately, and have since remained, practically disfranchised. In form the Union was restored, but in spirit it remained divided; and the aftermath of bitterness and rancor which divided the sections for a generation was due not so much to the war itself as it was to the experience of the reconstruction era. The Southern people accepted defeat, they accepted the abolition of slavery, and they were in the way of recognizing that they fought not only a losing cause, but a bad one; but the ruthless, undemocratic, and humiliating domination forced upon them during the Carpet-bag régime, and the economic exploitation which accompanied it, they could not forget and did not forgive. The result was a "Solid South," which remained unreconciled for forty years, and which to this 


\section{THE UNITED STATES}

day votes as a unit against the Republican party, which sought in vain to confer political privileges and to reconstitute national unity at the point of the bayonet. The good results of "unconditional surrender" in the military sense-of General Lee at Appomattox-were half lost by the "unconditional surrender" in the political and moral sense which the North imposed upon the South after it had admitted defeat and laid down its arms.

It has been well said that slavery was only the worst solution of the negro problem, and that while the war abolished slavery as a bad solution of the problem, it did nothing to abolish the problem itself. This is profoundly true; and it was in large part because the Northern leaders failed to recognize this truth that the reconstruction policy proved a fiasco. The negro could be freed by force of arms; by force of arms civil and political rights could be conferred upon him in a formal and legal sense; but force of arms was helpless to make these rights a reality because neither force of arms nor legal decrees could bring about an assimilation of the two races or compel the ancient masters to recognize their former slaves as equals. Thus it is that although the war abolished slavery, and the Fourteenth Amendment conferred civil and political rights upon the freedmen, the prob218 


\section{AN EXPERIMENT IN DEMOCRACY}

lem of the colored race, and the problem of making our democracy work in respect to the colored race, remains still unsolved.

There are to-day about ten million people of African or of mixed African and Caucasian descent in the United States-mainly in the South; and they remain to-day, as they were before the war, an inferior class. It could not, of course, be otherwise than that a people so long enslaved and so recently emancipated should still be, on the whole, poorer, more ignorant, and more debased than the white descendants of people who for centuries have been among the most civilized in the world. This in itself would not make the problem of the colored race a special and particularly difficult one. There are perhaps as many poor, ignorant, and debased people among the white inhabitants of the United States. What makes the problem of the colored race a serious one is the fact that they are a class apart. The inferiority of the colored man is not an individual, but a racial matter; however prosperous, intelligent, or cultivated a black man becomes, he is still, in virtue of being a black man, in a position of inferiority as compared with white men of similar attainments and capacities.

The amalgamation of the two races would in any case be slow because of the radical 


\section{THE UNITED STATES}

differences, mental and physical, which keep them apart. But that this would not be an insuperable barrier is proved by the large number of people of mixed blood among the colored population. What the whites object to is intermarriage with negroes, and to associating on equal terms with them; and the chief reason for this is the indelible stigma which the tradition of slavery has placed upon them. The Southern people very frankly maintain the pre-war attitude of mind in respect to their relations with the colored race. They like the negro well enough in a condescending way; they have for him less instinctive physical repulsion than the Northerner has, and they are even more disposed to treat him kindly-as long as he "keeps his place." But his "place" is still one of inferiority; in every respect, except in legal status, the colored race is still regarded in the South as a servile and an outcast class. The attitude of the Northerner toward the negro is much the same, although the Northerner is less frank in admitting it. On the whole, the Northerner dislikes the negro more than the Southerner does, understands him less well, has less patience with his habits and idiosyncrasies; and however much he may say that this repulsion is a mere prejudice, that the colored man is "as good as 


\section{AN EXPERIMENT IN DEMOCRACY}

any one else" and ought to be treated as an equal, he does not commonly treat him as an equal; in spite of theories and good intentions, some subtle repulsion keeps the two races apart, in the North no less than in the South.

The negro is not only in a position of social inferiority; in the economic field he labors at a great disadvantage. Carefully prepared statistics show that the per capita wealth of the negroes throughout the country is $\$_{34}$, while that of the whites is $\$ 885$ in the South and $\$ 1,320$ in the North. That a people so recently emancipated should be poor is natural enough, but the natural economic backwardness of the negroes is accentuated by the social prejudice which virtually closes many occupations to them, or restricts their advancement in such occupations as they may enter. Apart from all natural or racial handicaps, it is still true that the negro in the United States does not enjoy an equal economic opportunity with the white man of similar intelligence and industry.

To the social and economic disadvantages must finally be added a marked political discrimination. The federal Constitution confers upon the negro the same right of voting which white men possess; but the social prejudice and economic inequality under which he 


\section{THE UNITED STATES}

lives and labors, in the Southern States especially, give such an ascendancy to the whites that it is possible for them practically to exclude the negro from any effective exercise of his political rights. In spite of the Constitution, the colored people are in fact a disfranchised people in all the Southern states. Thus it happens that, so far as the ten million colored people are concerned, American democracy does not work, or at least it works badly. The negro is an American, but he is an American who remains apart, unassimilated with the white population, economically still a servile class, socially inferior, and politically unfranchised.

If slavery was a menace to free institutions, the existence of this unassimilated class, which is regarded as inferior and practically treated as such, is also a menace, in however less a degree, to free institutions. It may be true that the United States was "conceived in liberty, and dedicated to the proposition that all men are created equal"; but it must be admitted that there is an ugly contrast between the actual fact and the ideal profession so long as one-tenth of the population is deprived of its liberty and treated as inferior on account of its "race, color, and previous condition of servitude." Perhaps the problem is unsolvable; if so, it must be noted as one 


\section{AN EXPERIMENT IN DEMOCRACY}

of those situations to which our democratic formula does not apply.

No doubt the practical application of any ideal of government and society can never be perfect; and it is obvious enough that democracy works best in communities where there is a great degree of homogeneity in the population. There are exceptions to the rule, as, for example, Switzerland (even in Switzerland it is a question whether the lack of homogeneity is not more apparent than real); but generally speaking, where racial or cultural or economic interests tend to divide the population into distinct groups, and where the difference between the groups tends to become deep-seated and permanent, there the practical application of democratic principles becomes difficult or impossible. Such group differences are common and chronic in many European communities; but in the United States the unassimilated negro group is the more striking phenomenon precisely because of the astonishing rapidity with which the great number of foreign immigrants has been assimilated. The people of the United States have been recruited from every country of Europe; but hitherto the characteristics of nationality, of language and culture, which distinguish the immigrant when he arrives have disappeared within a generation; his 


\section{THE UNITED STATES}

children have become Americans, indistinguishable from the general type. Hitherto the negro, and perhaps certain Oriental peoples like the Chinese, have seemed to be the only people whom the American nation has not been able to assimilate readily.

But in recent years the process of Americanizing even the European immigrants has come to be less rapid and less complete. There are now more numerous and larger groups of people speaking a foreign language in the United States than ever before; and these groups, under certain conditions, tend more and more to persist as groups apart, like the negro unassimilated to the general type, and like the negro regarded in some measure as economically servile and socially inferior. The negro problem is thus no isolated problem; it is a part, although no doubt the most difficult part, of a larger problem which confronts democracy in this country. This problem is the problem of Americanization-of assimilating diverse racial and economic groups to a common type, with common interests and ideals. 


\section{VIII}

DEMOCRACY AND IMMIGRATION

IT is sometimes said that the Monroe Doc1 trine is the expression of a policy of selfish isolation. By insisting upon this policy, so it is claimed, the United States virtually says to Europe, "Since we have got, by our own efforts and the favor of Providence, a very fine country, we prefer to enjoy it ourselves; you will therefore kindly mind „your own business and we will mind ours." This is indeed the substance, put in very undiplomatic language, of what the United States has said to the governments of Europe, but it is the very opposite of what it has said to the people of Europe. To the people of Europe the United States has said: "We do not want your political system over here, but we do want you - the more the better."

To this generous invitation the people of Europe have responded. From colonial days they have come in ever-increasing numbers, 


\section{THE UNITED STATES}

and in an ever greater diversity of language, of religion, and of nationality. In the year I9I0 more than a million foreigners, excluding those from Canada and Mexico, came to this country. If they had all landed at the port of New York, as in fact most of them did, and if their arrival had been uniformly distributed throughout the year, one might picture them coming down an imaginary gang-plank at Ellis Island about 3,000 every day, I 20 every hour, day and night, 2 every minute, a continuous stream of people of both sexes, of every race and language and religion of Europe, abandoning their native land to come to America. Why do they come? What do they seek?

The motives of the immigrants are of course many, varying with the country, the class, the race from which they come; but in a general way it may be said that the people of Europe have come to the United States in such large numbers because it has been, or they have imagined it to be, a land of liberty, of opportunity, above all, of economic opportunity. What America was to the European peasant in the eighteenth century is indicated by St. John de Crèvecœur's description in his Letters of an American Farmer, printed before the Revolution. In America, he says, the rewards of a man's industry 


\section{AN EXPERIMENT IN DEMOCRACY}

follow with equal steps the progress of his labor; this labor is founded on the basis of self-interest. Can it want a stronger allurement? Wives and children, who before in vain demanded a morsel of bread, now fat and frolicksome, gladly help their father to clear those fields whence exuberant crops are to arise to feed them all; without any part being claimed either by a despotic prince, a rich abbot, or a mighty lord.

More than a century later the United States was still regarded as the land of economic opportunity. Mr. Warne, in his book entitled, The Immigrant Invasion, quotes the following statement from the United States consular reports:

It would be difficult to state any one particular reason why these plain, poor, hard-working people from the plains of Russia and the hills and valleys of Austria, should leave their Fatherlands, their humble homes, their friends and the traditions of their forefathers, and scramble for passage on a steamer bound for a far-off, strange country. It cannot be that their home country is overcrowded, for the majority of them crowd into our cities. Undoubtedly, in some cases they leave because they love peace and resent forced military service. Again, others forsake their old homes, impelled by the love of freedom. But of such idealists there are probably very few indeed. The vast majority go because our country is known to them as the land of promise, the land of opportunities greater than their country can offer. The great discontent among the laboring classes of Europe, stimulated by rumors of great prosperity in the United States, is the prime cause of this wonderful exodus. 


\section{THE UNITED STATES}

For a hundred years the peasants of Europe have echoed the sentiment of Goethe"America, du hast es besser!" They have come to America because, in contrast with Europe, America has the best of it. What have they found in America? Have they found the freedom, the economic opportunity which they sought? What have they contributed to America? How have they modified the national character? Have they furthered or retarded the great experiment in democracy? These are questions of importance in any consideration of American ideals and institutions.

\section{II}

The average American is scarcely aware of the continuous influx of foreigners. He does not see them landing every day at Ellis Island. $\mathrm{He}$ rarely comes into any direct contact with them, either in the great industrial plants or in the slums of the great cities where they live together in comparative isolation. He does not even see many of them on the streets, because his streets are not their streets. If his attention is called to the question of immigration he is likely to take it as a matter of course, as something that has always been going on, and he will very likely dismiss the whole problem by saying, "Well, we absorb 228 


\section{AN EXPERIMENT IN DEMOCRACY}

these people very easily; our institutions Americanize them, make new men of them, in the second generation." This, of course, is precisely the important question. Do we Americanize them? Do they, by any chance, or to any extent, de-Americanize us?

If we wish to get the average American really interested in this question, it will be well to lay before him a good many statistics. Americans think in numbers more easily than in any other way. They have a saying that "Figures don't lie," and if you can make them see the immigrant question in terms of "figures" it will at once take on a vividness that it could not otherwise have. First of all, therefore, let us startle our average American by telling him that in I9Io there were in the United States 13,000,000 inhabitants who were born in some foreign country. This was roughly one-seventh of the total population; and this means that if these 13,000,000 people were uniformly distributed throughout the country, the average American, when he went about his business or pleasure, would find that one out of every seven persons he met was, in respect to birth, nationality, and inherited traditions, to all intents and purposes a foreigner. Only a very small per cent. of these foreign-born were under fifteen years of age when they arrived in the country; and 


\section{THE UNITED STATES}

the average American may therefore rightly be told that he, assisted by six other average Americans, is in duty bound to "absorb" and "Americanize" one full-grown foreigner; and furthermore, at the present rate of immigration we can give him only about sixteen years to do it in, for at the end of that period we shall have another foreigner to turn over to him and his six associates.

If the business were managed in this way, the average American would doubtless think it a bigger job than he had supposed. But

- another thing which the American does not sufficiently realize is that the number of immigrants is constantly increasing. This increase may be made vivid by the following figures. Between 1820 and I9IO the total immigration from foreign countries, excluding Canada and Mexico, was about 28,000,000; between 1850 and I9IO it was about 25,000,oo0; between I880 and I9IO it was about 19,000,000; between 1900 and 1910 it was about 9,000,000; and between 1905 and 1910 it was about 5,000,000. If the number of immigrants had been as great every year from 1820 to 1910 as it was in the year I9IO, the total immigration for the period I820-I9Io would have been about 90,000,000 instead of $28,000,000$. Therefore we must tell our average American that if the number of immi- 


\section{AN EXPERIMENT IN DEMOCRACY}

grants goes on increasing in the future as it has done in the past, he and his six associates will be required, as time goes on, to complete the process of Americanizing one foreigner within considerably less than sixteen years.

As a matter of fact, the immigrants are not uniformly distributed throughout the country; and while it is this fact that enables the average American to dismiss the problem as one that easily solves itself, it is in reality this fact that makes the problem more difficult than it would otherwise be. In some parts of the country there are almost no immigrants at all; in other parts they are more numerous than the native-born. In the state of Kansas, for example, the people are almost entirely relieved of the task of Americanization. But in New York City only about one person in five is a native-born of native parents; the rest are either native-born of foreign parents or are foreign-born; about $1,500,000$, that is to say, about one-third of the total population are foreign-born. This situation concentrates the problem of Americanization in certain areas; New York has much more and Kansas much less than its proper share of the common task. And in recent years there has been a much greater concentration of immigrants in certain areas than formerly; so that the problem of 


\section{THE UNITED STATES}

Americanization is becoming a more difficult one, not only because the number of immigrants is increasing, but also because they are being distributed less uniformly among the people as a whole.

The difficulty of Americanizing any given number of foreigners, whether they are more or less uniformly distributed, will depend also upon what kind of foreigners they are. It will obviously be easier to make an American out of a foreigner who already speaks the English language than out of one who does not; and easier to make an American out of an intelligent than out of an illiterate foreigner, whatever his nationality. If we look at immigration from this point of view, we find that in the decade ending 1850 about twothirds of the total number of immigrants came from Great Britain, Ireland, and Canada, and were accordingly English-speaking people; whereas in the decade ending I9IO considerably less than one-third came from these countries. The proportion of foreigners speaking an alien tongue has therefore constantly increased. Besides, the quality of the immigrant has apparently deteriorated. Of the immigrants who came prior to the decade ending in 1880 , only about 3 per cent. were illiterate-that is, could neither read nor write their own language, whatever it was; 


\section{AN EXPERIMENT IN DEMOCRACY}

but of those who have come since I880, about 35 per cent. were illiterate.

There is still another factor which enters into the problem of Americanization. A foreigner who comes to live in America will think of himself as an American much more readily, and will take on American habits and customs much more rapidly, if he finds that he is able to engage in the same occupations that native Americans engage in, to live in the same kind of houses, eat the same kind of food, wear the same kind of clothes, and enjoy the same kind of recreation and amusements. He will then feel that he is an American because he is getting out of life the same things that the average American gets. But if he finds himself doing only the more disagreeable kinds of work, receiving the lowest wages, and consequently living a life which no native American will consent to live, then he is likely to feel that America is not the promised land of opportunity which he supposed it to be. Since he gets less than Americans get, he will not feel himself an American, which is much the same thing as not being one.

Now, in fact, this is coming to be more and more the case. The immigrant finds himself working in certain industries at wages which Americans will not accept, and living 


\section{THE UNITED STATES}

in certain sections of our great cities under conditions that are often worse, and rarely better, than those in which he lived in the Old World. He finds himself associating mainly or altogether with other foreigners like himself. Since they do not commonly meet or deal with native-born Americans, there is slight incentive and no necessity for learning the language, or for adopting American customs. They often remain foreigners, foreigners in appearance and foreigners at heart. Since America exploits them, they will, so far as they can, exploit America. Their aim too often is, not to become Americans, but to return to Europe when they have acquired a little money, which many of them do acquire by good luck, or by dint of living the barest and most squalid lives. Since 1880, about 40 per cent. of the total number of immigrants have gone back to Europe, and of this 40 per cent. about two-thirds have remained there. These returning immigrants do not commonly tell their friends that America is the promised land, the land of freedom and of equal opportunity. They describe America as they have found it - a country dominated by capitalists, a sordid bourgeois society without ideals, a land of "dollar-chasers" where wealth controls the government and exploits the people. 


\section{AN EXPERIMENT IN DEMOCRACY}

\section{III}

The average American would be somewhat surprised to learn all this; he would perhaps be a little skeptical, because he has always understood that the ease with which foreigners have been absorbed and Americanized is one of the seven wonders of the world. America has been called the "melting-pot"- a continuously bubbling sociological kettle into which we have grown accustomed to thinking you could throw no matter what number or variety of foreign elements, without materially modifying the resulting product; the end of the melting was supposed always to be the pure gold of Americanism. This, according to the average American, is what comes of having true democratic institutions.

It is true that for the most part the meltingpot has worked very well. Until recent years the successful transformation of the foreignborn population into "typical" Americans within a single generation has been one of the notable achievements of the United States. It is true also that this happy result has been due in some measure to the character of our institutions; but it has been due far more to the absence of those conditions which make Americanization difficult - it has been due to the dispersion of the immigrants among the 


\section{THE UNITED STATES}

mass of the people, to the relative excellence of the immigrant population, and to the opportunity of the immigrant to live the life and enjoy the rewards of the ordinary American. Generally speaking, these favorable conditions prevailed up to a period which may be roughly placed in the decade from 1880 to 1890 . It will be noted that this is also the date which marks the end of the era of an abundance of free land, the end of strictly frontier conditions. The coincidence is not accidental; on the contrary, the problem of immigration and of the Americanization of the foreign-born is intimately connected with the disappearance of free land, and with the industrial transformation which has followed the disappearance of free land.

In the earlier period-using this term to designate roughly the period before 1880the immigrant was most likely to be Irish or German, or if he was neither of these he was almost sure to be Scotch, Welsh, Canadian, or English. Not until the decade ending in 1870 did the Scandinavians begin to come; not until the next decade did the immigration from southeastern Europe begin. The great Irish migration of the period I840-80 was largely due to intolerable conditions at home - to bad harvests and to bad laws; and it was, on the whole, the most intelligent and energetic of 


\section{AN EXPERIMENT IN DEMOCRACY}

the Irish peasantry that came to America. The German migration to the United States has been pretty constant, but it reached its greatest extent between 1850 and 1890 . In this period, powerful influences in driving Germans to America were the failure of the liberal political movements of 1848 , the harsh military service imposed upon the people, the relative lack of industrial opportunity. Aside from the Germans, practically all of our immigrants spoke English as their native tongue; and among them, as among the Germans also, the percentage of illiterates was very low. In addition to this, the number of immigrants in this early period who returned to Europe was small; and while the fact that an immigrant remained permanently in the United States does not necessarily mean that he came with that intention, the presumption is that he did so; and therefore we may say probably that a great proportion of the early immigrants came to this country with minds favorably disposed to becoming American citizens. In all of these respects our early immigrants were generally, by virtue of their English speech, of their intelligence and character, and of the state of mind with which they contemplated their new home, a class of people whom it would not be difficult to Americanize.

The process of Americanization was greatly 


\section{THE UNITED STATES}

facilitated by the situation in which the immigrant was likely to find himself after he arrived. The Irishman was more disposed than any others to settle in the cities, but even in the cities opportunity was not lacking. Wages were high, and the industrious men soon enjoyed a way of life which would have been thought luxurious in old Ireland, while the clever ones found in local politics an opening which no one has ever excelled the sons of Erin in making the most of. Nevertheless, a great many Irish, and the great proportion of other immigrants, avoided the cities. They either came with the intention of becoming farmers or the liberal pre-emption and homestead laws made them such after they arrived. Indeed, the striking aspect of immigration before 1890 is the steady flow of the new-comers into the great agricultural Northwest. In the decade between 1840 and I 850 the total foreign-born population of the North Central states was only 641,000 , while that of the North Atlantic states was I,304,000; whereas in the decade from I870 to I 880 the number in the North Atlantic states was $2,815,000$, while the number in the North Central states had risen to 2,917,000. Besides, in this early period the concentration in the cities was much less than it has since become; so that, generally speaking, a very 


\section{AN EXPERIMENT IN DEMOCRACY}

large percentage of the early immigrants were dispersed in the rural agricultural communities, or in the small towns which are essentially parts of these communities; and this was particularly true of the Germans-that is to say, almost the only group that spoke a foreign language.

Under these circumstances it was difficult for the foreigner to resist the process of Americanization, even if he wanted to. I have myself seen this process of Americanization going on in a way that is fairly typical of the earlier period. My own parents were descended on the one side from Dutch and German ancestors who came to New York probably in the eighteenth century, and on the other side from English and Irish ancestors who came there-I have no idea when. My paternal great-grandfather could not speak anything but German; my father could not speak anything but English, nor could any one have guessed, either from his appearance or from any tone or quality in his speech, that he was of other than English descent. In 1867, having served three years in the Civil War, he decided, like thousands of others, to abandon the state of his birth in order to acquire much better land at a much lower price in the new West. He accordingly went, first to Illinois, and afterward 


\section{THE UNITED STATES}

to Iowa, where he bought eighty acres of as good farm land as there is anywhere to be found, for which he paid, I think, about eight dollars an acre, and to this he afterward added two other "eighties." It was on this Iowa farm that I was born.

One of my earliest recollections was the appearance in our neighborhood, it must have been about 1878 , of a strange family that came to live in the house across the road. To me, a "typical" American boy, they seemed outlandish folk whom one would naturally avoid as suspicious and yet wish to see from some safe point of vantage as a curiosity. The reason for this primitive attitude of mind toward the new-comers was that they were Germans who could barely speak a word or two of English; and a "typical" little American boy, who was himself descended from English, Irish, Dutch, and German ancestors, and whose great-grandfather could not speak English, had never in his life seen nor heard of a German, and now learned for the first time this marvelous thing-namely, that there were people in the world who could not talk as he did, but spoke a kind of gibberish which it was alleged they understood, although no one else did. The typical little American boy doubted, like Doctor Johnson, whether they could really understand themselves; and he 


\section{AN EXPERIMENT IN DEMOCRACY}

wondered why they had not been taught to speak like other people.

, Naturally enough, the little American boy had no desire to learn this strange gibberish, nor would he ever make the slightest effort to learn it. Afterward, when he became the daily companion of the children of this German family, and sometimes found himself inveigled by them into their house in order to get something to eat "between meals," the grown-up Kate, of whom he was much afraid, would perhaps make it a condition of his getting anything that he should say, "Bitte, ein stück Brot." But the little American boy would never even try to make these strange sounds; not even the great desire for bread and molasses (which he always got, anyway, in the end) would bring him to it. Never, on any occasion, would he say even a single word, such as Brot, or Messer, or Tish; for the truth is that the little American boy could see no sense in these words, or any good reason for learning to pronounce them.

And indeed, in his own way, the little American boy was quite right. He never needed to speak German; and no one in that Iowa farming community ever needed to speak German. To speak nothing but German was as great a handicap as any one could well have; and the German family knew this 


\section{THE UNITED STATES}

better than anybody. They had to learn English, and all of them did, except the mother. The father soon learned to say all that he needed to say, in a strange, throaty fashion that never lost its interest for the little American boy, and the children learned more easily still to speak English as well as German, and no doubt much better in the course of time. They went with the little American boys and girls to the "district school," where they studied the same books and played the same games and acquired the same manners as other boys and girls. Between this German family and other families there was no difference, except the difference in origin. The man paid for his farm, just as my father paid for his. He ultimately "retired"-that is, he rented his farm and went to live in town on the rental of his farm-just as my father did. His children married, either the children of other German-Americans or else native Americans (one of them married my cousin), and they now have children of their own who go to the schools, join the Methodist or the Baptist or the Congregational Church, will become Democrats or Republicans, as the case may be, and probably cannot in any case speak any language but English. Such was the process of Americanization throughout the farming communities of the great Middle West. 


\section{AN EXPERIMENT IN DEMOCRACY}

The process has been much the same in the small towns. Many years afterward, the little American boy who would not learn German (much to his subsequent regret) came to live in another Middle-Western state, in a town or small city of some fifteen thousand inhabitants. This town, which we may call $\mathrm{X}-$ was a typical Western community in the center of a rich farming country. It was a prosperous "business" town in a small way, and, as usually happens, the home of some more pretentious enterprises. Most of the inhabitants of this town were "typical" Americans, and most of the shops and banks and industrial undertakings were owned and controlled by them. In the town of $\mathrm{X}$ - there were, however, the usual small number of GermanAmericans-men of German birth who had become naturalized American citizens, and among these were two or three families, interrelated by marriage, who had built up a very suceessful wholesale business. They were, if not wealthy in the metropolitan sense, at least wealthy in the small-town sense. In a business way, the men were intimately associated with the "prominent" and "solid" citizens of the place, while in a social way they ranked without question among the "best people."

One of these men, whom we may call Mr. 


\section{THE UNITED STATES}

$\mathrm{B}-$ - I happened to know better than the others. He was born in Hanover, as I recall, of upper-middle-class parents, was educated at a German university, and came to America as a young man, where he married the daughter of German-born American citizens. As a matter of course, both of them spoke English, Mrs. B- without any trace of a German accent, Mr. B — with a delightful Teutonic tang. Necessarily, in fact, in this American community, English was the language which they customarily spoke, but they both spoke German well, they had twice visited Mr. B_- s parents in Germany, and they wished, naturally enough, that their three children might speak German as well as English. This they thought would be easily achieved ; the children would learn German from their parents and English from their playmates. Mr. and Mrs. B- did their best, but they failed. They spoke German to the children from an early age-at least, when they remembered that this was what they had decided to do. But the children only listened in German; they would reply in English. The children all went to the high-school, and there they studied German, which they disliked as much as most American children dislike it, and with about the same result. Later they went to the university, and there also they studied 


\section{AN EXPERIMENT IN DEMOCRACY}

German, and learned about as much of it as other American boys and girls learn. And the end of it all is that, in spite of the best of opportunities and the best of intentions, the children of Mr. and Mrs. B- cannot readily speak ten connected sentences of good German. If they should visit Hanover they probably could not hold intelligible converse with their grandparents and cousins. They are as much Americans as if their ancestors had come over on the Mayflower!

$\mathrm{Mr}$. B- is also an American, and must remain so. I do not know what he thinks of the Great War, and it does not greatly matter -except to himself. He very certainly has relatives who have fought with the German armies, very likely has some who have died in battle. His sympathies may or may not be with the Fatherland. The result is the same in either case. . His fortunes are inextricably bound up with this American community in which he lives. The efforts and the associations of thirty years, his business career and that of his son, the welfare and the happiness of his wife and daughters, tie him for good and for ill to this place and to these people. Whatever he may think in his heart, unless he is an extraordinary person indeed he must and he will act so that when he goes down the street a dozen friends 


\section{THE UNITED STATES}

and cronies will give him the kindly smile and the intimate "Hello, Fred!" which makes the day comfortable and life worth living.

\section{IV}

In the last quarter of a century the immigrant problem, the problem of Americanization, has become a much more difficult one. The immigrant is himself of a different type; he comes, or is brought over, for somewhat different purposes, and he finds himself, when he gets here, in a quite different situation from that which has just been described.

The immigration from Great Britain and Ireland has greatly diminished in recent years. Ireland has now scarcely more than one-half the population it had toward the middle of the nineteenth century; and on the other hand, thanks to the Irish legislation, it is, or was just before the war, a far more desirable place to live in. German migration has also fallen off. The rapid development of industrial life in Germany, together with the extensive social legislation favorable to the working-class, removed many of the conditions which formerly drove Germans to leave the Fatherland, while a good many of those who do go to South America rather than to the United States. The place of the Germans has been largely 


\section{AN EXPERIMENT IN DEMOCRACY}

taken by the Scandinavians, especially the Swedes; but the Swedes, although they have in considerable numbers become farmers in the Northwest, have more often taken entire possession of certain districts, as in Minnesota, where they are not assimilated by the native population, but form alien communities preserving their language and customs.

The striking fact, however, is that relatively few of the present-day immigrants become farmers. For the most part the best lands have been taken. Iowa land which in 1867 was purchased for $\$ 8$ per acre is now sold, some of it, for $\$ 425$ per acre. The immigrant finds, therefore, that he must either become a renter on this good land, paying nearly as much per acre in yearly rent as the land cost fifty years ago, or else he must go where land is cheaper because it is more remote or of poorer quality. In either case, and in spite of the high prices paid for farm products, when rent or interest is paid there is often little left for the necessities of life, and nothing for the luxuries. In addition to this, the farmers of the Northwest find that the price which they can get for their wheat is somehow determined by the great milling corporations of Minneapolis, while the meat-packers of Chicago, St. Louis, and Kansas City manipulate in their own interests the price of hogs and cattle. 


\section{THE UNITED STATES}

Inevitably, therefore, the agricultural communities no longer attract immigrants as they once did. The situation is vividly revealed in the simple fact that whereas in 1850 the average price of farm land in the United States was only \$II.33 per acre, and in 1900 was still only $\$ 19.30$, in 1910 it had risen to $\$ 39.50$, having more than doubled in ten years. These facts find their complement in the statistics of immigration distribution since $188 \mathrm{o}$. It will be remembered that the total foreignborn population in the North Central states (the distinctively agricultural states) steadily increased before that date until it numbered 2,917,000 as against 2,815,000 for the North Atlantic states (the distinctively industrial states). Since 1880 the great increase has been chiefly in the latter rather than in the former region. In I9Io the figures for the North Central states were 4,690,000, while those for the North Atlantic states were $6,676,000$. But this does not tell the whole story. After the year 1890 the increase in the North Central states was very slightamounting to less than a million in the twenty years from 1890 to 1910 . And this slight increase was evidently largely in the cities. During the decade from 1890 to 1900 there was actually a decrease of foreign-born population in every one of the North Central states except 


\section{AN EXPERIMENT IN DEMOCRACY}

North Dakota, Minnesota, and Illinois. During the same decade, out of a total increase of $1,092,000$ in the foreign-born population, all but 152,000 of this increase was in the six states of New York, Pennsylvania, Massachusetts, New Jersey, Connecticut, and Illinois - that is to say, the most highly industrialized states, with the exception of Illinois, in the Union. The meaning of this is clear; it means that in the twenty years before 1910 the great mass of the immigrant population, instead of being widely distributed over large areas and among the agricultural communities, was concentrated in the great industrial centers-New York, Pittsburg, the coal-mining regions of Pennsylvania, and the manufacturing towns of New Jersey, Connecticut, and Massachusetts.

A second characteristic of recent immigration is that the immigrants who come in such large numbers to work in the Bethlehem steelplant or the New England cotton-mills are less likely to be English-speaking people, less likely to be German. In the decade ending 1880 the immigration from Italy, AustriaHungary, Russia, and the Balkans was not more than 3 per cent. of the total; in the decade ending I9ro it was about 36 per cent. of the total. In 1870 the number of Slavs and Italian laborers in the anthracite coal 


\section{THE UNITED STATES}

region of Pennsylvania was 306, while the number of English-speaking laborers was 105,000; in 1910 the number of Slavs and Italians was 177,803 , while the number of Englishspeaking laborers was only 82,000 . In the decade ending I9 Io only about 28 per cent. of the total immigration was of English-speaking stocks, and in the same period the number of illiterates had risen to nearly 40 per cent.

The ignorant peasant or laborer or vagabond of any country, particularly of southeastern Europe, may well imagine America to be the land where life is bright and wealth easily obtained. The ignorant are certainly those who can be most easily made to think so by those who are interested in getting them to come. Undoubtedly the hopeless lot of many people in such countries as Russia and Italy, in parts of Austria-Hungary, in Greece and Bulgaria and Rumania, predispose them, at all hazards, to try their fortunes in the New World. But it is also true that much of the present-day immigration is "induced" or "stimulated" by those who have their own interests to serve. This has always been true to some extent. In the earlier period land companies desiring to sell their land, state governments wishing to populate their empty stretches of territory, and European governments willing to rid their countries of useless 


\section{AN EXPERIMENT IN DEMOCRACY}

or vicious classes, have all contributed to swell the tide of immigration.

Yet this sort of activity was probably never so notable, or so bad in its results, as now. On this point the United States CommissionerGeneral of Immigration, referring to the enormous increase of immigration from southern and southeastern Europe, has this to say in his report for 1910:

It is, to a very large extent, induced, stimulated, artificial immigration; and hand in hand with it (as a part, indeed, of the machinations of the promoters, steerers, runners, sub-agents, and usurers, more or less directly connected with steamship lines, the great beneficiaries of immigration) run plans for the exploitation of the ignorant classes which often place upon our shores large numbers of aliens, who, if the facts were only known at the time, are worse than destitute, are burdened with obligations in which they and all their relatives are parties, debts secured with mortgages on such small holdings as they and their relatives possess, and on which usurious interest must be paid. Pitiable indeed is their condition, and pitiable it must remain unless good fortune accompanies the alien while he is struggling to exist and is denying himself the necessaries of decent living in order to clear himself of the incubus of accumulated debt.

These helpless people, encumbered with debt, ignorant of English, many of them unable to read or write any language, ready to be herded into the first job that offers, are 


\section{THE UNITED STATES}

precisely the human material which many of the great manufacturing establishments are looking for. The competitive system of industry forces employers to look at labor as a commodity to be purchased as cheaply as possible and to be thrown aside when it is no longer worth the cost. Outside of business hours the average Âmerican employer is a humane and generous man; but he cannot afford, or thinks that he cannot afford, to bring sentiment, not even perhaps the sentiment of humanity, into his business; and he has not even the interest or the pride of ownership which would induce the master of a slave gang to see that his chattels were well fed and comfortable. His responsibility to the laborers ends when he has paid them the stipulated wage, and he somehow persuades himself that while the plant and the product belong to him, and must accordingly be the objects of his constant solicitude, the laborer does not belong to him and is therefore no concern of his; it is with the labor only, and with its price, that he has anything to do. Noblesse oblige, that sentiment which so often induces the wealthy American to bestow his wealth upon public institutions devoted to the welfare of humanity, is singularly absent in his dealings with the actual men and women who contribute to the production of that wealth. 


\section{AN EXPERIMENT IN DEMOCRACY}

The intelligent English-speaking American laborer understands this; and since the employer considers that his business is to buy labor as cheaply as possible, the laborer considers that he must sell his labor as dearly as possible. The long history of the labor-unions in the United States is the story of how intelligent labor has tried to organize so that the individual laborer may deal with the individual capitalist on equal terms and force him to pay a decent living wage. For many kinds of skilled labor the labor-union has been an effective means of keeping wages at a reasonably high level. But the more successful the unions are the more interested (falsely, no doubt) the employers are in obtaining a supply of labor that is not controlled by the unions. Nothing is therefore so well suited to the purposes of those great industries which require a great deal of unskilled labor as a continuous influx of ignorant, destitute, and helpless foreigners. It is this class of immigrants, coming largely from southeastern Europe, that they welcome; and these newcomers are steadily driving native American Tabor, as well as English-speaking immigrant labor, out of one industry after another. Slavs and Italians are replacing Irish, Scotch, Welsh, German, and English workers in the anthracite coal-mining industry; Poles and Armenians 


\section{THE UNITED STATES}

are replacing the Irish in the making of collars and cuffs; Poles and Italians are replacing the Irish and the English in the woolen, worsted, and cotton industries; Russians and Italians are replacing Germans in the manufacture of men's and children's clothing. And so it is in many other industries.

The new-comers drive out the native laborers not only because they are not controlled by the labor-unions, but because they are willing to live, or cannot in their ignorance and dire need refuse to live, in a way which the native will not endure. $\mathrm{Mr}$. Warne, in his book entitled, The Immigrant Invasion, contrasts the standard of life of the English-speaking laborer in the anthracite coal-mining region with that of the Slav and Italian laborer. The English-speaking laborers of the period before 1880 , he says-

wanted a home, with a wife and children and some degree of comfort. In that home he wanted none but his own immediate family or near relatives. For the rent of a neat, two-story frame house with a porch and yard he usually paid about four dollars a month. He wanted a carpet in the best room, pictures on the wall, and the home to be otherwise attractive and comfortable.... His wife he liked to see comfortably and fairly well dressed. For his children he had ambitions which required their attendance at the little red schoolhouse on the hill.... In brief, the standard of living 


\section{AN EXPERIMENT IN DEMOCRACY}

of the English-speaking races was a comparatively high one, which needed for its maintenance a comparatively high wage.

In striking contrast with all this is the mode of life which the Slav and Italian brought with them into the region. ... They came in batches, shipped by the car-load to the coal-fields. When they arrived they seemed perfectly aimless. It was hard for them to make themselves understood. They would land at the depot, and ... spend the first night on the platform, or in a stable on the hay.... Many were so poor that they came in old army suits, their belongings all in one big bundle.... These Slavs and Italians do not object to living in a one-room hut built by their own hands on the hillside, of driftwood gathered at spare moments from along the highway, and roofed with tin from discarded powder-cans. In not a few of their living-places the most conspicuous articles of furniture are bunks arranged in rows along the side of the wall. They are not particular with whom or how many they live, except that usually they want them to be of their own nationality. ... Out of a wage averaging the year round about thirty dollars a month many of the Slavs and Italians easily save from fifteen to twenty dollars a month. The Slav with a family cannot save so much, but in not a few cases even with a wife and children his slightly higher cost of living is met by the wife taking in "boarders." The family income is also increased through the work of the wife. ... She usually goes about barefooted and bareheaded even in the streets. . . Besides all this, to these workers children are an asset instead of a liability.

Under such conditions as these, in which the immigrants are concentrated in little com- 


\section{THE UNITED STATES}

pact communities around great industrial plants like the anthracite coal-mines and the Bethlehem steel-works, or in the slums of our great cities, the Americanization of the foreigner becomes increasingly difficult. He does not learn the English language, because he does not need to; he does not associate with Americans, because they do not live in his community; he feels no high regard for America because he soon learns that it gives him neither the opportunities nor the rewards which Americans have. A great number of these people come to America not to become Americans, but to save a little of their desperately earned money in order to return to the Old World. The children of those who do remain very likely learn English-after a fashion; but they too often learn English as an American in Germany learns German, not as a language which he intends to make his own, but as an instrument which may prove temporarily useful. In organizing the army under the selective draft it was found that in many of these foreign communities from 60 to 80 per cent. of the draftees could not speak English, and in many companies it was necessary to teach the men the simple words and phrases of the drill-book before undertaking to train them in the elementary movements of military tactics. They went to war to fight 256 


\section{AN EXPERIMENT IN DEMOCRACY}

for American ideals, often enough vaguely wondering what they were, or sullenly inquiring what benefits they promised to the exploited poor.

Mr. H. G. Wells, who is at all events a keen observer, has this to say in his book on The Future of America:

At present, if we disregard sentiment, if we deny the alleged necessity of gross flattery whenever one writes of America for Americans, and state the bare facts of the case, they amount to this: That America, in the urgent process of individualistic industrial development, in the feverish haste to get through with the material possibilities, is importing a large portion of the peasantry of central and eastern Europe, and converting it into a practically illiterate industrial proletariat. In doing this it is doing something that, however different in spirit, differs from the slave trade in its earlier history only in the narrower gap between employer and laborer. In the "colored" population America has already ten million descendants of unassimilated and perhaps unassimilable labor immigrants. ... And I have a foreboding that in the mixed flood of workers that pours into America by the million to-day, in the torrent of ignorance, against which that heroic being, the schoolmarm, battles at present all unaided by men, there is to be found the possibility of another dreadful separation of class and kind, a separation perhaps not so profound, but far more universal. One sees the possibility of a rich industrial and mercantile aristocracy of western European origin dominating a dark-haired, darker-eyed, uneducated proletariat from central and eastern Europe. 


\section{THE UNITED STATES}

This is the danger as Mr. Wells sees it. There is, no doubt, much exaggeration in the picture, if it is to be taken as a picture of America as a whole. Mr. Wells, besides being given to over-emphasis, sees that part of America which travelers mostly see-the Eastern part more than the Western, the cities and industrial centers more than the rural and agricultural communities. But this is just what the immigrant sees also, and the America which the immigrant sees is the whole of America for him. Whatever we may think, for the great mass of the foreign-born population America no longer stands, as it once stood, for the ideal of liberty and equality. When the immigrant thinks of America he thinks of New York with its palaces on Fifth Avenue and the massed squalor of its East Side slums; or else he thinks of the untold millions which our public-spirited billionaires have accumulated by the aid of men working twelve hours a day for wages that would barely keep a slave in sleek condition. When they think of America they think of the bloated bourgeois Republic; and so their minds, seeking for the everlasting ideal of democracy, seeking for the "right to life, liberty, and the pursuit of happiness," turn to bolshevism and the class war.

What Mr. Wells sees, and what the immi258 


\section{AN EXPERIMENT IN DEMOCRACY}

grant sees, is not the whole of America. The great heart of America, its humanity and idealism, its sanity and common sense, its attachment to the old conceptions of liberty and equal opportunity - these are to be found still (or will be, let us hope, when the unreason of the war frenzy shall have subsided) in the great mass of the people outside the large cities, in the quiet towns and villages and farming communities. What Mr. Wells and the immigrant see is not the whole of America. We must have faith to believe that it is not America at all. But at least it is a tendency in American life, and it is a tendency which must be recognized, and, being recognized, must be combated. If this is not so, then America, in any ideal or spiritual sense, and all she has meant for the world, will cease to be.

The problem of immigration is but part of a larger problem: it is part of the problem created by the disappearance of free land, by the rapid industrialization of America, and by the concentration of wealth and industrial power; it is part of the problem of industrial democracy - a problem which we, in company with the rest of the world, have yet to solve. That the United States-even the fortunate United States-must meet this problem has not escaped the penetrating eye of America's 


\section{THE UNITED STATES}

most competent as well as ner most friendly critic. In the latest edition of The American Commonwealth Lord Bryce has this to say:

There is a part of the Atlantic where the westwardspeeding steam-vessel always expects to encounter fogs. On the fourth or fifth day of the voyage while still in bright sunlight, one sees at a distance a long, low, dark-gray line across the bows, and is told that this is the first of the fog-banks which have to be traversed. Presently the vessel is upon the cloud, and rushes into its chilling embrace, not knowing what perils of icebergs may be shrouded within its encompassing gloom.

So America, in her swift onward progress, sees, looming on the horizon and now no longer distant, a time of mists and shadows, wherein dangers may be concealed whose form and magnitude she can scarcely yet conjecture. As she fills up her Western regions with inhabitants, she sees the time approach when all the best land ... will have been occupied, and when the land now under cultivation will have been so far exhausted as to yield scantier crops even to more expensive culture. Although transportation may also have become cheaper, the price of food will rise; farms will be less easily obtained and will need more capital to work them with profit; the struggle for existence will become more severe. And while the outlet which the West now provides for the overflow of the great cities will have become less available, the cities will have grown immensely more populous; pauperism ... may be more widely spread; and even if wages do not sink work may be less abundant. In fact, the chronic evils and problems of old societies and crowded countries, such as we see them to-day in Europe, will have reappeared in this new soil, while the demand of the 260 


\section{AN EXPERIMENT IN DEMOCRACY}

multitude to have a larger share in the nation's collective wealth may well have grown more insistent.

High economic authorities pronounce that the beginnings of this time of pressure lie not more than twenty years ahead.... It may be the time of trial for democratic institutions.

One may well contrast or compare this picture of the future of America, drawn by one of the most intelligent and one of the sanest minds of our age, as well as one of the best informed in all matters respecting America, with the picture drawn by Mr. Wells. The words are different, but the picture, although less highly colored, is much the same. Into this time of pressure described by $\mathrm{Mr}$. Bryce, the pressure created in every country which undergoes the industrial revolution, the United States is already passing. What dangers will we encounter? With what preparation, in intelligence and knowledge, in high courage and in civic virtue, will we meet them? 


\section{IX}

DEMOCRACY AND EDUCATION

I

W $\begin{gathered}\text { HEN we say, with easy confidence, that } \\ \text { the rapidity with which the immigrants }\end{gathered}$ are Americanized is due to our "institutions," we have in mind, among other things, the public schools. If it is pointed out that in many places the process of Americanization is slow and incomplete, or that it does not go on at all, we are likely to say, "The remedy for this is education." In America, while we have not too much respect for the educated, we have unlimited faith in education. Whatever ills democracy may be suffering from, the reply is always forthcoming, "The remedy for that is more and better education."

This attitude of mind is at bottom a sound one, in so far as it leads to a serious and intelligent interest in the schools - and it is not by any means confined to America. Wherever democracy exists, or wherever intelligent 262 


\section{AN EXPERIMENT IN DEMOCRACY}

people desire to have it exist, there the desirability of free education for the masses is likely to be insisted upon. The ruling class must be educated in some fashion; it may be badly educated, but at least it must have the sort of education that is suited to the kind of government that is in its keeping. If the ideal of government is an absolute monarchy, or a landowning aristocracy, or an ecclesiastical priesthood, or a combination of all three, then no doubt education should be confined to these classes. But if the idea that the people are to rule is frankly accepted, then it is obvious that the people should be as intelligent and well informed as possible; from which it follows that the state should provide free education for all its citizens.

This, at all events, is the theory which has accompanied the spread of democracy in Europe. Whereas in the Middle Ages and early modern period education was largely confined to the clergy, in the later modern period, and in proportion as the ideal of democracy has made headway, the State has replaced the Church in the control of education, and free public schools for the people have been widely established. Which was cause and which was effect in this process cannot be inquired into here; but, generally speaking, it is true that the ideal of popular education under the con- 


\section{THE UNITED STATES}

trol of the state is as commonly accepted now as the ideal of education controlled by and limited to the clergy was in the Middle Ages.

In this respect, as in respect to the idea of free government itself, the United States was in some measure a pioneer, and it has been in some measure an example to European countries. The quality and the smooth working of democracy in America have been commonly associated with the low percentage of illiteracy and the general diffusion of an elementary education among the people; and this happy situation, it has been assumed, is due to the existence everywhere, even in remote country districts, of the free public school. The United States has in fact been held up as a shining example of what a true democracy does in the way of educating its citizens, and of what an educated citizenship can do in the way of making democracy a success.

\section{II}

Serious concern for education was one of the chief characteristics of the Puritans who settled New England in the seventeenth century. The type of education which they wished to promote was indeed of a limited and very carefully guarded sort. Like all men who have a conscious and reasoned theory 


\section{AN EXPERIMENT IN DEMOCRACY}

of the ideal commonwealth, they wanted for their people an education which, by confirming the theory, would constitute a bulwark for the support and the preservation of the commonwealth; and as the Puritan Commonwealth was founded upon a definite theological creed and very precise notions of conduct, the schools which they established were devoted mainly to inculcating the accepted ideas of religion, politics, and morality. But at all events the Puritan desired that all children should learn to read and write, if only that they might read the Bible and copy its verses; and the novel and important aspect of his interest in education was that in order to accomplish these ends he adopted the practice of establishing schools in every community at the public expense.

In a community where the Church was a part of the State, the training of the clergy was obviously a matter of primary importance. Hence the Puritans had scarcely landed in Massachusetts Bay before they took steps to found a college for that purpose, and six years later Harvard College was in fact established. The existence of a college called for secondary schools. One of the earliest of these, and the first school in America to be supported by public taxation, was founded at Dorchester in 1639 . It was ordered by the 265 


\section{THE UNITED STATES}

town that twenty pounds be raised and "paid to such schoolmaster as shall undertake to teach English, Latin, and other tongues, also writing. The said schoolmaster to be chosen from time to time by the freemen." Within the first twenty years of Massachusetts history six grammar-schools had been founded in that colony.

But the founders of Massachusetts were not indifferent to primary-schools. Their ideal in this respect (it was not found possible to realize it fully) is clearly stated in the famous order of the General Court, issued in I647, which laid the foundation of the common school system in the province, and has been called the "mother of all our school laws."

It being one of the chief projects of that old deluder Satan to keep men from the knowledge of the Scriptures, as in former times by keeping them in an unknown tongue, so in these latter times by persuading from the use of tongues, ....

It is therefore resolved, That every Township in this jurisdiction, after the Lord hath increased them to the number of fifty householders, shall then forthwith appoint one within their Town to teach such children as shall resort to him to write and read, whose wages shall be paid either by the parents or masters of such children, or by the inhabitants in general ... as the major part ... shall appoint....

It is further ordered, That when any Town shall increase to the number of one hundred householders, 266 


\section{AN EXPERIMENT IN DEMOCRACY}

they shall set up a grammar school, the master thereof being able to instruct youth, so far as they may be fitted, for the university: Provided, that if any Town neglect the performance hereof above one year, that every such Town shall pay five pounds to the next school until they shall perform this order.

The Massachusetts school system, as actually established and as projected in this law, is in all essential respects the model upon which the school system of the United States has been fashioned. These essential points are, first, a free primary-school in every local community to teach the rudiments of knowledge to all children who may attend; second, a grammar-school (that is to say, a secondary, or, as we say, a "high" school) in every community to teach the elements of general culture and to fit youths for the university; and finally a college or university to train men for the professions or to give them a "liberal education." The Massachusetts law did not require either the primary or the secondary schools to be supported by public taxation, nor did it require the secondary schools to be "free" schools. But in practice, both in New England and later throughout the United States, both primary and secondary schools have come to be free and publicly supported. Harvard University has remained a privately endowed institution, and it still requires of 267 


\section{THE UNITED STATES}

its pupils the payment of high fees. In the East most universities, among them some of the best in the country, have followed Harvard in this respect; but in the region west of the Alleghanies the universities are commonly "state universities"- that is, they are integral parts of the system of free public schools, being supported by taxation and controlled by public authority.

The establishment of free schools was made an easy thing in America, as many things have been made easy, by the existence of an abundance of public land. From an early date the New England colonies took advantage of this fact by reserving, in the town grants, a certain part of the land as an endowment for schools. The example of New England became at a later date the settled practice in all the newer parts of the United States. In the Northwest Ordinance, passed by Congress in 1787 for the government of the territory north of the Ohio River, there was included the following clause: "Religion, morality, and knowledge being necessary to good government and the happiness of mankind, schools and the means of education shall forever be encouraged." The clause was not mandatory, but it has proved something more than a mere pious hope. In all the states formed out of the public domain the common 268 


\section{AN EXPERIMENT IN DEMOCRACY}

practice has been to make extensive reservations of lands as an endowment for public education. Such lands have indeed too often been badly administered, and in some cases largely diverted from their original purpose by political jobbery; but the existence of free schools in all the newer states, from the little "district" schools in every township, up through the graded grammar and high-schools in every county or urban community, to the state university, is due in no small measure to this practice of reserving public lands as an educational endowment.

That such reservations were so generally and so generously made for this purpose meant, of course, that the people who settled the West were themselves seriously interested in education. Few pioneer settlements, even the most primitive, were long without schools. The little log school-house was often the first public building erected, frequently serving the double purpose of religious worship and secular instruction; and, as the community grew, additional school-houses were built. The establishment of schools, in fact, kept pace with the progress of settlement, and by the middle of the nineteenth century free elementary education, supported by public taxation, had been established in practically every part of the country. 


\section{THE UNITED STATES}

When the pioneer used the word "education," he did not, of course, mean quite what the college professor means by it. The pioneer wanted his children to be "educated" in the sense that he wanted them not to be illiterate - he wanted them to be able to read, write, and "do arithmetic." He wanted them to be able to do these things even if he could not do them himself; in fact, if he could not read and write himself, he was likely to want particularly that his children should be able to read and write. The underlying motive which has given the people of the United States so keen an interest in "education" is indeed an essential part of their democratic habit of mind. No man takes it as a matter of course that his status is fixed, or that his children must necessarily be what he has been. It is rather a matter of course that a man's children may do something more and achieve something better than he has found possible. All that they need is a "better chance" than he has had; and it is, above all, "education" that will give them this better chance.

Nowhere has this feeling been more common or more intense than in the newer Western parts of the country, where the development of the community has been so rapid, where class divisions have been relatively non-existent, and where lack of training has been the 


\section{AN EXPERIMENT IN DEMOCRACY}

chief bar to individual advancement. In the frontier communities, therefore, the devotion to education was wide-spread, intense, and extremely practical in its object. Every one wanted the boys and girls to have a "better chance." All boys and girls must, as a matter of course, learn to read, to write, and to do sums. But in any community, as soon as that came to be a common achievement, so that to be illiterate was almost a disgrace, to be able to read and write and "do arithmetic" was not enough. If a boy was to have his "better chance" he must go to a "higher" school where he could learn to do arithmetic better than his father, and study algebra and grammar, which his father perhaps never studied, or perhaps learn a language, or read books which his father never heard of. To the father who never went to a "high-school" this was very wonderful-this was to "have a chance." But to the boy himself the highschool became in turn a matter of course; and for his boy, who must also have his better chance, nothing would serve but a collegethe boy must go to a university and become a "real scholar," so that he would have every opportunity that any man could have.

To the people of the United States, and particularly to the people of the newer regions of the Middle and Far West, where indeed the 


\section{THE UNITED STATES}

American system of public schools has received its most characteristic form, education has essentially always meant just this: That the boy, and the girl, too, must, if possible, learn something which their parents never knew in order that they might have a better chance to rise in the world than their parents had. It is this attitude of mind that largely explains the otherwise astonishing fact that the people of these Western states, the great majority of them relatively poor and uneducated, have been willing to pay taxes for the support of high-schools and universities. The number of boys and girls who ever go to the university, or even to the high-school, is very small in comparison with the total population. One might suppose that the average man would regard these higher schools as "aristocratic" institutions and be inclined to think that they should be supported by the people whose children took advantage of them. But the fact is that no one could be sure who was an "average man"; no one could be sure that his children would not be among the favored few; every man could at least have a reasonable hope that his children would graduate from the high-school at least, and perhaps (who could tell?) even from the university.

It is this reasonable hope that made people willing to support free higher as well as free 


\section{AN EXPERIMENT IN DEMOCRACY}

primary education. It is this reasonable hope that finds succinct expression in the constitution of the state of Indiana, which was drafted in 1819 , and which may be taken as representing the common practice:

It shall be the duty of the General Assembly, as soon as circumstances will permit, to provide by law for a general system of education ascending in regular graduation from township schools to state university, wherein tuition shall be gratis, and equally open to all.

In this spirit the Western States established their public schools. And to-day it is a rare country district which has not its little schoolhouse at the crossroads within easy walkingdistance of every home; a rare town which has not its graded grammar- and high-school; a rare state which has not within its borders at least one university and one or more colleges and academies; and almost all of the lower schools, as well as a great number of the universities, are free schools, are maintained by public taxation and controlled by the public authority.

The public-school system of the United States is rightly regarded as one of the most characteristic, as one of the essential parts of American democratic institutions. What kind of education do these schools furnish? How do they serve the purposes of democracy? 


\section{THE UNITED STATES}

\section{III}

The purpose of the public-school system is, after all, social rather than strictly intellectual. It is only in the college or the university, and sometimes not even in them, that a pupil can become "educated" in the academic sense. Only an insignificant part of the people ever see the inside of a college. In after-life it is difficult to distinguish the high-school graduate from one who never got beyond the grammar grade, or a university graduate from one who never got beyond the high-school. The public schools are in fact a socialistic enterprise on a grand scale; and the employment of some six hundred thousand teachers, and the expenditure of over half a billion dollars of public money annually in such an enterprise, can be justified only if the result is an advantage to the community as a whole rather than primarily to the individual concerned. In theory there is perhaps no necessary opposition between the advantage of the individual and that of the community. But there may be in practice; and since the advantage of the schools to the community can come only through the individuals who pass through them, it is and must remain a fundamental assumption that the chief purpose of free education in a democratic soci- 


\section{AN EXPERIMENT IN DEMOCRACY}

ety is to make good citizens rather than good scholars.

This primary purpose was long ago expressed, in the seventeenth century, by the Puritans of New Haven, who founded schools "for the better training up of youth in this town, that through God's blessing they may be fitted for public service hereafter, either in church or commonwealth." When, at a later time, the Church was no longer thought to be a necessary part of the State, the term "Church" was left out of this formula; but with that slight change the Puritan formula fitted nicely enough into the democratic political philosophy to which America has always held. That philosophy was formulated in the eighteenth century, and the idea of free schools, supported and controlled by the state, was an essential part of it.

Eighteenth-century political philosophy was fashioned mainly in France at a time when the progressive minds of the age found the welfare of men hampered by arbitrary government and by the outworn and senseless privileges enjoyed by nobles and clergy and monopolistic industrial corporations. They reasoned, therefore, that the wretched state of the great mass of the people was due, not to native viciousness, but to bad laws and customs. If you would make men better, more prosperous, and more 


\section{THE UNITED STATES}

happy, they said, you must first of all give them freedom; you must abolish arbitrary government and class privilege and, by conferring political and personal and industrial liberty, give every man a chance to make the most of himself. But this was not all. There would still remain certain inequalities. One man would be born intelligent, another stupid; one would have an excellent home-training, another would lack this training. These inequalities, arising from difference in capacity and from advantages of birth, it was the business of the state to remove as far as possible. According to eighteenth-century political philosophy, it was, therefore, the duty of the state to establish a system of free elementary schools, through which all citizens would pass, and which would mold them all to some degree of equality. A uniform education, it was hoped, would in time give to all citizens that common capacity and that similarity in civic virtue which would be the sure foundation of genuine democracy and of steady progress toward human perfectibility.

The generous expectations of eighteenthcentury philosophers have not been fully realized. Neither free government nor free public schools which have come with free government have brought about the reign of felicity 


\section{AN EXPERIMENT IN DEMOCRACY}

or the regeneration of the human race. But the modern faith in public education, so far as that faith still persists, rests upon the same general philosophy; and it is in the United States, where the philosophy was never so consciously elaborated as in France, that it has been most effectively confirmed in practice. Not in any ideal way, but in a practically effective way, the public schools in the United States do make for equality; they do in some measure enable men to enter upon the economic struggle for existence on more equal terms; they do in some measure tend to shape the mind and manners of men to a common social type; they do, most of all, bridge the gap between rich and poor, the well dressed and the shabby, the soft mannered and the brutal, by throwing them together at an impressionable age and forcing them to compete or co-operate in common tasks and common activities.

The most characteristic and the most important part of the public-school system is that which is comprised in the primary and grammar grades. These are the people's schools in the strict sense; for throughout the country these are almost the only elementary schools, and to these schools practically all the children go. In any typical community there is every reason for parents sending their chil- 


\section{THE UNITED STATES}

dren to the public schools, and, except perhaps in the case of strict Catholics, none for refusing or neglecting to do so. It costs them nothing -in some places even the text-books, paper, pencils, pens, and ink are furnished gratis. The hard-worked mother of a family often finds other than educational advantages in turning over her children to the safe guardianship of the schoolmistress from nine to four o'clock five days in the week. Besides, it is taken as a matter of course that a child shall "go to school" from the age of five, at least, until the age of twelve or fourteen. In any small community a family that does not send Jane and Tom to school is a marked familythe neighbors wish to know the reason, and if none is forthcoming they pity the children as unfortunates and condemn the parents as culpable.

To these schools, then, all the children of a community come, and there they learn-in a routine way, indeed-the essentials. They learn to add and subtract and divide, and to do fractions and compute interest. There they learn a little about the geography of the world, they learn to name the states of the Union, their capitals, chief towns and rivers, and their leading industries. They learn a little English grammar, are corrected when they say "I seen" or "he has went" (although very 


\section{AN EXPERIMENT IN DEMOCRACY}

rarely when they say "he don't"), and make some progress in writing, and in the mastery of the intricacies of English spelling. There they learn the elements of American history, and of the form and working of local and national government. They learn all this, and this is much for all the people to learn. It means that in any average town or country community it is a rare thing to meet any person who cannot sign his name to a subscription, or write a letter to a friend, read a newspaper, or a book out of the circulating library. It means that the great majority of the people know something about the countries of the world, and more about their own country, about its history, about its government, about its public men and political parties and the issues that divide them. For all the people to learn this means that all have that rudimentary knowledge which makes the effort to earn a living much easier than it would otherwise be, and that intelligent interest in general affairs without which democratic government would be impossible except in name.

It is important that all the people learn these things; it is quite as important that they learn them together and in the same way; for in learning them together and in the same way they learn a good many other things 


\section{THE UNITED STATES}

besides. The children of the poor and the rich, the cultured and the ignorant, the good and the bad, assemble in the same room and study the same books and recite the same lessons. Johnny, the banker's son, sits in the seat next to Jake, the butcher's boy, or Gertie, the washerwoman's daughter. In the freemasonry of youth they give each other the wink, or whisper out of hours, or exchange needed crayons or paper pads. There is, generally speaking, one rule for all, and Johnny is reprimanded for whispering, or Jake is commended for good behavior, without discrimination; or if by chance there seems any discrimination, "teacher" falls under the severe censure of all her pupils. The school-room is a juvenile democracy with a marked public opinion of its own which insists above all things upon impartial justice, silently withdraws its "mandate" from the instructor who has favorites, and ostracizes any pupil so lost to a sense of the social welfare as to become "teacher's pet."

The playground is even more democratic than the class-room. There is, in connection with the American public school, an important institution known as "recess"- an intermission of fifteen minutes in the middle of the morning and another in the middle of the afternoon session. During recess the children, 280 


\section{AN EXPERIMENT IN DEMOCRACY}

in pleasant weather, march out of the building, and when the ranks are broken pandemonium is let loose. For a moment the struggling mass of humanity is a howling mob; but it is a mob which, in true American fashion, quickly arranges itself in groups according to the interests or likings of the individuals composing it. Games of all sorts are immediately in course; and ordinarily, so far as boys are concerned, the worth of any boy and his standing among his fellows is largely determined by his ability to organize attractive games and his skill in playing them. Baseball is the American national game, and it is the publicschool playground that chiefly makes it so. It is the principal school sport. School-boys all know, and nearly all play, baseball; they take it with intense seriousness, and it furnishes an admirable test of strength and endurance, or accuracy, or sure judgment, and of self-restraint. But it does more than this. On the baseball-field of the public schools all the boys of a community, of high or low degree, good, bad, or indifferent, submit themselves voluntarily to a single test - the test of merit in playing the game. And when a "team" is organized to compete with a neighboring school, by common consent the best players are chosen. Nothing else counts. It might be a choice between the son of the 


\section{THE UNITED STATES}

President of the United States and a bootblack; only one question would be askedwhich can play the better? And the better player would be chosen. The chances are that it would be the bootblack.

This is, on the whole, the spirit which animates the boys in respect to their life in the public schools. They form an essentially democratic community in which all have to submit to the same standards of judgment. The judgment is essentially direct and fairminded, except perhaps in respect to the odd or unusual boy who happens also to be an incorrigibly unsocial boy. It is something of an ordeal for a new boy-a country boy, for example, entering a city school-to be subjected to the severe scrutiny and the roughand-ready tests which he cannot escape. For the attitude of the school-boy is not cosmopolitan; the outsider is a foreigner and an enemy, and until he is initiated and proves himself one of them his life is made a burden. School-boys are democratic only within the tested group. Toward outsiders they are, although very human, scarcely humane or engaging. The new boy is at once the observed of all observers; the center of frank and impertinent and brutal curiosity and criticism; the object of friendly insult and intolerable familiarity. He is simply being tested, as any 


\section{AN EXPERIMENT IN DEMOCRACY}

social group tests a new-comer; the only difference is that school-boys have no reticences, and they accomplish in three days what with their elders would take three months or three years. They want to see straight off how the new boy will take them and their manners. They want to get used to him in the shortest order. Above all, the new boy must not cry or sulk. Let him grin and stand up to it: let him return insult for insult, blow for blow, taunt for taunt, and it is soon over; he is accepted at once as a brother, and has henceforth an equal chance with every member of the community.

It is in the lower grades of the public schools that the work of Americanizing the foreignborn and the children of the foreign-born goes on, often with a thoroughness that leaves nothing to be desired. Mary Antin has written a fascinating account of her own Americanization, and of the notable part which the public schools played in it. She was indeed an exceptional child-too exceptional to be the basis of any generalization; but she speaks also for thousands of others upon whom the schools have had a similar transforming effect, but who were doubtless less conscious of the process, or who at least less consciously supervised and promoted it. It is not worth while, she says- 


\section{THE UNITED STATES}

to refer to voluminous school statistics to see just how many "green" pupils entered school last September, not knowing the days of the week in English, who next February will be declaiming patriotic verses in honor of George Washington and Abraham Lincoln, with a foreign accent, indeed, but with plenty of enthusiasm. It is enough to know that this hundredfold miracle is common to the schools in every part of the United States where immigrants are received.

The miracle is perhaps not often complete between September and February. Perhaps it is not even a miracle at all, but a very natural process of transformation, more or less independent of the "enthusiasm" of the pupil; but at least the transformation goes on, and it goes on much more rapidly in the schools than it does anywhere else.

Miracle or not, the transformation goes on in most cases, especially in the case of boys, more rapidly and more effectively on the playground than in the school-room. The little German or Italian boy is precisely in the position of a new-comer, except that an extraordinary curiosity attaches to him on account of the odd clothes, or manner, or habit of speech that is likely to make him a shining mark. All these peculiarities are noted, imitated in derision, and advertised as fit subjects for ridicule. The boy's name is of no importance; he belongs to a well-known species 284 


\section{AN EXPERIMENT IN DEMOCRACY}

- "Dutch" or "Dago," as the case may beand this little boy, whose parents are so fondly endeavoring to keep him in the way of speaking German or Italian, finds that his constant companions regard any "lingo" as reprehensible. The little boy does not like to be called "Dutch" or "Dago," and his one consuming ambition is to divest himself of every badge or trait, every shred of costume, every mannerism or tone of voice, which might distinguish him as "different" from the others. Hence he becomes an American with a swiftness that amazes his parents. The process which brings about this transformation is a bit brutal, but it is effective and enduring.

The high-schools and universities are essentially parts of the public-school system in fact, even if not always so in law. Instruction covers a different field of study and is more advanced and mature, but it is not essentially different in kind. The high-school pupil studies English language and literature, perhaps Latin or German, history and government and economics, a bit of botany, or physics, or possibly chemistry. In the university the same subjects, multiplied and specialized, are studied, under more competent masters and with added facilities and in greater freedom; but in method of instruction and in the tests applied, the transition from grammar grade to 285 


\section{THE UNITED STATES}

high-school, from high-school to university, is in no sense revolutionary. Above all, in the association of the pupils with one another, and in the various activities and "interests" which they pursue outside the class-room, the same spirit prevails and the same social influences are at work as in the grammar grades. The high-school and the university pupils play the same games, more systematically organized, more professionally, and, in the university, at least, in somewhat less of the spirit of the "career open to talent." To these activities the high-school and university pupils add other, more mature and more sophisticated, social activities-debating and literary clubs; literary periodicals and newspapers; class organizations with their elected officers, and the "politics" that inevitably accompany elections; "society" in the narrow sense, with its receptions, dances, informal "affairs," and the jealousies and aspirations and triumphs which attend these things.

The high-schools and universities, taken as a whole, are true reflections of American life. Learning has in them as much and as little prestige as it has outside. They do not make, and do not aim to make, "scholars" of their pupils, although the university opens the door to the scholarly life for those who seek it. Nor does the university make of its pupils a 


\section{AN EXPERIMENT IN DEMOCRACY}

distinct class in after-life. There is in both high-school and university a good deal of youthful' snobbery, but in general the experience is wholesome, and it tends to liberalize the mind and broaden the sympathy of its beneficiaries. The members of the higher schools are subjected to much the same tests, although in more subtle and urbane ways, as the members of the lower schools; in a wider field, they learn to co-operate or compete at common tasks with all sorts of people; they learn to detect the substance beneath the form, and to accord merit, in themselves and in others, to talent rather than to position.

It is a reflection, as well as a confirmation, of the democratic character of our society that poverty is no bar to a university career. In practically every college and university there is always a considerable number of students who pay their expenses by working during odd hours in term time or throughout the summer vacations. There are many colleges in which from 50 to 75 per cent. of the students pay their own way in whole or in part, a circumstance which is sure to strike the European observer of American institutions as singular, very likely as admirable, but at all events as "so American." M. Paul Bourget, in his book on America entitled, 


\section{THE UNITED STATES}

Outre-Mer, gives some specific instances that may be taken as typical.

I remember [he says] when I was in Newport being entirely nonplussed by the question of a negro who waited upon me in the hotel, a sort of black giant whom up to that time I had admired solely for his dexterity in carrying on the flat of his hand a tray loaded with six or seven entire dinners.

"Is it true, sir," he asked me, "that you are going to write a book about America?"

"Perhaps," I replied. "But why do you ask?"

"Because I should much like to have a copy to read this winter in college."

"The negroes are so vain," said a New Yorker, to whom I laughingly related this dialogue. "He wanted to make you think he knew how to read." . . . My witty interlocutor was mistaken. It was not in braggadocio that the waiter in the Newport hotel had spoken of his college. I had proof of this when ... I received a letter which I cannot refrain from setting down here in all its artlessness, so significant does it appear to me.

"I write you a few lines to let you know that I have succeeded in entering college as I hoped to do. I entered January I, and am getting along very nicely with my studies. My wish was to take the full, regular course, but I am not able to do so as I must support myself while in school. I must therefore content myself with the normal and scientific course. I do not precisely know what I shall do next summer. I have thought of going back to the hotel in Newport, but nothing is decided. I am looking for a copy of your book when it is finished." 


\section{AN EXPERIMENT IN DEMOCRACY}

What can be the spirit of a college on wnose benches a servant, twenty years old and more, may take his place for six months in the year, between two terms of service, and the fact not appear in the least exceptional?

M. Bourget relates the history of another student, in Harvard University, of whom he learned from Mr. Frank Bolles, the treasurer of the university. The statement is worth repeating, not because it is exceptional, but because it is so common that it would scarcely excite comment in any college or university in the United States.

The poor student fixed his freshman expenses at $\$ 38 \mathrm{r}$, his sophomore expenses at $\$ 36 \mathrm{r}$, those of his junior year at $\$ 395$, and those of his senior year at $\$ 462$. He had $\$ 25$ of debts when he entered Harvard. He was, therefore, obliged to earn money, and a large sum of money, during these four years, while at the same time pursuing his studies.

The details of the methods he pursued are very significant. As freshman, he "made" $\$ 346$, thus divided: a prize of $\$ 250$, a loan of $\$ 15$ on his watch, $\$ 71$ earned by typewriting for his fellow-students, $\$ 8$ by selling books, $\$ 2$ by tutoring.

As sophomore he used the same methods, except that in view of the smallness of the prize gained that year, he decided to wait at table. His work as waiter brought him \$38. It may be remarked that this is not an isolated case. Many Harvard students gain by this means, especially during vacations, the small overplus of resources they require. This student, in his second year, added to this business that of preparing the brains 


\section{THE UNITED STATES}

of sheep for the lectures of Prof. William James, the great psychologist.

The third year-the junior-appears to have been easier. Tutoring brought him in more-\$12O. He got work in the library that helped to set him on his feet. A large prize which he took in the fourth year put an end to his difficulties, and he left college at the completion of his studies, having met all his expenses during the four years and put aside a small sum of money.

This is a perfect specimen of the American student, and $\mathrm{Mr}$. Bolles is right in concluding at the close of his letter, "A young man who has gone through this is certain to succeed in any calling." He cites among possible careers railway service, journalism, bookpublishing, political life, and teaching. The elasticity of this program is simply in conformity with the genius of a country where a man finds it perfectly natural to change his profession at forty, fifty, or sixty years. One consequence of this facility of guiding his life in the most opposite directions is that the "poor scholar" is unknown in the United States. The students who wait upon their classmates, napkin on arm and dish in hand, and who will presently be sitting on the same benches with them, attending the same lectures and passing the same examinations, have, if one may so speak, taken and given a lesson of destiny. They know and they demonstrate that the man of energy accepts all and conquers all, if only he will. Neither he nor his fellow-students will forget the lesson.

This is all very true and very admirable. The young man whose career $M$. Bourget describes was an excellent young man, and the training which he received was an excel- 


\section{AN EXPERIMENT IN DEMOCRACY}

lent training for almost any kind of endeavor in after-life; but it is obvious that a young man with so much seriousness and energy would have been able to achieve a great deal more in a purely intellectual way if he had not been so heavily handicapped by the necessity of earning his own living. And the result, in colleges where there are so many serious and able young men who are handicapped in this way, is that the standards of scholarship maintained for obtaining the degree are somewhat lowered in order that the impossible may not be required of such students. It is a rare college or university in the United States in which an intelligent student who does not have to earn his living may not pass the examinations successfully without any very concentrated or continued mental effort. The presence of a large number of selfsupporting students is not the only reason for this, but it is one of the reasons, and one of the most difficult to deal with practically.

The standards for the degree are, of course, only a minimum requirement, and they are no measure of the quality of the universities. Particularly in the better universities, any student who has the time, the desire, and the ability may obtain intellectual training of a high order. Twenty-five years ago so com- 


\section{THE UNITED STATES}

petent a judge as Mr. Bryce gave his deliberate opinion on this point:

The higher learning [in the United States] is in no danger. The great universities of the East, as well as one or two in the West, are already beginning to rival the ancient universities of Europe. ... An Englishman who visits America can never feel sure how far his judgment has been affected by the warmth of the welcome he receives. But if I may venture to state the impression which the American universities have made on me, I will say that while of all the institutions of the country they are those of which Americans speak most modestly, and indeed deprecatingly, they are those which seem to be at this moment making the swiftest progress and to have the brightest promise for the future. They are supplying exactly those things which European critics have hitherto found lacking to America: and they are contributing to her political as well as to her contemplative life elements of inestimable worth.

This is no doubt true, and it is no doubt as true now as it was twenty-five years ago, although university faculties themselves complain of the decline of scholarship both among the students and among the instructors. It is no doubt a part of the business of faculties to complain of the decline of scholarship, and there is at least little evidence that productive scholarship is at a lower level now than formerly. But of course when one speaks of the "higher learning" and productive scholarship 


\section{AN EXPERIMENT IN DEMOCRACY}

in our universities, or in any universities, one has in mind a relatively small part of universities as a whole. At least, this is true in respect to American universities. Apart from our best graduate schools, the greater part of our universities, what we call our undergraduate colleges, have little to do with productive scholarship or the "higher learning." They are essentially schools devoted to furnishing students the elements of "general culture"; they are in fact scarcely more than extensions of the high-schools, and as such they are significant in a social rather than in an intellectual way; they are significant in reflecting and confirming American life rather than in adding to it. Both in high-school and university the pupils receive instruction from their teachers, and good instruction it often is; but essentially the pupils educate themselves by playing on a miniature stage the drama of American life. In playing this drama they acquire a keener sense of its meaning, a more conscious feeling for its spirit and its possibilities. An American boy may easily go through the public schools from the primary grade to the end of the college course without acquiring much knowledge of books, or any taste for the things of the mind, or any capacity for handling ideas; but he cannot do so easily without meeting all sorts of people, without finding 


\section{THE UNITED STATES}

his level among these people, without being subjected to tests which ignore his pet egoisms and his carefully nourished illusions, without learning that poverty is not a disgrace nor good manners a sign of weakness, without becoming in some measure aware of that essentially democratic truth that the merit of a man is independent of the externals which distinguish him, and of the accidents which place him high or low in the social scale.

This has been well enough in the past, but it is doubtful whether it will continue to be so in the future; and it is a significant fact that our school system, from top to bottom, is just now under rather general and drastic criticism. So long as American life is essentially democratic, as it has been in the past, the public schools, even if they do no more than to reflect and confirm that life, must have a powerful democratic influence. But if, as there are many indications, and as many people are coming to think, American life is becoming less democratic than it was-if class divisions are becoming more marked and more permanent, if political freedom is becoming ineffective because economic freedom is disappearing, if plutocracy is becoming the substance and democracy only the form of American societyif this is what the future holds, then the public schools can no longer serve democracy to any 


\section{AN EXPERIMENT IN DEMOCRACY}

purpose by merely reflecting and confirming the conditions of life. Their task, in that case, is to work against these conditions. This, in a general way, is the task of the public schools for the future; and in order to accomplish this task they must be informed by a more conscious and deliberate purpose than they have been; they must devote themselves with better talent and greater concentration to things intellectual; they must lead and not follow the best thought of the age, shape and not be shaped by the pressure of economic and social tendencies. This will be no slight undertaking, but it will be no more difficult than democracy itself, of which, indeed, it will be an essential condition. 


\section{$\mathrm{X}$ \\ DEMOCRACY AND EQUALITY}

SINCE the French Revolution liberty and $S$ equality have been words to conjure with, perhaps because their meaning is not capable of very precise definition. They are commonly used together, as though they were but different aspects of the same thing; but many people find, upon analysis, that they mean precisely opposite things. Men cannot be made equal, they say, without being subject to a great deal of restraint, for perfect equality would mean that no man could be permitted to have what any other man could not have, or to do what any other man could not do. On the other hand, it is maintained, a man cannot be perfectly free unless he is allowed to do as he likes. According to these people, therefore, the desire for liberty is contrary to the desire for equality, so that if liberty is what men want they ought to renounce the idea of 296 


\section{AN EXPERIMENT IN DEMOCRACY}

equality, and if equality is what they want they ought to renounce the idea of liberty.

The men who inaugurated the French Revolution evidently did not think that this was true, since they desired and demanded both liberty and equality, not to speak of fraternity in addition. In their famous "Declaration of the Rights of Man and the Citizen" they proclaimed that "all men are born free and equal in rights"; and they were so far from thinking that liberty and equality were inconsistent with each other that they defined them in the same phrase. "Liberty," they said, "consists in the freedom to do everything which injures no one else; hence the exercise of the natural rights of each man has no limits except those which assure to the other members of society the enjoyment of the same rights." This is perfectly clear as a principle, although the application of the principle may not be very easy. By this definition liberty does not mean the right of a man to do as he pleases, but only the right to do as he pleases in so far as he does not please to interfere with the equal right of every other man. The emphasis is chiefly on equality, for liberty is defined in terms of equality; and M. Émile Faguet has written a brilliant essay to prove that to the men of the Revolution liberty and equality meant the 


\section{THE UNITED STATES}

same thing; that what they chiefly wanted was equality, and that they believed that if men had equality they would thereby have all the liberty they needed or were likely to want.

M. Faguet is doubtless right. But even if the men of the Revolution had their minds fixed primarily upon equality, they expected to get it not so much by imposing restraints as by removing them. They found themselves living in a world where the most glaring inequalities existed; but these inequalities were sanctioned by laws and customs which restrained one man from doing what another man was permitted to do. The peasant or the noble was forbidden to do what the member of the industrial gild could do; the gildsman was forbidden to do what the noble could do; and every man was forbidden or required to do whatever the king might take it into his head to command. The men of the Revolution were, therefore, convinced that the glaring inequalities that existed were due to the fact that a man's liberty of action was thwarted and restrained at every turn by quite senseless restraints. It was for this reason that they saw liberty and equality as two parts of the same thing. They easily 


\section{AN EXPERIMENT IN DEMOCRACY}

supposed that if the existing restraints upon liberty of action were removed, the existing inequalities in conditions between classes and individuals would largely disappear. Thus they expected to get equality of conditions by the simple process of removing the legal restraints upon liberty of action.

In carrying out this program there were three kinds of liberty which they wished to establish: personal liberty, industrial liberty, and political liberty. By personal liberty they meant that no man should be bound to any other contrary to his will, nor subject to arbitrary arrest and imprisonment by the government; and in addition they meant that every man should be free to speak and publish his opinions. By industrial liberty they meant that every man should have the right to engage in any legitimate occupation, the right to sell his labor by a free contract, the right to buy or sell commodities unhampered by legally established restrictions or privileges. By political liberty they meant the abolition of arbitrary government, the establishment of a government controlled by the governed and acting only on the sanction of laws which should be the same for all.

The men of the Revolution believed that if they established these liberties the desired equality would thereby, automatically, as it 


\section{THE UNITED STATES}

were, be attained. They reasoned that if political liberty existed the laws would be equitable, because the people who made the laws would be the very people who had to submit to them. This result would be further guaranteed by that freedom of thought which, by enabling every man to declare his interest and express his opinion, would enable the people to know what laws were just and equitable. Above all, they reasoned that industrial liberty would result in a reasonable degree of economic equality; for if every man was free to engage in any occupation, to sell his labor, or the products of his labor, where he could get the most for them, and to buy what he needed where he could get it at the lowest price, why, then, generally speaking, one man would have as good a chance as another and each man's share in the common wealth would be determined largely by his own efforts. Men would no doubt differ in ability; but it was supposed that with a system of free elementary education any man of reasonable intelligence and industry might acquire the skill and practise the frugality which would enable him to support himself and his family in comfort and content.

The men who formulated the philosophy of the Revolution were mainly of the middle class; and in its earlier and later stages the 


\section{AN EXPERIMENT IN DEMOCRACY}

Revolution was mainly directed by this class -it was what is called a bourgeois movement. To these people the idea of achieving equality through the removal of restraints upon liberty was entirely satisfactory, and to them it remained so long after the lower classes found it entirely unsatisfactory; they felt that if they had enough freedom of action they could take care of themselves, and they easily persuaded themselves that the peasants and working-men would be much better off than they had been. The peasants, in France at least, certainly were a good deal better off because they came into full ownership of their land, and the taxes which they paid to the state after the Revolution were very much less than the taxes and feudal dues which they paid before. But on the whole, it must be said that the liberties which the Revolution brought with it were chiefly advantageous to the bourgeoisie. The political freedom which it established, although based upon the doctrine of popular sovereignty, placed the government in the hands of the educated people and the owners of property; the freedom of opinion and of the press for a long time in France meant scarcely more than the freedom to express such opinions as respectable middle-class people were not afraid of; the industrial freedom which followed the abolition of the old medi- 


\section{THE UNITED STATES}

eval gilds and trade corporations was an advantage to the men with capital, but proved in the end disastrous to the laborer. The "liberty" established by the Revolution was indeed mainly a bourgeois affair; and so far from working automatically to bring about an ideal "equality," it only brought about an equality between the middle and upper classes.

In no respect did the revolutionary theory of liberty and equality break down so completely as in the field of industrial activity. The revolutionary leaders were so impressed with the desirability of complete economic freedom that they not only destroyed the old legally established gilds and close corporations, but they attempted to prevent the formation of private and voluntary co-operative industrial organizations. They were so determined to make every man economically free that when the working-men of Paris formed a kind of union in order to fix a minimum wage, and organized a strike to enforce such a wage, and attempted to prevent other workers from working for a lower wage, a law was passed forbidding citizens engaged in any industry or trade to form any organization whatever for the regulation of their common interests. This was done on the theory that every man must be free to sell his labor or his commodities to the highest bidder. Every 302 


\section{AN EXPERIMENT IN DEMOCRACY}

man must be free, whether he wanted to or not, because a man who was subjected even to the self-imposed restraints of a labor-union would not be in a position of equality with a man who was not subject to such restraints.

For over half a century the revolutionary theory that complete freedom of contract in the industrial field would bring about the greatest degree of economic prosperity for all men, the theory of laissez-faire, was the prevailing theory, at least among the ruling classes. Everywhere it failed. Everywhere, sooner or later, it brought about a glaring inequality of wealth. In every country, although not with the same rapidity, it brought about the concentration of wealth and economic power, and therefore of political power also, in the hands of great capitalists, bankers, manufacturers, and landowners, while the mass of the agricultural population remained poor, and the laborers in the industrial centers were reduced to conditions of life which the term "wage-slaves" graphically and accurately described.

This result of the revolutionary theory was nowhere so soon or so obviously worked out as in England; and the reason for that was that the industrial revolution, which was the most important economic phenomenon of the nineteenth century, began first and pro- 


\section{THE UNITED STATES}

gressed most rapidly in that country. The fact is that the revolutionary theory, on its economic side, suited only to society with a rudimentary industrial life, has broken down, and it is bound to break down in every country where industrial life becomes complex, and in proportion to such complexity. In Europe it has therefore broken down in every country in proportion to the development of what is called the industrial revolution.

The basis of the industrial revolution is the increasing application of material forces to the production of wealth. Technical inventions, the use of steam and electrical power, have transformed the processes of the production and the transportation of wealth, and have thereby vitally affected the distribution of it. The use of machinery makes it possible to multiply ten, a hundred, a thousandfold, the results of one man's labor. But to get the most out of machinery it is necessary to carry on industrial operations on a large scale, and this means that industry must be concentrated at particular points, and it means, above all, that the production and transportation of wealth cannot be carried on profitably without the use of a great deal of wealth to begin with, in the form of "capital." Under the conditions brought about by the industrial revolution 


\section{AN EXPERIMENT IN DEMOCRACY}

capital was, above all, necessary; and accordingly the possession of great wealth meant something more than that its possessor could live in a better house and eat better food and have better clothes and a better time generally than a poor man; it meant that by means of his wealth-by investing his capital in great industrial enterprises - he could take to himself all that multiplied power which was stored up in the steam and electricity and the technical machines through which alone the production and transportation of commodities could be most profitably carried on.

Under these conditions, to say that every man should be free to sell his labor, or the products of his labor, to the highest bidder sounds much like some huge Rabelaisian pleasantry. The poor man could only sell his labor and not the product of it; whereas the rich man could sell his labor, plus the product of his capital in the form of machine labor, plus the product of the labor of the men whom his capital employed to work his machines for him. This would not have been so inequitable if the laborer could have obtained in wages the real share of the product which his labor produced. But this he could not do because, on account of the unlimited expansion of machine power in production, there was never, or rarely, more capital than could be 


\section{THE UNITED STATES}

profitably employed, while there were always, or nearly always, more laborers than were needed, since the use of machines reduced relatively the number of laborers required and at the same time, through the employment of women and children, increased the number of laborers available. The result was that the individual laborer, who had to work or starve, had to sell his labor for what the capitalist would pay for it rather than for what it produced.

Thus the liberty which the Revolution established in the industrial world meant that "to him that hath shall be given, and to him that hath not shall be taken away even that which he hath." It meant, for the laborer, the liberty to sell his labor for a bare existence, if happily there was any one who would buy it at any price; and it meant, for the capitalist, the liberty to sell his own labor (if indeed he cared to work at all), plus the labor of as many men and as many machines as his capital represented. The result has been, throughout the nineteenth century, the increasing concentration of wealth and of the industrial power which it represents in the hands of a small class, and the increasing power of this small class over the production and distribution of wealth, and therefore over the lives, the fortunes, and the happiness of 


\section{AN EXPERIMENT IN DEMOCRACY}

all. In the economic sense, there is for the great mass of men and women neither liberty nor equality. Without a much greater degree of both than now exists, the personal and political liberties which have been so hardly won through a century of struggle lose half their importance, and democracy itself is scarcely more than a pious hope.

\section{III}

In no country was the eighteenth-century philosophy of liberty and equality so confidently, or perhaps so unconsciously, accepted as in the United States; to no country was it so well suited; in no country had it (until recently) worked so well or been so long unquestioned.

There are many reasons why this should have been so. The United States was, relatively speaking, accustomed to free government, free speech, freedom of religion, and freedom of contract from the earliest days of its history. No violent revolution was required, as in France, to establish these principles in practice, and the principles themselves never had to win their way against powerful and persistent traditions of a different régime. But above all, the eighteenthcentury philosophy of liberty was not incon- 


\section{THE UNITED STATES}

sistent with the existence of essential equality. In its origin the United States was almost exclusively an agricultural community, and until the last quarter of the nineteenth century it has never developed more than a rudimentary industrial life. The reason for this was, of course, the lack of capital at low rates of interest, and an abundance of good land at very low prices. No industrial laborer was likely to work for starvation wages so long as he could go West and become the owner of one hundred and sixty acres of land for the trouble of improving it. So long as any man could readily become a landowner, a highly complex industrial life could not easily be developed, and it remained true that the existence of political, personal, and industrial liberty did bring about, more or less automatically, an exceptional degree of equality.

The conditions which so long existed in the United States not only brought about a fair degree of equality among individuals, but they. prevented the formation of any defined or persistent class inequalities. Any individual could consent with some cheerfulness to be poor to-day, since there was always an even chance that to-morrow he would be "well fixed." The son of a laborer could without undue optimism look forward to becoming an employer; the son of a farmer was never des- 


\section{AN EXPERIMENT IN DEMOCRACY}

tined to follow the plow, but might reasonably aspire to the high dignity of a college professorship. In a country where changes in fortune and social status were so rapid and so common the people inevitably acquired a spirit of buoyant optimism which discounted such inequalities as existed; if they had not equality they projected it into the immediate future, and in that future, rather than in the present, they lived their lives. The tragedy in the life of Mr. J. M. Barrie's Admirable Crichton, says Mr. Herbert Croly-

was not due to any prohibition of his conversion in England, as on the tropic island, into a veritable chief, but that on English soil he did not in his own soul want any such elevation and distinction. His very loyalty to the forms and fabrics of English life kept him fatuously content with the mean truckling and meaner domineering of his position as butler. On the other hand, the loyalty of the American to the American idea would tend to make him aggressive and selfconfident. Our democratic prohibition of any but occasional social distinctions and our democratic dislike to any suggestion of authentic social inferiority have contributed as essentially to the fluid and elastic substance of American life as have its abundant and accessible economic opportunities.

Thus it is that for a hundred years, thanks to an abundnace of land, a settled democratic habit of mind, and a people in whom resource309 


\section{THE UNITED STATES}

fulness and self-confidence have come to be almost acquired characteristics, the United States preserved an equality of opportunity and of conditions quite unknown in Europe. It is no wonder, therefore, that the United. States still preserves a naïve faith in the political philosophy of the eighteenth century, whereas in Europe it has long since been. abandoned by most forward-looking men. The average American still believes that our equality is the automatic result of our liberty; he still believes that the high average of wellbeing in the United States is the result of free government and the superior character of its people; he still believes that the theory of "supply and demand" is a beautiful doctrine, that there is a kind of magic in the word "competition," and that "individual initiative" is one of the natural rights referred to in the Declaration of Independence; he still believes that the interest of each and the welfare of all will continue to be realized in the future as in the past by applying the good old rule of "every man for himself and the devil take the hindmost." Whoever is hindmost, he thinks, is so by his own fault; he has failed to take advantage of the opportunities which every American has.

The truth is, of course, that it is not our free government, but our fortunate economic situ- 


\section{AN EXPERIMENT IN DEMOCRACY}

ation, that has hitherto been the solid basis of our equality; and this fortunate situation is unhappily rapidly passing away. The close of the nineteenth century marks the close of an era. It was the period, on the one hand, when the great areas of fertile and accessible land were occupied; on the other hand, it was the period when the United States began to develop with amazing rapidity a concentrated and complex industrial life. What this transition means should be fairly obvious, for it is one of the many advantages of the United States that it may, if it will, profit by the experience of European countries. The industrial revolution has long been an accomplished fact in many parts of the Old World. The transformation in economic and social conditions which it brings in its train, the problems which it sets for solution, the solutions which have been attempted and which have failed or been in part successful, are all there revealed as in an open book. The obvious fact of our generation is that the United States is rapidly passing through the earlier stages of the industrial revolution, and that it must expect to be confronted with the same conditions, however more slowly developed or in whatever less acute form, which have appeared in those countries where it has occurred. 


\section{THE UNITED STATES}

As yet the United States is far from being as highly industrialized as England or Belgium or many other European countries; but the significant fact is the rapidity with which it is becoming so. Within a generation it has acquired the unenviable reputation, which many people fatuously take to be a mark of virtue, of being pre-eminently the land of gigantic trusts and combinations, the country of millionaires, the country blessed with the "richest man in the world." In fact, the United States is now known abroad less for being the land of liberty than for being the land of "big business," and of financial operations of a boldness and reach never before dreamed of; and within twenty-five years, although still one of the greatest agricultural countries, the growth of great cities and the rapid industrialization of certain regions have been so marked that books have been written to prove that within no great time New York will replace London as the commercial and financial center of the world's exchanges.

Industrial development was, of course, bound to come in the United States in proportion as the best lands were taken, as the country became relatively populated, and as capital increased and interest declined. The natural resources of the country, in the way of forests, coal and iron deposits, and other 


\section{AN EXPERIMENT IN DEMOCRACY}

essential raw materials, were such that no other result was possible or desirable. And this inevitable trend of development was deliberately fostered by the government. From an early date the federal government adopted the policy of aiding in the construction of highways; and the states and cities have granted untold wealth to corporations in the form of land and franchises in order to induce them to construct railroads and street-car lines, and to supply gas, electricity, water, and telegraph and telephone service. Above all, the federal government, during the greater part of our history since 1816 , has adopted the policy of high tariffs for the avowed purpose of protecting American manufactures from European competition. "Infant industries," it was argued, needed the paternal and fostering care of the government if they were ever to grow to maturity; and the giant stature which many of these "infants" have attained in recent years is due quite as much to governmental aid as it is to the "intelligence and initiative of the American business man." This policy of extending governmental aid in the industrial development of the country has been so extensively and persistently followed that from an early date it came to be known as "the American system"; and the American system was designed to do for 


\section{THE UNITED STATES}

industry much what the public land policy did for agriculture.

Never was the American system so extensively practised as after the Civil War; and never were the conditions so favorable for the development of "big business." The people turned with a sigh of relief from the high tension of the slavery controversy and the taut emotional enthusiasm of the war to the prosaic business of attending to their own affairs. American history records no era more materially minded than the twenty-five years from 1865 to I890. The South was ruined, and the one immediate task was the reorganization of its social system and the rehabilitation of its economic life. For a generation the North likewise, but with greater energy, became absorbed in the enticing game of exploiting the material resources of the country. The average man felt that, havings uppressed the Rebellion and abolished slavery, he had done a good job and could no longer be expected to be his brother's keeper.

Politics reflected the inevitable reaction from the idealism of the war. The defeat of the South, and the discredit which that defeat placed upon the Democratic party, left the Presidency and the Senate, at least, if not the House of Representatives, for the 


\section{AN EXPERIMENT IN DEMOCRACY}

most part in the undisputed control of the Northern Republicans. Politics still turned on the dead issues of the Civil War; and a passionate denunciation of the "rebellion," of the Southern "traitors" who had led it and the Northern "copperheads" who had abbetted it, was a sufficient qualification to elect any candidate to high office. In this era of public apathy, of sordid politics, and of mediocre statesmen, the industrial brigand tied himself to the dominant party and was given a free field. The unlovely history of many a "big business," builded upon special privilege and political corruption and the cynical wrecking of small business enterprise, was all too common in the last quarter of the nineteenth century; and when the public conscience began to stir in the 'nineties it was confronted with the amazing fact that in this land of democracy and equal opportunity a large proportion of the wealth of the country was in the hands of a relatively small part of the population, and that an industrial and financial mechanism had been constructed through which the magnates of business could exercise a dangerous influence upon the lives and fortunes of the people.

For many years the people had watched with complacent satisfaction the marvelous development of big business. They con- 


\section{THE UNITED STATES}

gratulated themselves and the country on the admirable results of "individual initiative," and exhibited an attitude of indifference, or even of hostility, toward the efforts of the industrial workers to obtain, through unions and by means of strikes, a fair wage and decent conditions of living. They said that these were "un-American" methods; attempts to restrict the freedom of the individual to work for whom he pleased, and under such conditions as he might choose; and they were rather pleased than otherwise when the great corporations, no doubt in order to preserve a free field for "individual initiative," employed private detectives and private military forces to break up the strikes and destroy the effectiveness of labor-unions.

But in recent years the public has come, or must one say only that it is coming, to take a different attitude. From about 1890 prices began to rise, and they have been continually rising since; so that while every one who has anything to sell gets more for it, the cost of everything he has to buy is so much greater that his position is likely to be no better than it was. The farmer gets a price for his wheat and corn which he never would have dreamed of getting twenty-five years ago; but the price of land and of machinery is so high that the renter finds it difficult to make a living 


\section{AN EXPERIMENT IN DEMOCRACY}

and almost out of the question to buy a farm. Small business men throughout the country find themselves in much the same position. For the mass of the people our boasted "prosperity" is largely fictitious prosperity. Meanwhile "big business" thrives as never before; the number of millionaires increases, while the chance of the average man's ever becoming one declines. Under these conditions the average man is more and more inclined to think that free competition and individual initiative are not perhaps among the inherent rights of man; he begins to think that somehow those on the "inside," by mysterious financial operations, by juggling the "market," by control of the press, and by means of political connections, are able to determine the prices of essential commodities. Under these circumstances a spirit of social unrest is arising. Everything seems not well in God's country; and many people besides the industrial laborer are seriously inquiring whether the beneficent principle of "individual initiative" is not, after all, only another name for "maintaining a private paternalistic regulation of other men's affairs." In the United States the trend of thought is turning at last, - as it has long since turned in Europe, from the question of the production of wealth to the question of its distribution. The problem of 


\section{THE UNITED STATES}

an equitable distribution of wealth is indeed a vital problem of the age. How can it be solved satisfactorily? Does its solution imply any radical modification of our political ideas, any fundamental changes in the form and characters of our government?

\section{IV}

In the latter part of November, I918, a successful lawyer, standing in the lobby of a Washington club, having lighted a fragrant Havana cigar, was heard to proclaim that it was of vital importance that the government should immediately restore the railroads, telegraph lines, and express companies to private hands, and surrender the control over industry and labor which it had exercised (rightly no doubt) during the emergency of the war. "I am opposed," he said, "to every interference with private initiative. Interference with private initiative is a socialistic doctrine, and it is contrary to the spirit of this government." This was a way the gentleman took of saying that he was opposed to governmental regulation of business, and of justifying that opposition by a finesounding, idealistic phrase. There are plenty of Americans who would applaud both the sentiment and the phrase, but one wonders 


\section{AN EXPERIMENT IN DEMOCRACY}

whether such people have ever seriously asked themselves what, after all, is the "spirit of this government."

If questioned they would probably say that the spirit of this government is one that makes for freedom and democracy, and that freedom and democracy have been achieved by giving the greatest amount of liberty to the individual and by the resolute refusal of the government to engage in any "socialistic" practices. No one would wish to deny that the "spirit of this government" is essentially favorable to liberty and democracy. What Americans pride themselves upon, and on the whole with good reason, is precisely that the United States has always been a shining example of applied democracy. But democracy means nothing, and has meant nothing, in the United States if it does not mean equality - not indeed a mechanical and deadening equality of goods and of conditions and of ideas, but a reasonable degree of equality of opportunity and well-being. The "spirit of this government" must, it would seem, be favorable to such equality, and to such measures as will effectively realize it.

Those who are more concerned for the rights of property than for the rights of men are inclined to make much of the distinction between what they call the "principle" of 


\section{THE UNITED STATES}

Individualism and the "principle" of Collectivism - between a political philosophy which denies and one which commends governmental restriction of individual liberty. This is a lawyer's doctrinaire distinction which corresponds to no essential reality. All government is an interference with individual liberty; without governmental intervention private property as we know-it would cease to exist. Governments have always assumed the right to determine what a man may and what he may not do with his property. In some countries and in some periods the restraints upon the use of property have been less in extent, or inspired by a different purpose, than in others; but whatever the restraints may have been, they have always been ostensibly justified on grounds of expediency. It is beating the air to discuss whether government should regulate private property; private property is the very essence of governmental regulation - the most fundamental and far-reaching of all the regulations upon which modern society is founded. The question which a sensible man will ask himself is, therefore, this: under the conditions of life as we find them to-day, what objects should we have in mind to guide us in the regulation of the use of private property, and what sort of regulations will prove best adapted to 


\section{AN EXPERIMENT IN DEMOCRACY}

attain that object? No questions are answered and no difficulties solved by saying that this kind of regulation accords with the "principle of Individualism," while that kind of regulation accords with the "principle of Socialism."

Moreover, the government of the United States appears never to have had much respect for the "principle of Individualism." It has never hesitated to restrain the "private initiative" of some men along some lines, in order to aid the "private initiative" of other men along other lines. Both the federal and the state governments have constantly occupied themselves, on a grand scale, with schemes designed to furnish citizens with opportunities which they would never have had if they had been left to rely wholly upon the blessed principle of Individualism. What was the public-land policy of the federal government, by which millions of acres of the public domain ( $p$ ublic land, be it noted) were virtually given away to the poor and needywhat was this but a "socialistic" enterprise? Is it "private initiative" that has lowered the percentage of illiteracy and raised the general level of intelligence in the United States? Or is this result due in great part to governmental intervention, in the form of taxes laid upon private property in order that every in- 


\section{THE UNITED STATES}

dividual, poor and rich alike, may have a common education free of cost to himself? Was the private initiative of our great "captains of industry" entirely responsible for their amazing success, or did they owe something to governmental aid, in the form of franchises, protective tariffs, and special laws advantageous chiefly to corporations? Our "infant industries," whose gigantic stature now amazes the world, still clamor, do they. not, for governmental intervention. It seems, in fact, that the only people who just now seriously oppose governmental intervention are the brewers. According to the philosophy of big business in general, one is forced to the conclusion that "private initiative" is adequate only for the laborer and the consumer, some degree of governmental intervention being still necessary for the capitalist and the manufacturer.

The truth is indeed that the best traditions of the United States, the real "spirit of this government," are wholly in favor of whatever governmental activity may be necessary to assure that fundamental equality of opportunity which is indispensable to true liberty and the very essence of democracy. Without such equality of opportunity, "individual initiative" is no more than a sanctimonious phrase that tastes sweet in the mouths of the 


\section{AN EXPERIMENT IN DEMOCRACY}

fortunate. And if it was proper to equalize opportunity and well-being by furnishing the people with free land and free schools, it is proper to equalize opportunity and well-being by assuring an equitable distribution among the people of that wealth which is the product of their labor and of the resources of the country which belongs to them.

If this can be satisfactorily done by "governmental intervention," the propriety of attempting it is scarcely to be questioned. But it is well to remember that governmental intervention may be quite legitimate without being quite adequate; and recent events have made it abundantly clear that the problem which confronts us is not one involving industrial liberty only, but political liberty as well. If, therefore, industrial liberty is to be achieved through the action of a beneficent government, we need to be quite sure that the government is beneficent; if the state is to give us equality, we need to know whether it is likely, in the process, to deprive us of liberty. The modern problem, which seems so largely economic, does in fact raise the political question in its most fundamental form. For many years it has been obvious that the eighteenth-century philosophy has been a complete failure on its economic side, and hitherto we have more or less confidently 


\section{THE UNITED STATES}

sought a new solution of industrial democracy within the framework of the old revolutionary political mechanism. To-day this confidence is much diminished; and it seems questionable indeed whether democracy in any form, industrial or political, does not involve a radical modification of the modern state rather than an extension of its already overgrown powers.

The modern state still rests, ostensibly, upon the revolutionary doctrine of natural rights and the popular will, and still functions, ostensibly, through the revolutionary representative mechanism. That the government should be responsive to the popular will is indeed still loudly proclaimed; but it is significant that those aspects of the revolutionary political philosophy which are most in evidence, which are indeed in the way of becoming sacrosanct, are precisely those devices for determining and expressing the will of the people which no longer do adequately determine or express the will of the people. These devices are the suffrage and the election, by majority vote, of representatives apportioned on the basis of population within definite and more or less arbitrary territorial areas. The will of the people is thus identified with the will of the majority, irrespective of the questions to be decided by the majority or of the 


\section{AN EXPERIMENT IN DEMOCRACY}

composition of the groups which make the majority and the minority in any given case.

Generally speaking, majority rule is a practicable device for determining the will of the people only under two essential conditions. The first of these conditions is that the matter about which the decision is to be binding on all should be one which it is generally agreed should be decided in one way for all. Few people believe in majority rule in respect to religious practices, and no one believes in majority rule in respect to the color of neckties. Other things equal, majority rule works well in respect to any line of conduct in proportion as the people concerned are agreed that it is a matter calling for a common decision. The second condition, closely connected with the first, is that the group or community within which the rule of the majority is to be applied should possess a high degree of solidarity. In a group in which all have much the same possessions, standards of life, and moral prepossessions, majority rule works well enough precisely because the ideas and interests of the minority are not so radically different from those of the majority that they cannot readily submit to the decision of the majority. The will of the people is sufficiently expressed by the will of the majority only when the minority "wills" to let it go 


\section{THE UNITED STATES}

at that. But when the minority is a more or less fixed group, whose ideas and interests are radically different from those of the majority, or are thought to be so, then majority rule ceases to be "government by the people" and becomes the oppression of one group by another.

Now the industrial revolution has brought about a situation in these respects to which the old mechanism of representation is. becoming unsuited. The old mechanism of representation was based upon the assumption precisely that, given free thought, free schools, and free contract, inequalities within the electorate would tend to disappear; it was supposed that the "people" would more and more be shaped, by the operation of these "liberties," to a common type in respect to material conditions, spiritual aspirations, and civic ideals. It need scarcely be pointed out that this has not proved to be the case. In place of nations of individuals, all more or less alike in respect to conditions and ideas, the industrial revolution has given us nations differentiated into classes and corporate and occupational groups, more or less different and often sharply antagonistic; and the lines of division have little or nothing to do with the territorial areas upon which political representation is based. 


\section{AN EXPERIMENT IN DEMOCRACY}

Inevitably, therefore, when a given economic group finds its interests inadequately represented within the political framework it endeavors to get its interests "represented" outside of it -it forms an organization based upon its economic interests and uses its economic power, if it has any, to exert extrapolitical pressure. The most striking examples of this phenomenon are of course the activities for many years past of the capitalist and labor groups. In 1917, when the labor-unions threatened to tie up all the railroads of the country, many people said that it was an "outrage" that the representatives of the unions should be allowed to "dictate" to the government of the United States. These people conveniently forgot that for a quarter of a century the capitalist and manufacturing groups had been sending their "representatives" to Washington, where they also "dictated," more urbanely no doubt, to the government of the United States. That either group, laborers or capitalists, should "dictate" the policy of the government is an "outrage," if you like, although no more so in the one case than in the other. But it is useless to cry "outrage." What has to be faced is a situation in which the government finds it necessary to submit to dictation by special groups; and this situation arises, in 


\section{THE UNITED STATES}

part at least, from the fact that our political machinery is no longer well adapted to our economic organization. The government, nominally composed of persons chosen to represent the will of the people in certain territorial areas, finds that the crucial problems of the time cannot be solved without taking into account the will of the people grouped in certain economic categories. This is doubtless the real source of the diminished state of Congressmen and Senators. What they too often legally represent is a group of people without any definite common will to be expressed; what they have to deal with are groups of people who can get their will expressed only by using their extra-legal economic power as a means of dictation.

Such dictation is not new; what is new is that the labor groups have recently acquired sufficient economic power to compete with the capitalist groups for the control of the government. If labor dictation seems more revolutionary than capitalist dictation, the reason is that whereas labor is dissatisfied with the present political and economic régime, capital has been and is desirous of maintaining the present political and economic régime. It is manifestly to the interest of the capitalist groups, in whose hands the industrial revolution has placed such tremendous power, to 


\section{AN EXPERIMENT IN DEMOCRACY}

maintain the capitalist régime at home, and to promote, through imperialist methods, their interests abroad. Professing unlimited faith in democracy and the rule of the majority, they are, therefore, above all others interested in maintaining unimpaired the fiction of national solidarity, and above all others interested in magnifying the state and in divesting it of responsibility both at home and abroad. In view of the persistent rivalry of nations with one another in a world of international anarchy, the prevailing nationalist psychology makes it relatively easy to identify the will of the dominant group with the will of the "people," and the interest of the dominant group with the "honor" or the "vital interest" of the nation. Confronted always with the menace of war and conquest, the disposition is always strong, and in times of crisis becomes irresistible, to place the "honor" and the "vital interest" of the nation unreservedly in the hands of the government and to assume that the government speaks for an undifferentiated nation. In the last analysis truth and virtue become indistinguishable from "loyalty"- loyalty to the government and submission to the state.

Thus on the basis of popular sovereignty and national independence, in origin a protest against the divine right of kings, there $\downarrow$ 


\section{THE UNITED STATES}

has been erected in our day the doctrine of the divine right of the state and the absolutism of the majority. To-day this absolutism is at the disposal of the capitalist class; to-morrow it may be at the disposal of the proletariat. The danger is much the same in either case. What the dominant class, whether labor or capital, really fears is not a government which either obtains or destroys liberty; what it fears is an all-powerful government which it does not control; what it desires is an allpowerful government which can be used primarily in the service of its own interests. A genuine friend of mankind, one who estimates civilization in terms of the spiritual as well as the material life, has little to hope for from the conception of an absolute state for which obedience is the only virtue and force the only test of right. Such a state, failing to effect a genuine reconciliation of contending interests and aspirations, seems destined to be a mere instrument in the hands of self-seeking groups engaged in a desolating class conflict.

"The autocracy of individuals," says Professor Pollard, "is something of a myth, and the real enemy of civilization, as it is the real parent of militarism, is the autocracy of the state, which is not confined to the Central Empires and their allies. This is also the truth about irresponsibility. The irrespon- 


\section{AN EXPERIMENT:IN DEMOCRACY}

sibility of monarchs to their peoples is a matter of detail compared with the irresponsibility of the state. If the state can do what it likes, frame its own code of international conduct, and dictate its own conception of truth and morals, it is immaterial to those who suffer whether that dictation comes from a despot or a democracy." These are words which may well give us pause. It is indeed questionable whether "industrial liberty," or liberty in any sense, can be achieved through the activities of a state which, on the assumption that it speaks for a majority, can frame its own code of international conduct and dictate its own conception of truth and morals. Democracy under these conditions is scarcely the kind of democracy the world needs to be made safe for.

Prediction is hazardous; but it would seem that the Great War has carried most European countries beyond the reasonable hope of solving the industrial problem by a mere extension of governmental intervention and the elaboration of bureaucratic supervision. To-day, at all events, the insurgent cry for the right of "life, liberty, and the pursuit of happiness" calls for something more than a little humanitarian mitigation of the present order. The trend of thought and action in Europe reveals little disposition to magnify the state or to increase the powers of govern- 


\section{THE UNITED STATES}

ment. The significance of the present movement in the labor world, such as the activities of the "triple alliance" in England or of the railroad brotherhoods in the United States, the significance of the soviet idea in all its varied forms, is that these are attempts to get the "will:" of real economic groups "represented" in government; and in so far they imply a modification of the system of representation on the basis of territorial areas. But such schemes imply far more than a mere modification of the system of political representation; they imply a more democratic control of industrial enterprise by the people directly concerned in such enterprise, and that implies in turn a restriction of direct control, not only by the capitalist class, but by the government itself. These tentative efforts may indeed prove futile; but in so far as they point the way to the future they indicate the gradual dissolution of capitalistic autocracy in industry and the decentralization of its political counterpart, the consolidated nationalist state.

The concentration of economic power in the hands of a class, the more or less effective control of the state by this class, the rationalization of the state so controlled on some foundation of divine right or of papal or popular infallibility-these are indeed old enemies of human welfare. They have appeared in every 


\section{AN EXPERIMENT IN DEMOCRACY}

stage of history, and the latter-day result of the political and industrial revolutions of the last two centuries have been chiefly to present them in new forms. That these old enemies have taken on the protective coloring of democracy makes them no less real, but only more insidious. To mistake the form for the substance of democracy, to assume with complacence that institutions under which liberties were once won will always guarantee themthis will be, for any people in the twentieth century, to court disaster. It is perhaps the peculiar danger of the United States. The time for national complacency is past. The sentimentalism which turns away from facts to feed on platitudes, the provincialism which fears ideas and plays at politics in the spirit of the gambler or the amateur, will no longer serve. The time has come when the people of the United States must bring all their intelligence and all their idealism to the consideration of the subtler realities of human relations, as they have formerly to the much simpler realities of material existence: this at least they must do if America is to be in the future what it has been in the past-a fruitful experiment in democracy.

\section{THE END}





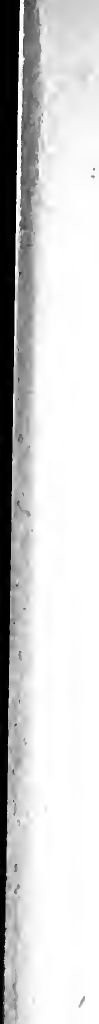





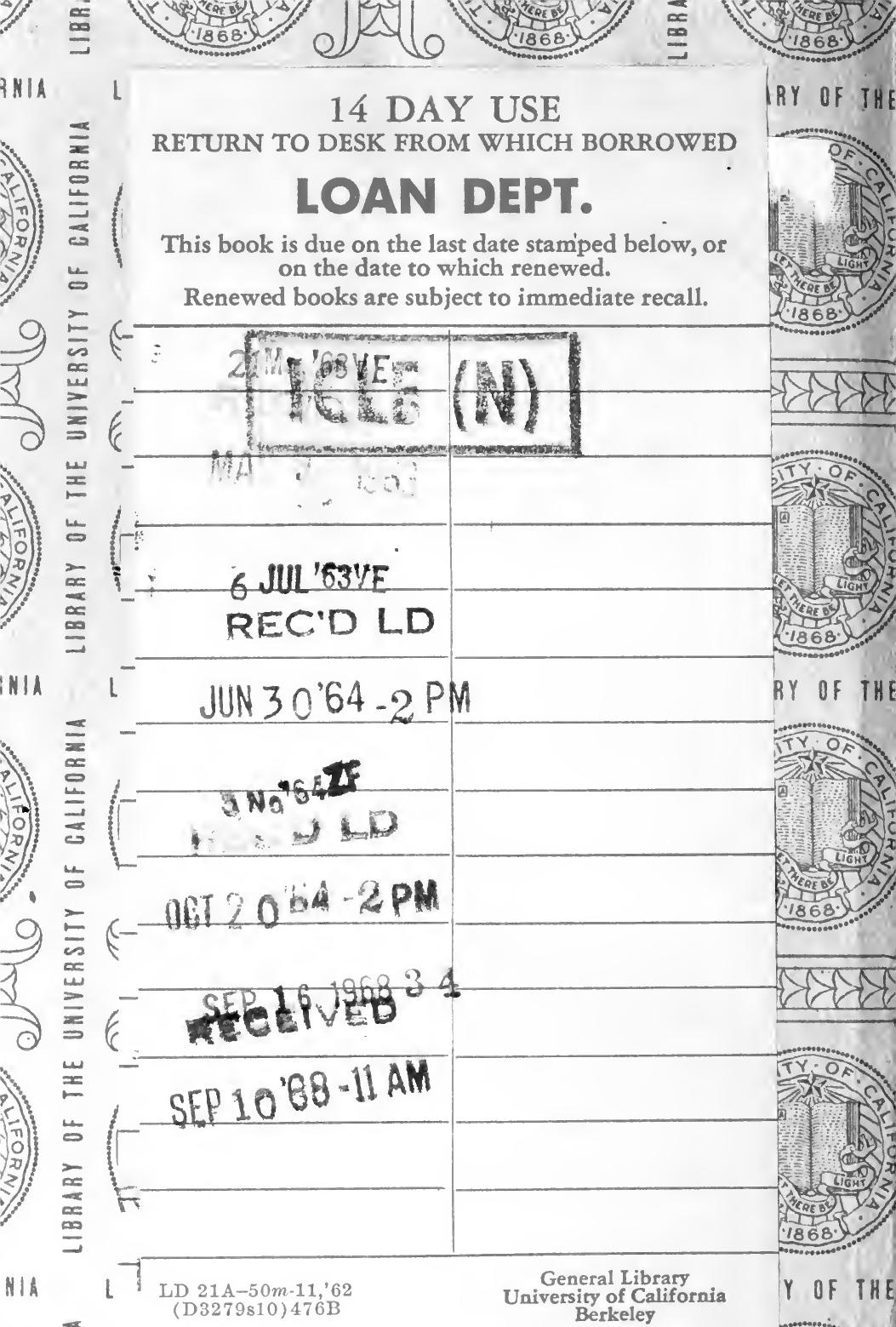

(D 3279 s10) 476B University of California
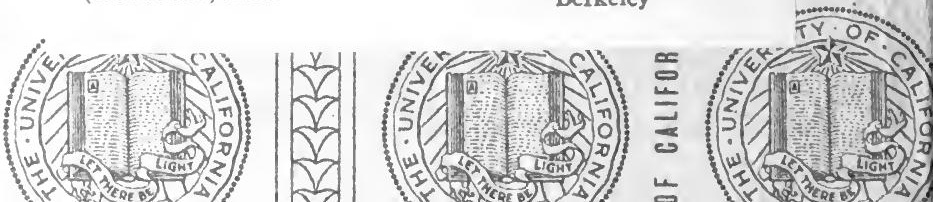

